Universidade de São Paulo

Faculdade de Saúde Pública

\title{
Rede em Saúde Mental: perspectivas e encontros rumo a redes vivas
}

\section{EMMANUELA MENDES AMORIM}

Tese de Doutorado apresentada ao Programa de Pós-graduação em Saúde Pública da Faculdade de Saúde Pública da USP para obtenção do título de Doutora em Ciências.

Área de Concentração: Prática de Saúde Pública

Orientadora: Dra. Laura Camargo Macruz Feuerwerker

\section{São Paulo}




\section{Rede em Saúde Mental: perspectivas e encontros rumo a redes vivas}

\section{EMMANUELA MENDES AMORIM}

Tese de Doutorado apresentada ao Programa de Pós-graduação em Saúde Pública da Faculdade de Saúde Pública da USP para obtenção do título de Doutora em Ciências.

Área de Concentração: Prática de Saúde Pública

Orientadora: Dra. Laura Camargo Macruz Feuerwerker

\section{São Paulo}


Para meu pai Rubem Luiz de Amorim (In memorian), estranho no ninho, que foi para outros territórios, mas deixou uma semente: o estranhar provoca outros voos possíveis. Para meus amados voinho Arlindo Bezerra de Lima (In memorian) e voinha Theresinha Mendes de Lima (In memorian), cuja dor da saudade provocou um giro no meu coração que busca nessa Tese minha melhor homenagem.

Para minha filha Yara Amorim de Farias, que me provoca revisitar um devir brincante que faz borrar traçados rumo à vida.

A escrita dessa Tese, que marca um processo de idas-e-vindas rumo a redes em saúde mental, começou pela dedicatória. Eles me ensinaram: As águas que trazem a dor do parto e a dor da partida, também são aquelas do mar que leva o barco à procura de outros mares. 


\section{AGRADECIMENTOS}

Agradeço a essa Força que-não-sei-o-que-é ${ }^{1}$, sei que inspira-respira-transpira; é luscofusco, dispara um palpitar do coração, está nas asas de um sorriso, primavera no enlace em um beijo, veraneia no calor do abraço, e cintila no pôr do sol misturando as cores...Não sei precisar, só sei sentir.

Agradeço imensamente a minha mãe Maria de Lourdes Mendes Amorim, mulher guerreira que sempre trouxe para os filhos o amor pelos estudos. Até hoje minha mais remota imagem de minha mãe é ela me ensinando a ler numa cartilha azul com figuras, letras, que passaram a ser palavras! Meu amor pelo estudo começou com ela.

Na minha trajetória tive uma "fada madrinha", uma pessoa que sempre me apoio em todos os momentos, sempre acreditou em mim e me apoiou. Obrigada, amada Tia Lúcia. E também a João Pereira, seu companheiro de jornada.

Agradeço a meu amor, pai da minha filha, minha Felixidade (!), que continua um "x" na minha cartografia. Obrigada, Félix Severino de Farias Júnior.

Minha vida se encheu de luz tornando a trajetória mais leve com meu amado irmão Leandro Luiz de Amorim, que acabou me levando a Renata Bahia Amorim e às amadas sobrinhas Ceci Bahia Amorim e Nina Bahia Amorim. Meus Domingos são mais leves com eles.

Não conseguiria desbravar São Paulo, em concretos armado e friezas, sem a fraternidade da querida família nômade Mariana Bertol Leal, Liu Leal e Silvia Cipriano. Elas desbravaram São Paulo e promoveram bons encontros.

\footnotetext{
${ }^{1}$ Nota de Rodapé em agradecimentos é uma provocação e convite para contrução de intertextualidades entre quem escreve e quem lê. É uma provocação no sentido de interferir no leitor o movimento de buscar, de tangenciar um conceito-ferramenta para a práxis em saúde. É apostar em pistas, traços que provoquem o agir ético-estético-político. Assim a primeira nota de rodapé em agradecimentos vem em um neologismo relacionado a sinal gráfico em forma de um pequeno traço horizontal, empregado para ligar os elementos de palavras compostas, separar sílabas no final das linhas e unir um verbo a pronomes enclíticos ou mesoclíticos; risca de união, traço de união, tirete. gráfico em forma de um pequeno traço horizontal, empregado para ligar os elementos de palavras compostas, separar sílabas no final das linhas e unir um verbo a pronomes enclíticos ou mesoclíticos; risca de união, traço de união, tirete. Assim já nos agradecimentos, o primeiro recurso de nota de rodapé e uso de hífen é uma aposta-provocação do tangenciar e abrir outras possibilidades de conexão para a produção de conhecimento.
} 
Também fico feliz ao ter sido acolhida e cuidada pelos queridos irmãos-amigos Ricardo Soares e Daniela Lopes, e pelo pequeno príncipe Davi nas minhas jornadas.

Aos queridos Mateus, Ana Cristina, Mari Leite, Helô, Paula, Maria das Graçastão fraternos nessa jornada de formação na FSP/USP.

Não teria dado uma reviravolta em mim mesma se não fosse Laura, pessoa sagaz na nas articulações teóricas ao mesmo tempo com a leveza e precisão da praticidade. Laura, com seus cabelos vermelhos e saltos altos, vai carregando conceitos-provocações e desterritorializando a(s) gente(s). Ela me levou para a Pesquisa Nacional que carinhosamente chamamos de Rede de Avaliação Compartilhada (RAC), um acontecimento para meus caminhos de pesquisadora.

Também me inundei de vida por estar pesquisadora IN-mundo com Raquel Rodrigues na RAC-PEBA Petrolina-Juazeiro. Obrigada pelo compartilhar desse desbravar do sertão.

Meus caminhos em Recife foram potentes quando Brena Leite e Elisângela Vasconcelis cruzaram seus caminhos com os meus para conformar o grupo RAC Recife. Com elas também forjamos o grupo RAC Recife: Emerson, Ana Carolina, Flaviano, Nathália, Rafael, Ednalva, Ariana, Aline.

Construímos encontros potentes na RAC Ariano Suassuna PB-PE: Luciano, Adriana, Ricardo, Juliana, Adely, Michelly, Marcos, Dilma, Cariri. Agradeço a tod@s!

Minha rede em Recife foi potente com o apoio de Domício Sá, Coordenador do Programa de Residência em Saúde Coletiva CPqAM/Fiocruz; Gustavo Dantas Coordenação Residência Multiprofissional em Saúde Coletiva SESAU; Carla Novais, Coordenadora do Programa de Residência em Psiquiatria SESAU.

Agradeço à Secretaria de Saúde de Recife, em especial a Telma Melo, Coordenadora de Saúde Mental, a Secretaria Executiva de Gestão do Trabalho e Educação em Saúde, em especial a Juliana Dantas; à Gerência de Atenção Básica SESAU. Aoa trabalhadores, coordenadores e usuários dos serviços de saúde que me acolheram.

Agradeço aos professores e servidores da Faculdade de Saúde Pública (FPS/USP). 
Meu muito obrigada aos professores que participaram da Banca de Defesa desta Tese: Emerson Merhy, por potencializar encontros potentes rumo a redes vivas e por sua inteligência acolhedora provoca tangenciar de redes e pessoas; Solange L'Abbate, querida professora que fez arte desse meu trajeto de formação, implicada com a Brasilidade da Análise Institucional que tanto vem contribuindo com o SUS; Lumena Furtado, estudiosa e militante do SUS, provoca encontros potentes e inusitados "no chão de fabrica" do SUS e foi generosa ao dedicar seu "olhar vibrátil" para esses escritos. 
APRESENTAÇÃO

INTRODUÇÃO $\quad 15$

Alguns pontos prévios a considerar a importância de Redes em Saúde Mental 17

no Brasil e em Recife/PE

Por que estudo de Redes em Saúde Mental? $\quad 20$

2. OBJETIVOS 38

Objetivo geral $\quad 38$

Objetivos Específicos $\quad 38$

3. MÉTODO: um convite ao traço da Cartografia 39

Um lugar para olhar, sentir, pensar: "olho vibrátil” do cartógrafo 42

Instrumentos e procedimentos da caixa de ferramentas para traçados 43 cartográficos

No meio do caminho havia uma "Rede de Avaliação Compartilhada" 46

fabricando dispositivo "usuário-guia", "redes vivas", "pesquisa interferência"

Alguns apontamentos prévios sobre o método dessa pesquisa 49

ENQUADRILÁTERO: A EDUCAÇÃO PERMANENTE EM SAÚDE COMO 51

ESTRATÉGIA DE ENCONTROS QUE TECEM REDES VIVAS

Primeiro ponto: a pesquisadora RAC Brincante em Cartografia de Rede em 57

Saúde

Misturando os pontos no plano do encontro: misturando as RAC Recife

Enquadrilátero: a RAC Aranha da Educação Permanente tecendo redes vivas REDES E RUAS: QUADRAS PARA ENCONTROS EM REDES VIVAS DE/NA GENTE

Primeiro ponto: a pesquisadora rumo às ruas com encanto pelo nômade e 65 com terror da violência contra quem está à margem

Consultório NA Rua e Consultório DE Rua em Recife/PE: pontos e arranjos politico-assistencial

Consultório NA-DE Rua: (des)encontros na/em rede 
TERRITÓRIO DE MORTE-VIDA

DESENHOS TECNOASSISTENCIAL: PROVOCAÇÕES E APOSTAS 113 RUMO A REDES VIVAS

De Modelo a Desenho Tecnoassistencial

Desenhos tecnoassistenciais: perspectivas em tensionamento

Pirâmide, Círculo e Rede: delineando potência em redes vivas

126

CONSIDERAÇÕES FINAIS

134

10 REFERÊNCIAS BIBLIOGRÁFICAS

136

Anexos

148

Parecer Comitê de Ética FSP/USP Plataforma Brasil

149 
CAPS Centros de Atenção Psicossocial

CAPS I Centros de Atenção Psicossocial I

CAPS II Centros de Atenção Psicossocial II

CAPS III Centros de Atenção Psicossocial III

CAPSi Centros de Atenção Psicossocial infantil

CAPS ad Centros de Atenção Psicossocial Álcool e outras drogas

CEO Centros de Especialidades Odontológicas

CIB Comissão Intergestora Bipartite

CID Código Internacional das Doenças

CIT Comissão Intergestora Tripartite

DMP-USP Departamento de Medicina Preventiva da Universidade de São Paulo

DS Distrito Sanitário

DSTs/Aids Doenças Sexualmente Transmissíveis/Aquired Inmodificiency Sindrome

DSM Diagnóstico de Saúde Mental

ESB Equipes de Saúde Bucal

ESF Equipes de Saúde da Família

LAPA/Uni Laboratório de Práticas de Saúde/Universidade Estadual de Campinas camp

NASF Núcleo de Atenção à Saúde da Família

OPAS Organização Panamericana de Saúde 
PACS Programa de Agentes Comunitários de Saúde

RAS Redes de Atenção à Saúde

RENASES Relação Nacional de Ações e Serviços de Saúde

RENAME Relação Nacional de Medicamentos Essenciais

RPA Regiões Político-Administrativas

RT Residências Terapêuticas

SAMU Serviço de Atendimento Móvel de Urgência

SILOS Sistemas Locais de Saúde

SRT Serviço Residencial Terapêutico

USF Unidades de Saúde da Família 


\section{RESUMO}

Redes de Atenção em Saúde Mental configuram um objeto complexo no campo da saúde e um desafio por requerer a integração e cooperação entre diferentes serviços e dispositivos para alcançar a saúde integral dos diferentes sujeitos. Configura-se, assim, em relevante objeto de investigação. Destaca-se que em uma rede de atenção integral em saúde mental diferentes pontos de vistas Objetivo geral da pesquisa: analisar a Rede de Atenção em Saúde Mental a partir de diferentes perspectivas. Objetivos específicos: Entender como se constrói um cuidado integral para portadores de transtornos mentais a partir de uma perspectiva de Rede de Atenção Integral, considerando diferentes perspectivas da Micropolitica do Cuidado em Saúde. Metodologia: Estudo qualitativo com base na cartografia. Foram realizadas observação do cotidiano dos serviços escolhidos; pesquisa documental; escrita de Diário Institucional; entrevistas e grupos focais com gestores, trabalhadores e usuários; construção de dispositivo "usuário-guia". O campo ocorreu de 2015 a 2016. A pesquisa teve aprovação no Comitê de Ética e Pesquisa da FSP/USP. Para análise foram acessados conceitos de redes vivas; relação instituinte-instituido-institucionalização; molar-molecular-linha de fuga, usuário-guia. Resultados: diante das vivências e afetos construídas no encontro entre diferentes pessoas que participam do cuidado em saúde, aposta-se na construção de Desenhos Tecnoassistenciais a partir de uma perspectiva micropolitca. Tais desenhos são fabricados na potência do encontro entre diferentes perspectivas e olhares para a construção do cuidado no cotidiano das ações e serviços de saúde. Considerações finais: Espera-se que o debate em torno dos Desenhos Tecnoassistencias a partir do encontro que transversalize diferentes perspectivas, sendo reconhecida a linha de cuidado como um desenho vivo forjado na interação entre diferets forças molares e moleculares que operam o cotidiano micropolítico das ações e serviços de saúde.

Palavras-chaves: Saúde Mental; Rede em Saúde Mental; Micropolitica do Cuidado em Saúde. 


\begin{abstract}
Care Networks in Mental Health configure a complex object in the field of health and a challenge requiring integration and cooperation between different services and devices to achieve comprehensive health of different subjects. It is configured thus in relevant investigated. It is noteworthy that in a network of comprehensive mental health care different viewpoints general objective of the research: to analyze the Care Network for Mental Health from different perspectives. Specific objectives: Understanding how to build a comprehensive care for people with mental disorders from a Comprehensive Care Network perspective, considering different perspectives of micropolitics of Health Care. Methodology: Qualitative study based on cartography. observation of the daily life of the chosen services were performed; documentary research; writing Institutional Journal; interviews and focus groups with managers, workers and users; "User guide" device construction. The field was 2015 to 2016. The research was approved by the Ethics and Research Committee of FSP / USP. For analysis were accessed concepts of living networks; instituing-instituted-institutionalization relationship; molar-molecularline leakage, user guide. Results: on the experiences and emotions built in the encounter between different people involved in health care, bet on the construction drawings Technical healthcare from a micropolitca perspective. Such drawings are made in the power of the meeting between different perspectives and looks to the care construction in the daily actions and health services. Final Thoughts: It is expected that the debate on Tecnoassistencias Drawings from the meeting that transversalize different perspectives, care line is recognized as a living drawing forged in the interaction between diferets molar and molecular forces operating the micropolitical everyday actions and health services.
\end{abstract}

Keywords: Mental Health; Network Mental Health; Micropolitics of Health Care. 


\section{APRESENTAÇÃO}

Esse estudo buscou compreender Rede de Atenção em Saúde Mental considerando diferentes perspectivas de quem constrói o cuidado. Nesse sentido, buscou entender se/ e como se constrói um cuidado integral para portadores de transtornos mentais a partir de uma perspectiva de Rede de Atenção Integral em Saúde Mental considerando diferentes perspectivas de quem constrói o cuidado. Para tanto se apoiou na micropolitica do cuidado em saúde e no método Cartográfico e fez uso de dispositivos conceituais como redes vivas, interferência, o encontro enquanto método, usuário-guia, tensão entre forças molar-molecular e deslocamentos em linha de fuga, instituinte-instituído-institucionalização.

$\mathrm{Na}$ introdução é apresentado o trajeto da pesquisadora para a construção do objeto de estudo. Busca-se situar esse objeto considerando sua importância no campo da política de saúde no Brasil, sobretudo as redes em saúde mental como estratégicas para a construção de um cuidado integral. Também se apontam os questionamentos construídos que orientaram os caminhos percorridos nesse pesquisa.

Em seguida, destacam-se objetivo geral e específicos desse estudo.

Em terceiro lugar, é discutido o método da cartografia que orientou os rumos dessa pesquisa situando sua relação com o objeto redes em saúde, relacionado ao campo micropolítico.

Na quarta parte, a Educação Permanente em Saúde é apresentada enquanto estratégia para mobilizar o encontro entre diferentes pessoas e perspectivas para o estudo de redes vivas em saúde. É apresentado então o Enquadrilátero e RAC-Aranha enquanto conceito-neologismo para compreensão e ação (práxis) no campo da saúde.

Na quinta parte é debatida a vivência de e nas redes forjadas nas ruas, no cuidado a pessoas em situação de rua, a partir de serviços como Consultório NA Rua e Consultório DE Rua. 
Em sexto lugar, pondera-se sobre o processo de fabricar o cuidado em rede viva em saúde, envolvendo diferentes perspectivas e afetos. É apresentado o possesso de cuidado em rede para uma pessoa em situação de rua. Pedro, que de "planta" ou "pedra", provoca deslocamentos dos diferentes olhares nas tantas jogadas de xadrez da vida.

A sétima parte aborda o processo de produção de encontro com Maria, que mesmo com a devastação da morte-vida, vai construindo caminhos possíveis para a vida. Redes Vivas são possíveis na articulação entre CAPS e ESF enquanto território inter-relacional e, Maria vai além desses serviços pela potência do acontecimento.

A oitava parte traz uma virada conceitual: de Modelo de Atenção à Saúde investe-se na reflexão para Desenhos Tecnoassistenciais a partir de uma perspectiva micropolitca. Aposta-se na potência do encontro entre diferentes perspectivas para a construção do cuidado no cotidiano das ações e serviços de saúde. Faz-se uma articulação entre conceitos de molar-molecular enquanto forças micropolíticas que operam Desenhos Tecnoassistencias. Nesse correlação de forças micropolíticas é possível a produção de linhas de cuidado que operem tecnologias leves-duras e leveduras a partir de uma rede viva, do entrecruzar de olhares em tensão entre molarmolecular.

Por fim, são apresentadas as considerações finais e anexos. 


\section{INTRODUÇÃO}

\section{Chão}

\section{Lenine/Lula Queiroga}

Chão chega perto do céu

Quando você levanta a cabeça e tira o chapéu

Chão cabe na minha mão

O pequeno latifúndio do seu coração

Chão quando quer descer

Faz uma ladeira

Chão quando quer crescer

Vira cordilheira

Chão segue debaixo do mar

$\mathrm{O}$ assoalho da planeta e do terceiro andar

Chão onde a vista alcançar

Todo e qualquer caminho pra percorrer e chegar Chão quando quer sumir se esconde em um buraco

Chão Se quer sacudir

Vira um terremoto

O chão quando foge dos pés

Tudo perde a gravidade

Então ficaremos só nós

A um palmo do chão da cidade

Prelúdio. sm (lat praeludiu) 1 Ato ou exercício preliminar. 2 Introdução, preâmbulo, prefácio, prólogo. 3 O que anuncia, o que precede; prenúncio; sinal ou indício de coisa que há de acontecer; precursor. 4 Mús Introdução instrumental ou orquestral de uma obra musical, podendo ser absolutamente independente e não ter caráter introdutório: Prelúdio de Chopin. 5 Mús Ensaio da voz ou de um instrumento antes de cantar ou tocar. Antôn: poslúdio. (Michaelis, Dicionário OnLine). 
O exercício de escrever uma tese acadêmica é também paralelamente um exercício meta analítico envolvido na produção de conhecimento nos moldes científicos. Nesse sentido, sempre se buscará refletir que a análise para uma tese deve seguir determinados moldes acadêmicos. Buscar-se-á, ao mesmo tempo, refletir sobre o objeto e o ato de "tesear", neologismo que representa o verbo do fazer da escrita de uma tese.

Ao mesmo tempo também se buscará uma linguagem acadêmica com intercessões com outras linguagens para ampliar a capacidade de comunicar a significação em torno do objeto analisado. Nesse sentido, alí e acolá no texto desta pesquisa, aparecerão algumas poesias, músicas, fotografias, cordéis ou outras formas que ajudem a qualificar a reflexão em torno do objeto pesquisado - "processamento de tese". Por se tratar de uma perspectiva em que a Rede Viva se produz no encontro e negociação com outros, vale a pena lançar mão de várias formas de expressão.

Esse texto inicial, pré-texto da tese, busca partir de uma leveza na escrita. Um prelúdio que ganha contornos de "prélúdico", neologismo que busca integrar o prelúdio ao universo lúdico. Não se pretende aqui desconsiderando a importância da construção de uma tese, mas pretende-se adotar uma postura lúdica dessa construção. Ou seja, entende-se que o lúdico ensina a criança, que não tem medo do desconhecido, pelo contrário, o desconhecido é instigante por empolgar os sentidos, a motricidade e assim vai forjando o pensamento. Assim, pensei que essa trajetória de construção poderia ter a leveza de minha forma de andar no mundo, uma forma brincante, que busca o riso do cômico e a leveza do andar nômade, do riso como uma saída potente para as amarguras do viver e do pesquisar. O riso como potente escondido no enigmático sorriso da Monalisa, do riso como produção singular da humanidade tão brilhantemente exposto em "O nome da Rosa”, de Humberto Eco.

Enquanto aprendiz de pesquisadora questiono se tal estudo acadêmico contribuirá para a ciência e como. Claro que passada a qualificação da tese, parto de uma questão e objeto pertinente para o conhecimento na Saúde Coletiva. Mas é prudente levantar a relevância desse tipo de estudo. Revisitar os questionamentos e afinar os conceitos-ferramentas é um exercício inicial prudente e estratégico para qualificar a postura do cientista rumo à produção do conhecimento. Tal como um músico que sempre afina seu instrumento para ensaiar e ensaiar, para depois se 
apresentar, também buscarei uma atitude de questionar se o que faço e farei é mesmo científico e singular. Dito isso, parto então de uma questão: o que é Rede de Saúde Mental em Recife/PE a partir de múltiplos olhares - gestor, trabalhador, usuário e familiar? Partindo dessa pergunta, constrói-se uma aproximação com o campo e com o objeto.

Depois de tantos caminhos em perspectiva nômade, voltei ao Recife/PE em 2013 - "foi a saudade que me trouxe pelo braço" (Frevo de Luiz Bandeira). Iniciar essa reflexão com um frevo, música típica de Pernambuco, abre caminho para um afeto pelas artes de um povo. Lembra o carnaval que arrasta multidões aos sons dos clarins do raiar dos dias de carnaval, das cores, sons, suor coletivo pulsando, frevo...ferver...ebulição de gentes pulsando nas ruas de um lugar.

Retorno com afeto pelo lugar e pelas pessoas e venho carregando uma caixa de ferramentas repleta de conceitos-ferramentas, potenciais artefatos-conceituais que ajudem a construir uma tese inovadora.

Voltei e estranhei a cidade "da lama ao caos" (Chico Science e Nação Zumbi). A cidade está cada vez mais vertical por tantos arranha-céus e por tanta desigualdade social que distancia as pessoas. Recife é mais lenta também na mobilidade, que a eleva ao posto da cidade com mais engarrafamentos no Brasil.

Recife. Por que esse nome? No dicionário, recife é substantivo masculino que significa rochedo ou série de rochedos à flor da água, que fica próximo às costas. Existem os recifes de corais, composição de seres vivos pequeninos, que é responsável por grande e importante ecossistema marinho. E quem for para Recife, capital do estado de Pernambuco/Brasil, vai perceber que esse nome tem tudo a ver com o território que lhe é característico.

Mas não só a água do mar compõe o quadro da cidade. Recife é entranhado de rios e mangues. Ah, os mangues! Na Biologia o termo Ecótone é denominação de uma zona de transição entre dois ecossistemas. E o mangue é um écotone, um ecossistema costeiro de transição entre ambientes terrestre e marinho, uma zona úmida característica de regiões tropicais e subtropicais. Recife é então um lugar movediço caracterizado pelo mangue e é também espaço de transição, elementos muito bem figurados na canção 
"rios, pontes e overdrives, impressionantes esculturas de lama”, música emblemática do Movimento Mangue Beat. Esse movimento também retrata a cidade que vai "da lama ao caos" onde "o de cima sobe e o de baixo desce".

Mas o caos não é um fenômeno negativo em si. Caos também é uma imagem emblemática por desalojar o instituído. A própria “Teoria do Big Bang”, que afirma que o universo provavelmente nasceu de uma explosão (Paradigma da Física), traz um elemento importante para esta argumentação. O desorganizar instituinte talvez traga a potência para algo novo.

Voltando para Recife como "cidade da lama ao caos", destaca-se que para transitar na cidade temos as pontes, que levam as pessoas para diferentes territórios. As pontes são estruturas do "entre", que unem os territórios. "E como é que faz para sair da ilha? Pela ponte. Pela Ponte. A ponte não é para ir ou pra voltar. A ponte é somente atravessar. Caminhar nas águas desse momento" (A ponte. Música Lenine).

Transitar é movimentar, é deslocar de um lado para outro e é em busca desse deslocamento de diferentes lugares, considerados em sua diferença, mas potente em seu ir-e-vir, movimento que essa pesquisa busca focar, por possibilitar a construção de redes vivas.

Essa pesquisa busca a construção de conhecimento a partir de diferentes perspectivas. Há a perspectiva da pesquisadora, cujas implicações apresentadas aqui nesse texto, mas que também vai emergir no encontro com o campo de pesquisa. Implicações que emergem pelo seu afeto e afetação em torno do lugar Recife, de recifes, mangues e pontes. Mas ao mesmo tempo busca outros olhares para tornar potente o objeto complexo por ser multifacetado. (ponto de vista e vista do ponto)

Parte-se de um lugar de pesquisadora que tem em sua caixa de ferramentas conceitos da Análise Institucional e da Saúde Coletiva, ao mesmo tempo em que admite que o encontro com o campo de pesquisa necessariamente vai ser atravessado por diferentes perspectivas, que vai colocar em questão esse lugar. Essa postura de pesquisadora é como a de um pintor de quadros de arte que tem em sua paleta cores primárias (conceitos), mas que, ao pintar um quadro, vai misturando uma cor em outra e forma uma terceira cor e junta essa a outra cor e vai trazendo outros matizes para 
configurar um quadro. A obra vai ganhando vida e até ultrapassa o criador tal como a "Mona Lisa" de Leonardo da Vinci ou "Os Girassóis" de Vincet van Gogh,. O autor fica apenas com sua assinatura no canto da obra gigantesca em suas provocações de significações.

Outra analogia importante para compor essa argumentação está no campo da Biologia: o DNA enquanto elemento base para a reprodução da vida. As bases do DNA são adenina, citosina, guanina e timina e delas quatro ocorre a reprodução da vida ${ }^{2}$, desde pequenos microorganismos, até mesmo grandes viventes como os dinossauros de outras épocas, e até o ser humano, até então o único animal pensante. Mas há no homem algo extraordinário, o pensamento. Pelo pensamento se construiu a reflexão sobre o DNA e pela ciência foram criadas estratégias para fundamentar tal teoria.

O modo de refletir do cientista é mesmo intrigante. É muito importante ir e vir com de um olhar, escutar e pensar mais desterritorializado para que se produza um "terreno fértil" para novas ideias. Darwin em suas viagens para Galápagos ficou tão intrigado com animais diferentes em suas pequenas diferenças territoriais. Ou seja, ao visitar várias ilhas percebeu o cientista que havia pequenas diferenças no corpo de uma espécie. Interpretou Darwin que essas diferenças ajudariam na adaptação em cada região. Foi então que oque acabou forjando a "Origem das espécies", paradigma da Biologia.

Trazendo essas reflexões para o contexto dessa pesquisa ora apresentada, será adotada a perspectiva da Cartografia enquanto guia para aguçar o ver, sentir e agir, elementos provocadores e intrínsecos ao pensar. Quando se evocam várias linguagens (quadros, músicas, poesias, cordéis e outros) para compor o argumento dessa tese, é justamente para se articular de modo significativo e singular com conceitos da Análise Institucional e Saúde Coletiva para analisar Rede em Saúde Mental.

Nesse ponto surge a pergunta: A produção que emergirá nessa tese será reproduzida em outros espaços para além de um município, Recife (princípio da reprodução no campo da ciência). Volta-se para a imagem: Redes Vivas são como os corais de recifes. Recentemente descobri que a maior estrutura visível do espaço sideral

\footnotetext{
${ }^{2}$ Excetua-se dessa perspectiva o vírus, que não se enquadra nessa conceituação pois os mesmos necessitam de outros seres para se reproduzirem e até então vários vem ocorrendo em torno deles; elementos que fogem ao nosso atual debate.
} 
é uma região de $\operatorname{corais}^{3}$ (!). Corais são estruturas vivas formadas pelo DNA de quatro elementos, e se forjam sem planejamento de tal maneira que até podem ser vistos do espaço sideral. Como algo tão frágil pode ser ao mesmo tempo grandioso e se tornar referências para a produção de um ecossistema tão monumental?

Fazer ciência é construir uma tese com algumas ferramentas-conceitos. É até mesmo inventar outras ferramentas-conceitos para explicar determinado fenômeno ao mesmo tempo em que busca contribuir, de alguma forma, a produção de conhecimento. Assim me lanço ao mar, ao mangue, aos recifes de possibilidades dessa Rede Viva que possa forjar uma Rede de "Saúde" Mental.

Mas antes do lançar-se ao caminhar rumo a "redes em saúde mental" pode apostar em alguns apontamentos prévios no movimento de (re) visitar algumas considerações sobre a pertinência desse objeto a ser apresentado nessa Tese.

\section{Alguns pontos prévios a considerar a importância de Redes em Saúde Mental no Brasil e em Recife/PE}

Há uma intensa disputa em torno dos modos de produzir cuidado aos portadores de transtornos mentais. Na perspectiva da Luta Antimanicomial, destacam-se algumas lutas e conquistas: a III Conferência Nacional de Saúde Mental representou um importante espaço de encontro de diferentes sujeitos e de formulação de prerrogativas e estratégias de ação para reorientação e melhoria da atenção a essas pessoas peculiares, que culminou na proposição de um relatório que é base para a política atualmente vigente. No mesmo sentido, a Lei 10.216, de 06 de abril de 2001 (Brasil, 2001), conhecida como "Lei Paulo Delgado", que preconiza o fim dos manicômios, sobretudo com a estratégia de realocar os recursos antes destinados à internação nos manicômios para serviços substitutivos aos asilos e também regulamentou a internação psiquiátrica compulsória. Outro destaque é Lei n. ${ }^{\circ} 10.708$ de 31 de julho de 2003 (Brasil, 2003), que institui o auxílio reabilitação para pacientes egressos de internações psiquiátricas, denominado “De Volta Para Casa”. E por último é importante destacar a Portaria 336/02

\footnotetext{
${ }^{3}$ Discovery Science. A grande Barreira de Corais. Aborda a grande barreira de corais, a maior estrutura do mundo. Uma verdadeira orquestra de viventes que pode também ser uma analogia para a imagem do rizoma.
} 
(Brasil, 2002), incorporando os avanços na condução de alguns dos equipamentos substitutivos: os Centros de Atenção Psicossocial/CAPS (Brasil, 2001, 2002, 2004a; 2004b).

Dentro desse contexto, preconiza-se que o cuidado ao portador de transtorno mental deve ser construído em Rede de Cuidado sendo pertinente destacar os recentes marcos legais referentes a esse objeto. O Decreto Presidencial $N^{\circ} 7.508$, de 28 de junho de 2011 (Brasil, 2011a), que regulamenta a Lei no 8.080, de 19 de setembro de 1990 e dispõe sobre a organização do Sistema Único de Saúde/SUS, o planejamento e a assistência à saúde e a articulação interfederativa. Preconiza elementos organizativos da Rede como Região de Saúde, Contrato Organizativo da Ação Pública da Saúde, Portas de Entrada, Comissões Intergestores, Mapa da Saúde, Rede de Atenção à Saúde, Serviços Especiais de Acesso Aberto, Protocolo Clínico e Diretriz Terapêutica, que serão explicados a seguir:

- Região de Saúde: refere-se ao espaço geográfico contínuo constituído por agrupamentos de Municípios limítrofes, delimitado a partir de identidades culturais, econômicas e sociais e de redes de comunicação e infraestrutura de transportes compartilhados, com a finalidade de integrar a organização, o planejamento e a execução de ações e serviços de saúde. Cada região de saúde dever contemplar no mínimo dos seguintes componentes: I-atenção primária; IIurgência e emergência; III-atenção psicossocial; IV-atenção ambulatorial especializada e hospitalar; e V- vigilância em saúde.

- Contrato Organizativo da Ação Pública da Saúde: diz respeito ao acordo de colaboração firmado entre entes federativos com a finalidade de organizar e integrar as ações e serviços de saúde na rede regionalizada e hierarquizada, com definição de responsabilidades, indicadores e metas de saúde, critérios de avaliação de desempenho, recursos financeiros que serão disponibilizados, forma de controle e fiscalização de sua execução e demais elementos necessários à implementação integrada das ações e serviços de saúde;

- Portas de Entrada: referindo-se aos serviços de atendimento inicial à saúde do usuário no SUS; que devem ser construídos a partir da Saúde da Família, organizados de forma hierarquizada nos seguintes componentes: I- de atenção primária; II-de atenção de urgência e emergência; III-de atenção psicossocial; e 
IV-especiais de acesso aberto, sendo que o ordenador da rede e do acesso deve ser estruturado a partir da Atenção Primária,

- Comissões Intergestores: são as instâncias de pactuação consensual entre os entes federativos para definição das regras da gestão compartilhada do SUS. Elas já existiam (CIB e CIT), mas ganham um aspecto de estruturação enquanto instância de pactuação para a conformação de redes regionalizadas.

- Mapa da Saúde: é a descrição geográfica da distribuição de recursos humanos e de ações e serviços de saúde ofertados pelo SUS e pela iniciativa privada, considerando-se a capacidade instalada existente, os investimentos e o desempenho aferido a partir dos indicadores de saúde do sistema;

- Rede de Atenção à Saúde: diz respeito ao conjunto de ações e serviços de saúde articulados em níveis de complexidade crescente, com a finalidade de garantir a integralidade da assistência à saúde. Para tanto, a referida Portaria aponta para instrumentos de organização da Rede de Atenção a Relação Nacional de Ações e Serviços de Saúde/RENASES, que são as ações e serviços que o SUS oferece ao usuário para atendimento da integralidade da assistência à saúde; e a Relação Nacional de Medicamentos Essenciais/RENAME, que se refere à seleção e a padronização de medicamentos indicados para atendimento de doenças ou de agravos no âmbito do SUS. Os protocolos Clínicos também orientam a dinâmica da Rede de Atenção à Saúde.

- Serviços Especiais de Acesso Aberto: são os serviços de saúde específicos para o atendimento da pessoa que, em razão de agravo ou de situação laboral, necessita de atendimento especial; e

- Protocolo Clínico e Diretriz Terapêutica: é o documento que estabelece: critérios para o diagnóstico da doença ou do agravo à saúde; o tratamento preconizado, com os medicamentos e demais produtos apropriados, quando couber; as posologias recomendadas; os mecanismos de controle clínico; e o acompanhamento e a verificação dos resultados terapêuticos, a serem seguidos pelos gestores do SUS.

No âmbito da atual Política Nacional de Saúde Mental, a Portaria 3.088, de 27 de dezembro de 2011 (Brasil, 2011b), institui a Rede de Atenção Psicossocial como referencia para o cuidado à "pessoa com sofrimento ou transtorno mental e com 
necessidades decorrentes do uso de crack, álcool e outras drogas, no âmbito do SUS". Enfatiza que a rede deve ser organizada em serviços de base territorial e comunitária, com a participação e controle social dos usuários e seus familiares. Deve também garantir a articulação e integração dos pontos das redes de saúde no território, qualificando o cuidado por meio do acolhimento, do acompanhamento contínuo e da atenção às urgências.

No que se refere aos componentes da Rede de Atenção Psicossocial, ela deve ser composta por Atenção Básica em Saúde; Atenção Psicossocial Especializada; Atenção de Urgência e de Emergência, atenção residencial de caráter transitório; atenção hospitalar; estratégias de desinstitucionalização e reabilitação psicossocial. Tais componentes são definidos a seguir:

- Atenção Básica: Unidade básica de saúde; equipe de atenção básica, identificando equipes de consultório de rua e equipes de referencia para os Serviços ligados ao Componente Residencial Terapêutico; Centro de Convivência;

- Centro de Atenção Psicossocial/CAPS: podem ser CAPS I, II, III, CAPSi, CAPS ad, a depender do tamanho da população do município e da construção da Rede desse território.

- Atenção à urgência e emergência: há a unidade de acolhimento, que é um ponto de atenção que oferece cuidados contínuos para usuários que necessite. Mas destaca-se que não se trata de leito psiquiátrico, pois se determina que o tempo de permanência deva ser de, no máximo, seis meses. Os Serviços de atenção em regime residencial, dentre as quais as comunidades terapêuticas, devem estar articuladas com os CAPS.

- Serviços hospitalares: devem estruturar as enfermaria com equipe especializada em atenção às pessoas em sofrimento mental intenso. Deve estar articulada com hospital geral, que deve garantir uma equipe multiprofissional especializada nesse tipo de atendimento. 
A referida legislação também preconiza que se deve garantir geração de trabalho e renda/empreendimentos solidários e com cooperativas sociais. Essa legislação é complementada por outras portarias

- Portaria 3.089, de 23 de dezembro de 2011, republicada em 30 de dezembro de 2012, e institui o teto financeiro fixo para os CAPS (Brasil, 2011c).

- Portaria 121, de 25 de janeiro de 2012, que institui a unidade de acolhimento para pessoas com necessidades decorrentes do uso de Crack, álcool e outras drogas (Unidade de Acolhimento) (Brasil, 2012a).

- Portaria 123, de 25 de janeiro de 2012, define os critérios de cálculo do número máximo de equipes de Consultório na Rua por Município. (Brasil, 2012 b)

- Portaria 130, de 26 de janeiro de 2012, que redefine o centro de atenção psicossocial de álcool e outras drogas 24 horas (Brasil, 2012c).

- Portaria 131, de 26 de janeiro de 2012, que institui o incentivo financeiro ao custeio nos Estados, Munícipios e Distrito federal para o custeio de Serviços de Atenção em Regime Residencial, incluindo comunidades terapêuticas, voltados a pessoas com necessidades decorrentes do uso de Crack, álcool e outras drogas (Brasil, 2012 d).

- Portaria 132, de 26 de janeiro de 2012, que institui incentivo financeiro para o custeio da rede de atenção psicossocial (Brasil, 2012e).

Destaca-se que construção dessas redes depende da articulação entre os atores sociais que estão em seus territórios. Nesse sentido, pode-se refletir que cada local (estados e municípios) pode assumir diferentes modelagens (Braga Campos, 2000) ou configurar arranjos específicos (Campos, 2000a, 200b) em virtude de suas diferenças sociais e políticas. $\mathrm{O}$ mesmo autor considera que essas devem ser fundamentadas por meio de dispositivos ou de composições de arranjos. Explica então que dispositivo é uma montagem ou artifício produtor de inovações, que gera acontecimentos, atualiza virtualidades e inventa o "novo Radical” (Baremblitt, 2002).

Considerando-se essas especificidades territoriais, é importante situar o porquê de estudar a conformação de rede de atenção em saúde mental em Recife/PE. assim, é importante situar que Política Municipal de Saúde Mental em Recife/PE é uma temática 
abordada de forma sistemática no Plano Municipal de Saúde Recife de 2006-2009 (Recife, 2006) e no Plano Municipal de Saúde de Recife 2010/2013 (Recife, 2010), documentos que apontam para a necessidade de consolidação do "Modelo de Atenção à Saúde Mental”. Além desses referenciais, destaca-se também o Relatório da $9^{\text {a }}$ Conferencia Municipal de Saúde de Recife/PE. A seguir serão apresentados alguns pontos principais para ajudar na compreensão de como se configura a Rede de Saúde Mental em Recife/PE, no contexto do que se preconiza enquanto política de saúde.

Recife/PE apresenta uma composição territorial diversificada: morros - 67,43\%, planícies - 23,26\%, áreas aquáticas - 9,31\%, Zonas Especiais de Preservação Ambiental (ZEPA) - 5,58\%. A cidade está dividida em 94 bairros distribuídos em seis Regiões Político-Administrativas (RPA). Para o setor de saúde, cada RPA corresponde a um Distrito Sanitário - DS, totalizando seis DS (Recife, 2010):

Atualmente o município é considerado totalmente urbano com uma população de aproximadamente 1.634 .808 em 2010. A cidade é ocupada por uma população predominantemente jovem: $35,58 \%$ de população com faixa etária entre 30 e 59 anos e $28,87 \%$ de 15 a 29 anos.

Mas é importante situar o cenário em que a cidade se estruturou no que se refere à sua rede de saúde. Assim, destaca-se que, em 2001, o município apresentava baixa densidade de sua rede de atenção à saúde e grande parte dos atendimentos era realizada em unidades de saúde estaduais, bem como havia baixa cobertura da Saúde da Família (27 equipes representando 5,02\% de cobertura), do Programa de Agentes Comunitários de Saúde/PACS (45\%) e os então 46 Centros de Saúde, chamados de "Unidades Básicas Tradicionais" no Relatório Municipal de Saúde de Recife 2010-2013, atuavam com baixa resolutividade. Havia a persistência de importantes endemias como filariose, tuberculose e hanseníase.

A partir de 2001, o município implantou o "Modelo de Atenção Municípios Saudáveis", ampliando a cobertura de Saúde da Família, criando e implantando o Programa "Academia da Cidade", com a realização de atividades de educação física nas praças e espaços públicos do município, implantou o Programa de Saúde Ambiental, com 100\% de cobertura dos Agentes de Saúde Ambiental; implantou o Tratamento Coletivo de Filariose e estabeleceu importantes parâmetros de controle do vetor da 
doença; criou e estruturou o Serviço de Atendimento Móvel de Urgência (SAMU), estruturou a Diretoria Geral de Gestão do Trabalho para redefinir a relação com os trabalhadores para garantir direitos trabalhistas e realização de concurso público; estruturação da Assistência Farmacêutica com a criação do Programa Farmácia da Família; criou o Ambiente Livre do Fumo; ampliou ações em saúde objetivando a diminuição da mortalidade infantil; e iniciou o debate para a municipalização dos serviços estaduais no território de Recife/PE.

De 2001 a 2008, o município implantou 213 Equipes de Saúde da Família-ESF, 113 Equipes de Saúde Bucal-ESB, 24 Urgências Odontológicas 24h, 04 Centros de Especialidades Odontológicas-CEO; 10 "Centros de Apoio Psicossocial- CAPS"; 06 CAPS Álcool/Drogas; 11 Residências Terapêuticas-RT.

As referências para o Plano Municipal de Saúde de Recife 2010/2013 são as "Diretrizes do Recife em Defesa da Vida" (Recife, 2010): valorização da atenção básica com a capacidade para solucionar problemas individuais e coletivos; ampliação das ações de promoção e prevenção; rearticulação dos serviços de alta complexidade e especializados, segundo padrões de humanização e adoção de outras práticas em saúde como a internação domiciliar, visita aberta e direito à acompanhante de livre escolha do usuário em sua internação hospitalar; estabelecimento de atenção à saúde segundo linha de cuidado com equipes de referência e cogestão; necessidade da desinstitucionalização da saúde mental e do trabalho transdisciplinar para elaboração de projetos terapêuticos com resolutividade. Por fim, situa-se que essas "experiências e mudanças de conceitos e práticas oferecem alguns elementos para que se construa uma teoria sobre o processo de saúde-doença centralmente preocupada com a produção de saúde e de sujeitos”.

Destacam-se compromissos ético-políticos do referido da "Defesa da Vida" enquanto modo de funcionamento da rede de saúde: qualificar o sistema de cogestão, a partir de do princípio democrático reconhecendo a responsabilidade de cada ator no processo de gestão do sistema e na produção de saúde; criar um sistema de saúde em rede, que supere o isolamento dos serviços em níveis de atenção; fortalecer e qualificar a atenção básica e ampliá-la como estratégia organizadora das redes em saúde; fortalecer o processo de regionalização cooperativa e solidária, ampliando o acesso com equidade; considerar a diversidade cultural e desigualdade econômica, assim como a característica epidemiológica para incorporação de recursos e tecnologia/ superar 
fragmentação do processo de trabalho e das relações entre os profissionais; implantar diretrizes do acolhimento e clínica ampliada; melhorar a interação entre as equipes de saúde e qualifica-las para lidarem com as singularidades os sujeitos nas práticas de atenção em saúde. E por fím, destaca-se que a Saúde da Família é apontada nesse documento como ordenadora da assistência em saúde e deve ser responsáveis por diferentes ações em saúde da população.

No que se refere à saúde mental, que deve se articular com a Saúde da Família, o documento destaca que existem os Centros de Atenção Psicossocial-CAPS, Residências Terapêuticas e Albergues Terapêuticos, serviços que visam a redução da internação psiquiátrica. Destaca-se a redução do número de internações SUS, que era de 17.370 em 2000, para 1.300, em 2008. Neste mesmo período registrou-se o aumento do número de procedimentos nos CAPS de 9.069 para 96.445 (Recife, 2010).

Para acompanhamento de alcoolistas, tabagistas e dependentes químicos apontase a parceria entre CAPS ad, equipes da Saúde da Família com o Programa "Mais Vida", que trabalha com a proposta da redução de danos, buscando diminuir os efeitos negativos do consumo do álcool, fumo e outras drogas e a Politica de Controle do Tabagismo, que proporciona o tratamento do tabagismo simultaneamente ao uso do álcool e outras drogas nos CAPS ad e Albergues Terapêuticos.

Com relação à Rede de Atenção em Saúde Mental, destaca-se que a cidade apresentou rápida expansão nos serviços em saúde mental. Em 2010, contava com 18 CAPS e 11 Residências Terapêuticas, porém ainda faltava organizar os serviços em rede, no que se refere aos fluxos assistenciais e práticas de trabalho. Para tanto, apontava-se para a necessidade de ação integrada com vários setores do município, como assistência social, educação e direitos humanos, e de articulação com o governo estadual, sobretudo no que se refere a implantação de leitos breves em hospital geral e redução de leitos psiquiátricos.

Algumas ações foram indicadas para a estruturação da Rede de Saúde Mental:

- Implantar um equipamento municipal como uma das portas de entrada de emergência psiquiátrica 
- Desenvolver uma politica intersetorial para implantação de empregos protegidos para pessoas com transtornos mentais;

- Programação de formação continuada para os profissionais de saúde, educação e assistência social;

- Construir uma proposta de implantação de leitos breves em conjunto com a Secretaria Estadual de Saúde SES-PE;

- Criar indicadores de Reabilitação Psicossocial para avaliação para avaliação e monitoramento das ações nos Serviços Residenciais Terapêuticos e nos CAPS;

- Implantar a atuação no SAMU na intervenção de casos graves de transtornos mentais em decorrência do uso de drogas, como retaguarda do atendimento préhospitalar;

- Realizar mapeamento epidemiológico, por Distrito Sanitário, para usuários com transtornos mentais em decorrência do uso de álcool e outras drogas e, sobretudo avaliar as áreas cobertas por PSF e PACS;

- Implantar Centros de Convivência;

- Garantir espaços de gestão colegiada (cogestão) com discussão de casos integrados com profissionais de CAPS e PSF/PACS

- Transformar CAPS Livremente, CAPS José Carlos Souto e CAPS Galdino Loreto e um CAPS no DSIII em CAPS 24h;

- Criação de Grupo de Trabalho para discussão integral ao transtorno mental na infância e adolescência.

Outro documento que referencia a política de Saúde Mental em Recife/PE é o Relatório Final da $9^{\text {a }}$ Conferência Municipal de Saúde do Recife/PE, realizada de 06 a 08 de Outubro de 2009, que preconiza a necessidade de Consolidar o "Modelo de Atenção à Saúde", denominado "Modelo de Atenção à Saúde Mental/Programa + Vida - Redução de Danos no consumo de álcool e outras drogas" ". A seguir, apontam-se as diretrizes para essa política (itens 71 a 111 do referido relatório):

\footnotetext{
${ }^{4}$ Em capítulos seguintes, no percorrer dessa pesquisa acabou-se chegando a serviços como Consultório DE Rua e Consultório NA Rua que existem na Rede de Atenção Psicossocial (RAPS) em Recife que "provocam" essa RAPS para o cuidado integral como analisadores da potência ou não dessa rede.
} 
71. Fortalecer, ampliar e garantir o fluxo de referências dentro dos DS para atender as crianças e adolescentes em tratamento nos CAPS de Saúde Mental e Mais Vida, garantindo o acompanhamento ambulatorial e na atenção básica.

72. Definir uma política que garanta o acesso ao tratamento dos usuários dos CAPS, albergues terapêuticos e residências terapêuticas, integrando as secretarias de promoção social para buscar alternativas de acessibilidade dos usuários.

73. Implantar o prontuário eletrônico em toda a rede municipal.

74. Aumentar cota para especialidades: CAPS AD, psiquiatria, exames laboratoriais e consultas em todas as Policlínicas, agilizando as marcações das mesmas;

75. Garantir de profissionais qualificados para lidar com os usuários e familiares nos CAPS e serviços residenciais terapêuticos, através de formação continuada.

76. Promover ações de sensibilização e divulgação junto à comunidade, enfocando os jovens sobre redução de danos e prevenção ao uso de álcool e outras drogas, com ênfase na abordagem do tabagismo e crack junto ao governo municipal e estadual;

77. Realizar ações de redução de danos e prevenção ao uso de drogas no território, com a construção de fluxos de ações junto aos CAPS e Equipes de Saúde da Família.

78. Criar indicadores de Reabilitação Psicossocial para avaliação e monitoramento das ações nos Serviços Residenciais Terapêuticos e nos CAPS;

79. Publicizar a Lei 10.216/2001através dos meios de comunicação disponíveis, divulgando os direitos das pessoas com transtorno mental;

80. Inserir profissional de nível superior com especialização comprovada em Arteterapia nos CAPS;

81. Garantir espaços de gestão compartilhada (cogestão) através de discussão de casos integrada com os profissionais dos CAPS e as equipes do Programa Saúde Família e PACS para o atendimento dos usuários com transtorno mental e com transtorno em decorrência do uso de álcool e outras drogas do território, (fóruns microrregionais e distritais com as políticas estratégicas para discussão das linhas de cuidado);

82. Reativar fóruns de discussão em saúde mental e estabelecer uma periodicidade mensal em todos os distritos sanitários;

83. Garantir o acolhimento/atendimento de usuários com transtorno mental e transtorno em decorrência do uso de álcool e outras drogas nos SPA - Serviços de Pronto Atendimento das Policlínicas;

84. Requalificação dos CAPS através de processos de educação permanente do quadro de RH e de supervisão institucional dos trabalhos do CAPS. 
85. Transformar o CAPSi em CAPSi 24horas;

86. Transformar os CAPS Espaço Vida, CAPS Livremente, CAPS José Carlos Souto e o CAPS Galdino Loreto em CAPS 24 horas.

87. Garantir a equipe mínima dos CAPS e qualificação da mesma

88. Implantação de CAPS AD para crianças e adolescentes usuárias de álcool e outras drogas no DS VI e no DS III, incluindo um albergue;

89. Implantar uma porta de entrada municipal para urgência/emergência psiquiátrica, pautada no "modelo do serviço substitutivo".

90. Garantir e estabelecer prazo para a redução dos leitos psiquiátricos de acordo com os princípios da Lei 10216/2001 concomitante com o processo de qualificação/monitoramento sistemático dos equipamentos substitutivos existentes.

91. Melhorar a estrutura dos CAPS com recomposição plena das equipes de Saúde Mental.

92. Implantação de um CAPS infantil nos Distritos onde não existe este serviço com a contratação de psiquiatra infantil

93. Garantir e intensificar o acompanhamento dos pacientes de alta do CAPS no ambulatório e pela equipe PSF no território;

94. Implantar nas Equipes de Saúde da Família o acolhimento dos usuários de transtorno Mental e de usuários de Álcool e outras Drogas;

95. Construir Centro de Convivência de múltiplo uso (reabilitação psicossocial, atividades culturais, arte-educação, socialização) aproveitando espaços já existentes em até 05 anos.

96. Ampliar equipe de retaguarda/ação avançada em todo o DS para saúde mental;

97. Criar mais residências terapêuticas;

98. Incluir profissional farmacêutico em todos os CAPS de acordo com a exigência da Portaria MS no 344.

99. Desenvolver formação continuada para toda equipe multiprofissional da Saúde Mental para cuidados em saúde mental de forma intersetorial;

100. Ampliar e qualificar a atuação do SAMU na intervenção nos casos graves de transtorno mental e transtorno em decorrência do uso de drogas garantindo o atendimento da urgência.

101. Realizar mapeamento epidemiológico no distrito sanitário para usuários identificados com transtornos mentais e transtornos decorrentes do uso de álcool e outras drogas, com levantamento da prevalência do uso abusivo/dependência. Adequar 
Projetos terapêuticos Singulares para atendimento da demanda de Saúde Mental e do Programa + Vida;

103. Incluir as ações educativas voltadas para prevenção do uso de drogas nas escolas municipais, através do Programa de Saúde nas Escolas;

104. Garantir a supervisão clínico-institucional para equipes nos serviços de CAPS, CAPS AD, Centro de referência para mulheres usuárias de drogas e nas Casas do Meio do Caminho (Albergue Terapêutico) e Residências Terapêuticas;

105. Garantir atividades de reinserção social (oficinas de geração de renda com arte educador retorno aos estudos, participação em cursos profissionalizantes) para os usuários transtorno mental e os usuários de álcool e outras drogas;

106. Desenvolver uma política intersetorial para implantação de empregos protegidos para pessoas com transtornos mentais;

107. Garantir como direito adquirido a prescrição de medicamentos especiais para pessoas com transtorno mental;

108. Garantir que os CAPS AD permaneçam como ambiente livre do Fumo;

109. Ampliar o número de vagas para os usuários em tratamento e o número de profissionais nos albergues terapêuticos;

110. Fortalecer ações intersetoriais de Prevenção ao uso de álcool e outras drogas;

111. Implantar uma política de reabilitação no município.

Apresentar esses elementos auxilia na reflexão para situar o lugar que se construiu o estudo, pois foi desses elementos que se construiu a importanxcia do objeto a ser estudado. Entretanto, vários desses elementos foram tensionados no processo da pesquisa diante de algumas inquietações no decorrer da pesquisa e que serão apresentadas nos capítulos seguintes. Mas antes de se chegar aos próximos capítulos, é importante ressaltar alguns questionamentos que serviram de provocação para desterritorializar o olhar da pesquisadora em torno de seu objeto.

Assim, se uma introdução de uma Tese tem o compromisso de uma aposta de considerações sobre um determinado objeto como um elemento de importância para a construção de conhecimento, aponta-se que essa primeira parte é um prelúdio enquanto convite à reflexão e/ou mobilização rumo a redes vivas. 


\section{Por que estudo de Redes em Saúde Mental?}

O modo como se organizam os serviços é forjado pelo atravessamento de disputas políticas e, no cenário dos serviços em saúde mental, há alguns debates importantes que se articulam a disputas no modo de produção do cuidado a pessoas com transtornos mentais

Ao longo do tempo e das diferentes sociedades, foram diferentes os conceitos e os modos de conviver com os "loucos". A partir do Iluminismo e até Reforma Psiquiátrica, acreditava-se que a doença mental estava atrelada à ideia da periculosidade, uma vez os "loucos" ameaçariam a ordem social, pautada no ideal do homem moderno regido pela razão (Foucault, 2006, 2010, 2009, Machado, 2006). Com essa perspectiva, produziu-se uma assistência que buscava "a cura" dessa "doença", sob responsabilidade dos hospitais psiquiátricos, estabelecimentos de tutela dos "alienados" (Amarante, 1995, 1996; Torre e Amarante, 2001). Esses elementos, à luz da Análise Institucional, caracterizariam os elementos instituídos do processo de institucionalização da doença mental e sua assistência.

Com o tempo e com intensos debates técnico-científicos e políticos, foi sendo desconstruído esse conceito, já que os manicômios ofereciam farta evidência de que o afastamento do convívio social e a violência, relacionados ao processo de institucionalização, produziam agravamento dos sintomas. Assim, seria preciso construir outra lógica de atenção que se fundamentasse no contrato entre doente, terapeuta e demais membros da sociedade, pois é nos lastro das relações sociais que se constrói um contexto de melhores possibilidades para essas pessoas peculiares em seu modo de estar no mundo. Nesse sentido, essa nova perspectiva substitui a ideia de cura pela construção de uma corresponsabilidade dos indivíduos e coletivos, apontando para um cuidado sustentado por uma Rede Social, elementos instituintes da doença mental e sua assistência.

Um dos pontos importantes dessa nova perspectiva de cuidado a portadores de transtornos mentais, que caracteriza a Reforma Psiquiátrica, está na reflexão de que o cuidado a portadores de transtornos mentais se faz a partir de uma Rede de Cuidado, estratégia também presente nas bases da Reforma Sanitária. Dessa forma, uma rede de 
serviços que prestem uma assistência integral ao sujeito é capaz de atender as várias e complexas demandas que surgem nos serviços de saúde e por isso é preciso construir uma articulação: entre os diferentes trabalhadores de um serviço, entre os diferentes serviços, entre esses essa rede de saúde com aquelas da promoção de ações intersetoriais, entre as unidades de saúde e os diferentes equipamentos sociais. Em resumo, para se promover um cuidado integral é preciso propiciar o encontro entre as várias organizações em saúde e vários outros equipamentos sociais.

Os estabelecimentos de saúde mental foram importantes para a produção do Movimento Institucionalista, uma vez que vários de seus pensadores também buscavam interpretar os fenômenos que ocorriam nesses lugares. Entretanto, deve-se esclarecer que esse movimento possui várias correntes, cada uma com suas especificidades: a Psicoterapia Institucional, a Pedagogia Institucional, a Psicossociologia e Análise Institucional (Lourau, 1975). Essas tinham como ponto comum uma redefinição do conceito de instituição, pois negavam a concepção durkheimiana que as interpretava como imutáveis (Moura, 1995, 2003; Altoé, 2004). Nesse texto a ênfase será para a Análise Institucional.

A Análise Institucional foi criada na França, na década de 1960, e reconhece-se René Lourau, Georges Lapassade e Félix Guattari como os três autores fundamentais para a estruturação da Análise Institucional como um campo de saber e prática que tem como objeto a "instituição". Nesse contexto, atribui-se a invenção do termo "Análise Institucional" a Guattari, enquanto que a construção da prática socioanalítica foi fruto de produções/atuações de Lapassade e coube a Lourau (1975) a sistematização dessa concepção teórico-metodológica (L'Abbate, 2012).

Influenciado pelas concepções sobre instituinte e instituído de Castoriadis (1982) e pelo modelo dialético de Hegel (1992), Lourau (1975) expressa que uma instituição é composta pelo movimento de três momentos: o instituído ou estabelecido, caracterizado pelo momento da universalidade; o instituinte ou acontecimento, que nega o momento instituído (anterior) e caracterizando a particularidade; e o momento da institucionalização, representando a singularidade, reflexo da articulação dialética entre os momentos anteriores, indicando um "vir a ser" (Lourau, 1975; 2006; L'Abbate, 2005).

Lourau (1975) diferencia o conceito de instituição daquele de estabelecimento ou 
organização, uma vez que estes seriam uma forma de expressão da instituição, contextualizada por meio de disciplinas, estruturadas em núcleos de saber, que orientam, por sua vez, a formulação de regras, normas e burocracias. Assim, a partir dessa perspectiva, para compreender um fenômeno que se processa em uma organização formal ou mesmo nos grupos, é importante entender o modo como se articulam esses três momentos da instituição que orienta o "caminhar" de um determinado grupo, organização ou estabelecimento.

O conceito de analisador, que corresponde a um determinado acontecimento, ou conjunto de acontecimentos, capaz de revelar aspectos que permaneciam ocultos num grupo, organização, ou até numa sociedade (Lourau, 1975). Nesse sentido, ao revelar o que estava escondido, ao desorganizar o que estava organizado, é possível abrir outras possibilidades para o caminhar do grupo ou da organização.

$\mathrm{O}$ destaque que o analisador provoca e reverbera enquanto potente para se colocar em questão elementos institucionais substitui então o papel do analista, especialista que intervém junto a grupos e organizações, uma vez que o analisador é um elemento produzido pelo próprio movimento do coletivo, atualizado em suas várias situações de análises. Nesse caso, o analisador é o "elemento-provocador", que revela as contradições da trama dos três momentos da instituição e que permite o emergir das implicações institucionais (L'Abbate, 2004; 2012). E mais, o analisador é um dispositivo capaz de fomentar mudanças, uma vez que "é o analisador que realiza a análise" (Lourau, 2004, p. 69).

O conceito de implicação se refere ao envolvimento inconsciente e sempre presente das pessoas em tudo o que fazem. De acordo com Barbier (1985), a implicação tem três dimensões: afetivo-libidinal, a existencial e a estruturo-profissional, isto é, todos somos impulsionados por nossas escolhas afetivas, ideológicas e profissionais, $\mathrm{o}$ que atravessa as nossas escolhas pelas organizações que escolhemos participar, bem como aquelas que orientam nosso caminho teórico-metodológico. Esclarece-se ainda que a 'implicação é um nó de relações; não é 'boa' (uso voluntarista) nem 'má' uso jurídico-policialesco" (Lourau, 2004a, p.190), ou seja, a implicação corresponde aos vários atravessamentos dos diferentes elementos que compõem a instituição instituídos, instituintes e em institucionalização, forjados nas diversas mutações das produções humanas, em sua dimensão universal, particular e singular. Vários estudos da 
atualidade referem esse conceito, destacando-se o de Monceau (2008). E por fim, destaca-se a inquietação da implicação, potente para impulsionar o movimento das pessoas, e nessa perspectiva aponta-se a frase de uma Nise da Silveira, militante e estudiosa do campo da Saúde Mental no Brasil, que anunciava "É necessário se espantar, se indignar e se contagiar, só assim é possível mudar a realidade...". E esse projeto busca se somar a esse movimento de pessoas implicadas em transformações inclusivas no campo da saúde mental.

Já dispositivo grupal diz respeito a elementos capazes de gerar mobilizações dos sujeitos particulares e coletivos. Nesse sentido, determinados discursos, organizações, leis, enunciados morais repercutem produzindo alterações no funcionamento de um determinado grupo ou organização, gerando efeitos como submissão, harmonização, ansiedade, dependência, emancipação, entre outros (Barros, 2004). Entender quais são esses elementos que mobilizam os agrupamentos também é uma forma de compreender os fenômenos institucionais que afetam os grupos e organizações.

Transversalidade é um conceito construído por Guattari (1987), que também é um conceito utilizado pela Análise Institucional para a compreensão da dinâmica institucional. Diz respeito aos diferentes vínculos que os sujeitos sociais constroem nas práticas institucionais e se relacionam às dimensões formais e informais que ocorrem nos agrupamentos humanos. Explicando melhor, no movimento dos grupos há elementos que expressam a verticalidade, que mediam as relações e se expressam no modo como se organizam o organograma de uma empresa, que orienta a relação entre chefes e subordinados (dimensão formal da instituição). Por outro lado, também existe a horizontalidade expressa pela dimensão informal dos agrupamentos, expressando um movimento "em que as coisas e as pessoas ajeitam-se como podem na situação em que se encontram" (Guattari, 1987, p.96). Quando os sujeitos se subjugam a essas dimensões vertical ou horizontal, têm-se grupos assujeitados, mas quando se produz um movimento desalienado/criativo de grupos-sujeito, correlacionando-se esses dois eixos, tem-se a dimensão da transversalidade. "A transversalidade é uma dimensão que pretende superar os dois impasses, o de uma pura verticalidade e o de uma simples horizontalidade; ele tende a se realizar quando a comunicação máxima se efetua entre os diferentes níveis e, sobretudo nos diferentes sentidos. É o próprio objeto da busca de um grupo sujeito" (p. 96). 
Quanto maior o coeficiente de transversalidade de um grupo, tem-se um gruposujeito potente e criativo para driblar as adversidades, superando a postura de assujeitamento presa às dimensões verticais ou horizontais das instituições. Para esse movimento de mudança o desejo é fundamental, por operar nas transformações das dimensões micropolíticas, produzindo saídas criativas.

Com relação a instrumentos da Análise institucional, aponta-se o Diário Institucional como uma "ferramenta" utilizada para o registro das impressões do pesquisador diante de seu objeto de pesquisa, que devem ser registradas de modo a descrever fatos, vivências, sentimentos surgidos durante o processo de pesquisa (Hess, 1988; Pezzato; L’Abbate, 2011).

Nesse estudo compreende-se a Rede de Atenção em Saúde Mental enquanto um objeto em institucionalização, sendo atravessado por elementos instituídos, denunciados pelo Movimento da Reforma Psiquiátrica (Brasil, 2002) e Reforma Sanitária (o poder psiquiátrico e o poder biomédico), e instituintes, que acabaram por produzir vários dispositivos presentes nas ações e serviços de saúde como a Saúde da Família e Saúde Mental na produção de um cuidado integral. Entende-se que se trata de um objeto complexo, mutante, atravessado por disputas cotidianas das políticas, sobretudo se se considera a pluralidade dos diferentes sujeitos como corresponsáveis pela implementação dessa política. Rede de Atenção em si é um caleidoscópio, formado por determinadas cores, que poderiam representar um olhar objetivo particular e singular (gestor, trabalhador, usuário, familiar), mas que na dinâmica de operacionalizar tal rede, depende de um contexto, determinado movimento e relações de forças micropolíticas, que formatam um determinado arranjo mais potente, produtor de vida, e outro não. Tal imagem do caleidoscópio é potente, pois a cada giro do movimento político, dos diferentes atores, se forja uma rede mais potente em trazer respostas mais produtoras de vida do que outro arranjo, sendo que todos os atores podem mudar de lugar e produzir arranjos mais ou menos potentes de cuidado a depender dos encontros entre gestão, trabalhadores e usuários.

Primeiro pelo ponto de vista de resgatar o debate conceitual em torno do objeto pesquisado nesse estudo dentro do campo científico. Em segundo lugar, possivelmente essas disputas do melhor organizar (ou não) a articulação dos serviços em rede, 
considerando (ou não) as diferentes perspectivas dos trabalhadores, gestores e usuários, auxiliará na reflexão e produção em torno do objeto "rede em saúde mental".

Tendo em vista esse debate amplo de estruturação de Rede de Saúde e Rede de Saúde Mental implementado em Recife há mais de uma década e tendo em vista a implicação da pesquisadora (Amorim, 2008), que é recifense, considera-se que o estudo de Rede em Saúde Mental terá elementos relevantes para ajudar a refletir sobre a Rede de Atenção em Saúde Mental.

\section{Algumas questões então marcam o objeto desse estudo:}

- É possível construir formas singulares de cuidado? Como se produz o encontro entre os diferentes sujeitos?

- Entende-se que rede conforma um cenário provocador de encontro entre os diferentes sujeitos.

- Rede traz elementos instituintes que ajudam a produzir um cuidado integral (integralidade).

- Rede é construída por sujeitos que se conectam de diferentes modos na relação do cuidado, mesmo que possuam diferentes implicações no processo do cuidado - trabalhador, gestor e usuário.

- Rede de atenção integral em saúde mental é um objeto complexo por se considerar atravessados por diferentes elementos

- Como se dá essa institucionalização de uma rede de atenção integral em saúde mental?

- Para se construir rede é importante entender como diferentes sujeitos (usuários, trabalhadores e gestores) vão tecendo (ou não) tal rede. Tal conformação também estaria atrelada a um processo de transversalidade da gestão do cuidado. 


\section{OBJETIVOS}

\section{Objetivo geral}

Analisar a Rede de Atenção em Saúde Mental no município de Recife considerando diferentes perspectivas de quem constrói o cuidado.

\section{Objetivos Específicos}

1. Entender se/ e como se constrói um cuidado integral para portadores de transtornos mentais a partir de uma perspectiva de Rede de Atenção Integral em Saúde Mental considerando diferentes perspectivas de quem constrói o cuidado. 


\title{
3. MÉTODO: um convite ao traço da Cartografia
}

\begin{abstract}
Recriando a partir do grande pensamento: "Se cheguei até aqui foi porque me apoiei no ombro dos gigantes" (Isaac Newton): Se cheguei até aqui foi porque me apoiei em ombros de gigantes, fiquei sem chão ao me desterritorializar dos pré-conceitos para cartografar uma ciência de estranhamento e criação.
\end{abstract}

"Rede em Saúde Mental a partir da perspectiva do gestor, trabalhador, usuário e familiar", eis um objeto complexo desde a sua construção enquanto objeto válido de ser investigado pela concepção científica, passando pela sua pertinência para o campo da vida das pessoas e no contexto científico e político até chegar a uma forma de investigalo - metodologia científica.

Considerando Feuerwerker e Merhy (2011), é particularmente complexo acessar a produção do cuidado que acontece em ato e depois de efetivado o pesquisador consegue encontrar apenas seus "vestígios" nos trabalhadores, nos usuários e seus familiares, cada um em sua singularidade em vivenciar o processo de assistência. A complexidade da produção do cuidado também se forja a partir de diferentes perspectivas daqueles envolvidos naquele ato, daquele que cuida e que é cuidado, com suas especificidades em seus lugares de atores do processo, e que também são atravessados em seus corpos pelas diversas instituições implicadas na operacionalização desse ato. Os referidos autores expressam que essa dimensão da produção do cuidado, por sua vez, e se expressa pobremente por meio do que está registrado em prontuários; mas a maior parte deles são impressos nos corpos envolvidos na produção do cuidado.

São várias as possibilidades de investigação ancoradas em perspectivas epistemológicas diversas e cabe ao pesquisador fazer opções mais coerentes, considerando as especificidades de seu objeto e suas filiações teóricas e ideológicas. Nesta pesquisa, pretende-se realizar um estudo qualitativo, considerando a perspectiva da análise institucional como norteadora da aproximação em torno do objeto.

Após várias tentativas de arranjos de metodologia, dinâmica expressa no Diário Institucional da pesquisadora, e considerando a implicação da mesma com o objeto a ser estudado, optou-se por um estudo cartográfico, lançando mão de diferentes 
dispositivos - instrumentos e procedimentos- para a aproximação com o objeto. Nesse caso, importante referir que a pesquisadora pretende cartografar a rede de saúde enquanto processo e encontro de diferentes subjetividades e para isso pretende utilizar ferramentas-conceitos da análise institucional para refletir e se fazer dialogar na comunidade científica, com os participantes do estudo e sociedade em geral. Acredita-se que no encontro com o objeto de estudo que serão produzidas afetações para e na pesquisadora no seu contexto de pesquisa. E por meio desses diferentes dispositivos de pesquisa da caixa de ferramentas da pesquisadora no seu "cartografar" pretende-se construir a compreensão desse objeto complexo desse estudo.

Em uma primeira perspectiva, Cartografia é um termo que tem suas origens na Geografia e corresponde ao registro das paisagens que se conformam segundo sua afetação pela natureza, pelo desenho no tempo como existência, pela vida que passa naquela paisagem. Os filósofos da filosofia da diferença, Deleuze e Guattari (2000) apreendem o termo e o desterritorializam afirmando que as paisagens sociais são cabíveis de serem cartografadas. Referem o termo mapa para descrever linhas, identidades, subjetivações da paisagem social tal como um mapa geográfico. Esses filósofos fazem um movimento de desorganizar para reorganizar o termo cartografia tal como quem desterritorializa o chão de referenciais conceituais anteriores, abrindo espaço limítrofe entre o chão duro do instituído-conceitual e a água-mole do rio, tal como o mangue é limítrofe entre o chão e o rio, ao mesmo tempo em que é berçário do vir-a-ser.

A cartografia surge no Brasil em 1989 como proposta metodológica oriunda dos estudos da filosofia da diferença, da pragmática universal e como um novo paradigma ético-estético. Suely Rolnik tem no seu livro "Cartografia Sentimental” (1989) um importante referencial que conceitua a cartografia como a conformação do desejo no campo social (Feuerwerker; Merhy, 2011).

Feuerwerker e Merhy (2011) trazem uma reflexão sobre novos processos metodológicos, fazendo uma aposta na cartografia como uma aproximação ao campo de pesquisa potente para a produção de saberes. Também ponderam que a cartografia participa e desencadeia processos de desterritorialização, é uma construção espacial subjetiva no campo da ciência para inaugurar uma nova forma de produzir conhecimento, sendo esse um terreno-território fértil que envolve a criação, a arte, a 
implicação do pesquisador/autor/cartógrafo. Parece mais uma das reflexões do movimento mangue que expressa "Posso sair daqui para me organizar Posso sair daqui para desorganizar (...). Da lama ao caos, do caos à lama Um homem roubado nunca se engana" (Nação Zumbi) aludindo ao constante movimento de construção de novos referenciais a partir da desterritorialização daquele que se propõe refletir e criar em diferentes campos de conhecimento, estando incluído, mesmo que de forma diferente, o campo científico.

Nessa concepção a cartografia é útil para descrever processos mais que o estado das coisas e por se debruçar sobre processos é que se aponta para a potência dessa abordagem metodológica. Volta-se então para entender como o objeto de estudo acontece se manifesta e não se volta ao produto ou resultados finais do trabalho. Ferigato e Carvalho (2011, p 667) acrescentam ainda que

Isso [a cartografia] nos indica um procedimento de análise a partir do qual a realidade a ser estudada está em constante transformação e movimento, uma realidade composta por diferentes narrativas, contextos e linhas de força a serem consideradas e sua complexidade e singularidade. A transformação da realidade aqui referida, também ocorre a partir do próprio observador e das referencias da pesquisa no universo real, o que implica o pesquisador com um campo problemático na transformação de si, do objeto e de seu contexto, conferindo ao trabalho da pesquisa seu caráter intrínseco de intervenção, como já indicava Lourau (2004).

O uso da Cartografia como referência metodológica para o campo científico vem sendo denominado "investigação cartográfica" (Ferigado; Carvalho, 2011). No campo da psicologia é possível citar Rolnik (2007); Do Eirado (2005), Fonseca (2007), Passos Kastrup e Escóssia (2009); Barros (2007) dentre outros. No campo da Saúde Coletiva destacam-se Merhy (2002), Teixeira (2003), Franco et al (2009), Ceccim e Feuerwerker (2004), Carvalho, Ferigato e Barros (2009), Silva et al, (2010), Feuerwerker e Merhy (2011), entre outros. 


\section{Um lugar para olhar, sentir, pensar: “olho vibrátil” do cartógrafo}

O estudo pretende ser realizado em um Distrito Sanitário, em Recife, capital do estado de Pernambuco, localizada no nordeste do Brasil. Localizada a beira-mar, a cidade "não para, a cidade só cresce, o de cima sobe e o debaixo desce" (Chico Sciense e Nação Zumbi, banda do Movimento Mangue beat da cena cultural dos anos de 1990 em Pernambuco), considerando seu complexo contexto de desigualdade social não tão diferente de muitas capitais e cidades brasileiras, mas mantendo sua singularidade no que se refere à produção cultural. Essa singularidade também se refere, por sua vez, ao modo como se construiu a Rede de Saúde Mental na cidade, elementos abordados na introdução desse projeto de pesquisa de doutorado.

A escolha do distrito onde será realizada a pesquisa ocorrerá após a aproximação da pesquisadora com o campo de prática e com o diálogo e pactuação com os gestores municipais (nível central e gestores dos serviços) em um primeiro momento e com trabalhadores, usuários e familiares em um segundo momento. Essa conversa será para apresentação do projeto de pesquisa e pactuação do desenvolvimento de suas etapas. Nesse sentido, o distrito da cidade que tiver mais movimentos e apostas na área de saúde mental será aquele onde será realizada a pesquisa. Nesse sentido a reflexão que potencializa o estudo de rede é como um quebra-cabeça em que se acredita que a quantidade de peças, que tensiona a necessidade de serem encaixadas, acaba por trazer um quadro mais amplo de diferentes peças em articulação ou um "rizoma" que se expande para vários espaços e assim apoia uma planta em vida.

Mas até a escolha desse distrito, muitos pactos irão ser firmados, desde a aprovação deste projeto no Comitê de Ética e Pesquisa da FSP/USP, que já foi submetido para apreciação desse órgão, até a pactuação com o gestor municipal e local e com os trabalhadores, gestores, usuários e seus familiares dos serviços que conformam rede de saúde mental. 


\section{Instrumentos e procedimentos da caixa de ferramentas para traçados cartográficos}

Depois de situar que a matriz propulsora desta pesquisa é a cartografia, que nesse estudo está ancorada à perspectiva da análise institucional - no sentido de que essa oferece conceitos-ferramentas para se pensar a dinâmica institucional para o processo de construção de redes em saúde mental, é imprescindível apresentar e problematizar os instrumentos e procedimentos que se pretende utilizar neste estudo. Pretende-se lançar mão de:

\section{- Construção de diário institucional}

Nesse sentido essa produção do diário já se iniciou no processo de problematização do objeto e metodologia dessa pesquisa e se dará ao longo do estudo.

\section{- Análise documental:}

Verificação de outros documentos no contato com as organizações onde será realizado o estudo tais como documentos de gestão, prontuários, livros-ata de reuniões.

\section{- Entrevistas com informantes-chave:}

É importante realizar entrevistas com informantes-chaves para conhecer a realidade dos distritos sanitários que tenham dispositivos de rede de saúde mental em maior número e com capacidade de operacionalizar a articulação desses dispositivos em rede de atenção em saúde mental. Esses entrevistados podem ser representantes de trabalhadores e entidades de usuários e familiares de saúde mental, especialistas na área, entre outros.

\section{- Observação participante}

Observação com interação e pactuação com participantes do estudo para entender como se configura os processos de construção de rede em saúde mental. Será importante, inclusive no processo de aproximação e construção compartilhada com gestores e trabalhadores, a observação do cotidiano dos processos de trabalho do cuidado em rede em saúde mental. 


\section{- Casos traçadores:}

Após ter sido definido o distrito sanitário que contemple a potencialidade de serviços de saúde mental em rede, pretende-se realizar encontros com os profissionais de saúde para que esses escolham casos representativos do perfil do serviço: casos que provocaram desconforto e casos que provocaram satisfação.

Essa escolha, por sua vez, precisa ser de forma coletiva de modo que a equipe debata em grupo o porquê da dinâmica de determinado caso ou casos ser representativa do que consideram ser "caso provocador de conforto" e "caso provocador de satisfação"

A partir das escolhas dos casos, detalhados pelas esquipes e devidamente justificados pelas equipes dessa escolha, prepara-se um relato detalhado do caso, primeiramente analisando os prontuários e os relatos dos casos. E em seguida, acompanha-se a equipe em visita à casa desses usuários ou mesmo uma escuta no próprio serviços para entrevista a esses usuários indicados e seus familiares para que os mesmo possam falar como compreenderam o tratamento realizado, os serviços que participam da assistência dessas pessoas e como fazem essa assistência.

Todo material é então estruturado em forma de narrativa e é compartilhado e discutido com as equipes de saúde. Momento que abre mais um espaço para a autoanálise da equipe de saúde. Nesse sentido, os trabalhadores que participam da eleição dos casos são aqueles que conformam (ou se pretende conformar) em rede de assistência, ou seja, pode ser que no distrito onde será realizada a pesquisa ocorra uma reunião de integração de profissionais para compartilhar determinado caso. Por exemplo, pode haver um espaço de reunião de equipe em que participem trabalhadores de CAPS, residência terapêutica, NASF para debater determinado caso ou a organização de processos de trabalho em saúde mental. Assim, uma vez que esses trabalhadores forjam um espaço de troca em seus cotidianos de trabalho é tal espaço o eleito para a realização na dinâmica do "caso traçador".

Do processo ao platô de ancoragem metodológico: Mas de onde vem esse artifício metodológico? Primeiramente de onde vem a palavra traçador, vem de traço 
Traço sm (der regressiva de rraçar $\left.^{1}\right) \mathbf{1}$ Ato ou efeito de traçar. 2 Linha traçada com lápis, pena, pincel etc.; risco. 3 Linha do rosto, lineamento; feição, fisionomia, caráter. $4 \mathrm{~A}$ linha que primeiramente marca o desenho na pintura; delineamento, esboço. 5 Impressão, rasto, sinal, vestígio. 6 Parte, passagem, trecho de discurso. 7 Acontecimento, lance, sucesso. 8 Constr Percentagem expressa em números proporcionais do peso ou volume da água, cimento, areia ou do cascalho, no preparo de argamassa ou concreto. 9 Reg (Nordeste) pop Porção de bebida tomada de uma só vez. sm 10 Inform Largura em pixels da caneta ou pincel usado para desenhar na tela. 11 Tip e Inform A grossura de um caractere impresso. T.-deunião: a) V hífen; b) por ext: aquilo que serve para ligar ou unir.

Tal alusão a traço faz evocar a ideia de leveza do processo fazendo articulação com a perspectiva de desenhos tecnoassistenciais, que se referem a configurações provisórias das práticas e das organizações vivas e singulares.

Essa estratégia metodológica é respaldada no estudo realizado por Feuerwerker e Merhy (2011) e Silva et al, (2010), que ponderam que os casos traçadores é uma estratégia usada tanto em estudos quantitativos (exemplos dos marcadores biológicos, marcadores clínicos), como em estudos qualitativos na área de ciências sociais e políticas, na educação e na saúde. Podem ser desenhados prospectivamente ou retrospectivamente. Assim, a análise de situações traçadoras permite examinar em situação os modos como se concretizam os processos de trabalho complexos, que envolvem um considerável grau de autonomia dos profissionais.

Uma importante reflexão em torno de casos traçadores também é que a ideia de traço e de mapa, que é diferente da ideia de decalque. A ideia de mapa, por sua vez dialoga com a perspectiva do rizoma. O mapa e o rizoma traduzem o vir-a-ser.

Diferente é o rizoma, mapa e não decalque. Fazer o mapa, não decalque (...) O mapa é aberto, é conectável em todas as suas dimensões, desmontável, reversível, suscetível em receber modificações constantemente. Ele pode ser rasgado, revertido, adaptar-se a montagens de qualquer natureza, ser preparado por um indivíduo, um grupo, ou formação social (Deleuze e Guattari, 1995). 
Também é importante destacar que um rizoma não inicia nem conclui, mas encontra-se na dobra, no meio, no "inter-ser". Se por um lado, os autores ponderam que a imagem da árvore representa filiação (do instituído), o rizoma é a aliança da pactuação do entre. "A árvore impõe o verbo "ser", mas o rizoma tem como tecido a conjunção ‘e...e...e...". Traz a ideia de transversalidade de um "riacho sem início nem fim.

Após a análise dos casos pretende-se construir os analisadores que marcam a conformação de rede em saúde mental. Nesse sentido, entende-se que os casos traçadores permitem avaliar o processo de trabalho e gestão do cuidado em algumas perspectivas: Construção do cuidado; Dinâmica da equipe: Tipos de tecnologias utilizadas; Relação com o usuário e com cuidador/familiar; Relação entre os diferentes serviços em sua potencialidade na rede e suas fragilidades.

Compreende-se que a estratégia de uso de "casos traçadores", sendo tais casos escolhidos e problematizados pelos profissionais de saúde, permitirá que a perspectiva dos usuários e seus familiares seja também contemplada uma vez que esses são coautores do processo de cuidado em saúde mental. A importância dessas diferentes perspectivas em relação à rede de saúde mental, influenciada pelo movimento de Reforma Psiquiátrica, em diálogo com o Movimento de Reforma Sanitária, é estratégica uma vez que admite-se que essa assistência deve ser configurada de forma compartilhada e que extrapole os muros do instituído asilar psiquiátricos. Ainda mais na atualidade em que a polêmica das internações compulsórias faz reviver no corpo do singular e social o debate em torno da liberdade das diferentes formas de subjetivações.

\section{No meio do caminho havia uma "Rede de Avaliação Compartilhada" fabricando dispositivo "usuário-guia", "redes vivas", "pesquisa interferência"}

Depois da qualificação a pesquisadora que ora escreve essa tese acabou por retornar à sua cidade natal, Recife. Lá os amores, família, o trabalho e o desafio de pesquisar e escrever uma tese sobre Redes em Saúde Mental.

No final de 2013, a orientadora Laura Macruz, integrante da equipe de Pesquisa Rede de Avaliação Compartilhada, coordenada pelo professor Emerson Merhy, pela 
UFRJ, indicou a pesquisadora para atuar enquanto bolsista ligada ao grupo da Universidade Federal da Paraíba. Tal grupo era responsável por desenvolver a pesquisa sobre redes de atenção à saúde na Paraíba e em Pernamubo. Em Pernambuco, Recife teria duas redes temáticas: rede de atenção à saúde mental e sua relação com a atenção básica e rede de atenção em urgência e emergência (RUE). Era uma oportunidade única e potente pela participação em uma pesquisa nacional sobre redes, sendo uma das redes - saúde mental - objeto de estudo da tese ora apresentada.

Em 2014, foram realizadas diferentes leituras sobre conceitos centrais para a pesquisa de avaliação de rede. Foram realizadas leitura sobre elementos que ajudassem a compreender a perspectiva epistemológica desse novo fazer pesquisa considerando a dimensão micropolítica do processo do cuidado em saúde. Foi iniciado um contato também com a Secretaria de Saúde de Recife para contextualizar a pesquisa e entender os processos de permissão para realização de pesquisa científica nos serviços de saúde do município. Contudo, em virtude de um momento histórico contubardo, a morte do então Governador Licenciado de Pernambuco, e então candidato a Presidência da República do Brasil, sofrei acidente de avião onde veio a falecer. Se houve um movimento político conturbado no Brasil com tal acontecimento, no estado a comoção foi impactante.

No início de 2015 as conversas foram retomadas e o diálogo com a secretaria Executiva de Gestão do Trabaho e Educação e Saúde da Secretaria de Saúde de Recife (SEGTES/SESAU) foi produtivo. Uma contrapartida da esquisa também era o diálogo com os Programas de Residência em Saúde desenvolvidos pela Secretaria de Saúde de Recife. Excelente oportunidade uma vez que a pesquisadora, na época estava como Cooordenadora do Programa de residência Multiprofissional de Saúde Coletiva da Escola de Governo em Saúde Pública de Pernambuco (ESPPE/SES-PE), desenvolvido em parceria com a Universidade de Pernambuco (UPE).

Houve diferentes espaços em que se apresentou a pesquisa a diversos programas, principalmente no que se referia à perspectiva da Micropolítica do Trabalho em Saúde, os conceitos de Redes Vivas e principalmente no que se pontuava sobre o Método - O Método é o Encontro. 
Do ponto de vista da Coordenação de Saúde Mental do Município, a pesquisa foi apresentada e pactuada. Após aprovação também junto a SEGTES/SESAU-Recife, a coordenadora indicou dois Distritos Sanitários que tinha uma rede em saúde mental com diferentes dispositivos. Em seguida, a pesquisadora apresentou a pesquisa para a referencia para a saúde mental nesses Distritos Sanitários, que, por sua vez, pactuou um momento com os as gestoras dos CAPS (gestora clínica e geral) que poderiam participar da pesquisa. Depois, a pesquisadora apresentou a pesquisa para as gerências, também se apresentou a pesquisa nas reuniões de equipe, que acontecem semanalmente, uma vez por semana, para os trabalhadores. Em seguida, foram marcados momentos (dois no máximo) para a escolha de potenciais usuários-guia que a equipe identificave como desafiador da Rede em Saúde Mental, por exigir que diferentes serviços e dispositivos de rede se articulem para proporcionar a assistência e o cuidado em saúde.

Em um distrito, conversou-se com um CAPSIII e um CAPS ad; em outro Distrito se conversou com um CAPS III, indicados pela coordenadora de Atenção em Saúde Mental. Mas com o decorrer da pesquisa, um dos CAPS acabou não prosseguindo com a pesquisa, uma vez que não havia pesquisadores locais que fizessem a interface entre a Pesquisa RAC e a atuação, seja enquanto trabalhador ou profissional residente, no serviço. Esse detalhe é um dos diferenciais na aposta de estudo de rede em Recife, enquanto estratégia RAC.

No decorrer do segundo semestre de 2015 varias reuniões ocorreram com diferentes programas de residência, não apenas ligadas à Secretaria de Saúde ed Recife, mas também se convidou Programa da Escola de Governo em Saúde Pública da Secretaria Estadual de Saúde (Residência em Psiquiatria, Residência Multiprofissional e Profissional em Saúde), Programa de Saúde Coletiva do Centro de Pesquisa Aggeu Magalhães (CPqAM/Fiocruz-PE). Também se convidou gestora do Consultório na Rua, ligado à Atenção Básica da SESAU, que colaborou intensamente com a pesquisa. a mesma pactuou que um dos trabalhadores do Consultório Na Rua de Recife participasse enquanto pesquisador local da RAC. Havia a intensão por parte da mesma e do Coordenador da Atenção Basica da Secretaria de Saúde de Recife de produção acadêmica desse serviço inovador da Secretaria de Saúde, por estar ligado à Atenção Básica, mas que também faz interface com a Saúde Mental, afinal o Consultório na Rua é componente da RAPS. Também pondera-se que esse profissional indicado é 
participante ativo da RAC Recife e sua área de referencia se caracteriza por ter diferentes moradores de rua atendidos que também são portadores de transtornos mentais.

De acordo com esse andar da pesquisa e com essas pactuações construídas, a formação de um grupo orgânico da RAC Recife, foi possível ir ao campo. Foram 4 territóios vivos, em que a pesquisadora doutoranda e também bolsista RAC construiu relações e pactuações. A partir dessas andanças foi possível delinear quatro linhas que partir de quatro pontos. Os pontos foram o usuário-guia enquanto aposta em que cada um dos serviços foi convidado a escolher o mais emblemático usuário que desafia a rede de atenção em saúde.

\section{Alguns apontamentos prévios sobre o método dessa pesquisa}

Ponto 1: É estratégico se jogar na viagem rumo ao encontro com as pessoas que forjam redes de saúde mental no cotidiano. Suspender não é abandonar os referenciais, mas se deixar afetar pelo encontro com as pessoas que forjam essa tal rede.

Ponto 2: Teseu no Labirinto rumo a Redes Vivas: Na mitologia grega, Ariadne ou Ariadna era a filha dos reis de Creta e, de acordo com a mitologia grega, apaixonou-se por Teseo, herói mandado pelos reis de Creta para vencer o Minotauro que vivia no Labirinto. O tal Labirinto foi construído por Dédalo (um arquiteto e inventor dessa mitologia) de tal forma que nunca os aventureiros sairiam daquele espaço e acabariam devorados pelo Minotauro que vivia lá, que era metade homem, metade touro.

Teseu decidiu enfrenar o monstro, mas foi primeiro ao Oráculo de Delfos para descobrir se ganharia o desafio. O Oráculo falou que ele deveria ser ajudado pelo amor para vencer o Minotauro. Assim, Teseu foi em busca de Ariadne, filha dos reis de Creta. A nobre disse a Teseu que ajudaria se este a levasse a Atenas para que ela se casasse com ele. Teseu reconheceu aí a única chance de vitória e aceitou. Ariadne, então, deulhe uma espada e um novelo de linha, chamado Fio de Ariadne, para que ele pudesse segurar uma das pontas e assim acharia o caminho de volta.

Teseu então foi para o Labirinto, conseguiu matar o Minotauro com sua espada e graças ao fio de Ariadne escapou do Labirinto. Saiu vitorioso e voltou para sua terra com Ariadne, embora o amor dele para com ela não fosse o mesmo que o dela por ele. 
Por mais aberta que seja a proposta de se lançar numa cartografia, sempre é bom ter um fio da meada para se voltar ao início do que inspira e dar fôlego nesse trajeto. $\mathrm{O}$ ato de escrever no Diário de Campo vai potencializar essa tarefa.

Mesmo em um movimento rumo ao objeto estudado, redes em saúde mental, para compor uma tese acadêmica, admite-se que ao se caminhar a partir da cartografia é apostar na abertura ao acontecimento. Também é se deixar atravessar pelas afecções e tentar que o corpo seja território de acontecimento e nesse estudo o que se buscou incessantemente foi as redes a partir de muitos pontos de vistas.

Não existe um Oráculo com respostas mas se apostou no território de encontros para construir diferentes entrecruzar de olhares e perspectivas sobre um determinado ponto-objeto. Apostou-se num movimento em que a pesquisadora diante de seu campo, no território de encontros e afetos, tentou se afetar em um movimento que parte da impressão, pressão, imprecisão, atravessamento de olhares. Imprecisão como um movimento de afrouxar do fio condutor para a composição e o atravessamento de múltiplos olhares para os diferentes vetores de forças que atravessam as redes de saúde.

$\mathrm{Na}$ cartografia transformamos a realidade para conhecê-la e não o inverso, ou seja é no território do cuidado que se gera conhecimento do interesse (inter-esse) ${ }^{5}$. O movimento para dissolução do ponto de vista do observador desnaturalizaa realidade do objeto, permitindo ao pesquisador abrir-se para os diversos pontos de vista que habiam uma mesma experiência de realidade, mas sem se deixar afetar por aqueles que parecem ser verdadeiros em detrimento de outros que parecem falsos.

O inter-esse é um território de produção de conhecimento por composição de entre-olhares. Mas diferentemente de Passos e Eirado (2010), Merhy (????) sai da perspectiva da intervenção da cartografia e aposta a interferência que ela provoca no objeto estudado. Assim, diversos olhares voltados para um determinado objeto provocam atravessamentos, transversalidade, que desloca objeto e os diversos pontos de vista dos que observam esse objeto.

\footnotetext{
${ }^{5}$ Passos, Eirado (2010). Cartografia como dissolução do ponto de vista do observador. In: Passos et all. Pistas do método da cartografia. Pesquisa-intervenção e produção de subjetividade. Porto Alegre: Sulina, 2010. 109-130.
} 


\section{enQuadrilátero: A EDUCAÇÃo PERMANENTE EM SAÚde COMO ESTRATÉGIA DE ENCONTROS QUE TECEM REDES VIVAS}

Experimentar o estudo das redes em saúde na perspectiva de diferentes olhares gestor, trabalhador, usuário - é um desafio pertinente, complexo e estratégico uma vez que redes vivas em saúde são forjadas por diferentes pessoas que constroem as redes no seu cotidiano (MERHY et al., 2014).

Nesses escritos pretende-se abordar o modo como foi fabricada a pesquisa Rede de Avaliação Compartilhada - RAC em Recife-PE. É uma cartografia do modo como se forjou a pesquisa, os encontros e desencontros rumo ao ponto-objeto redes vivas. Trabalharemos isso em quatro planos. Primeiro falaremos da pesquisadora apoiadora diretamente responsável pelo desenvolvimento da pesquisa nesta cidade, trajetórias e implicações com as redes vivas no território de encontros e desencontros. Depois, dos diferentes pesquisadores locais, suas inserções no SUS e implicações na trajetória das redes em Recife-PE. No terceiro movimento, trabalhamos misturando os pontos no plano do encontro: as RAC Saúde Mental-Atenção Básica e RAC Rede Urgência e Emergência no encontro rumo ao usuário-guia; misturando as RACs. Quarto movimento: o Enquadrilátero, a RAC Aranha da Educação Permanente tecendo redes vivas

\section{Primeiro ponto: a pesquisadora RAC Brincante em Cartografia de Rede em Saúde}

Embora a elaboração do texto seja de vários autores, vamos trabalhar este ponto com foco na pessoa diretamente responsável pelo trabalho de campo em Recife-PE, já que o modo como se teceu a rede de pesquisa tem relação com sua trajetória. E, em certo modo, na primeira pessoa.

As implicações dessa pesquisadora apoiadora com a construção do campo da RAC Recife foram processadas tendo como interferência, pelo menos: a) os debates nos espaços de Educação Permanente da RAC Ariano Suassuna, que integra os pesquisadores que atuam nos estados da Paraíba e Pernambuco; b) os debates entre os 
participantes da própria RAC Recife; c) discussões entre os autores desse capítulo. Ou seja, as reflexões construídas a partir desse primeiro ponto não são uma construção de "em si mesmo", mas sobretudo foram marcadas intensivamente por pessoas dos vários territórios da RAC.

Um documentário foi fundamental para a compreensão de meu lugar de pesquisadora RAC: Tarja Branca (2013), que traz diferentes pessoas falando de sua experiência sobre o brincar. Eu que sempre gostei do sorriso, das brincadeiras de bonecas e jogos. $\mathrm{Na}$ brincadeira, as pessoas podem ser qualquer "coisa", podem ser professora, médica, mãe, flor, árvore, carro de corrida, pássaro, avião.

Há também uma parte do filme muito bonita em que as pessoas são convidadas a ver um pouco de seu eu-criança, momento em que todos se desarmam. Foi esse desarmar que abriu um território da multiplicidade do encontro de tantos olhares de um olho vibrátil (ROLNIK, 2006). A alegria transbordou das pessoas diante daquelas imagens. Esse olhar de criança está dentro do corpo de cada um. Deixar esse olharcriança-brincante potencializar a vida foi o convite.

O nome do documentário traz uma relação com o território do cuidar. "Tarja branca" contrapõe-se aos remédios "tarja preta", prescritos por médicos para pessoas em situações de sofrimento psíquico intenso. Por outro lado, Tarja branca é o contraponto em que todos podem ser qualquer coisa que a imaginação permitir, apontando para a potência de vida em sua plasticidade.

O filme me fez atualizar meu eu-criança, que ama o brincar. Essa parte de mim, que sorri e me faz refletir sobre como é bom ter compromisso com o brincar, com o jogo, com a descoberta. Assim, produzi fôlego e inspiração para provocar este texto e contar essa história de experimentações enquanto pesquisadora, apesar das dores de um estudo em que o corpo de quem pesquisa é o território para explorar potencias de vida e morte que há nos encontros e nos cuidados em saúde (GOMES; MERHY, 2014; ROLNIK, 2006).

Diante desse filme, transbordou em mim a lágrima. Nasceu a leveza da escrita brincante comprometida com a vida. Dessa sensação brotou a leveza de um corpo que se deixa afetar pelas emoções. De não temer o desconhecer, pelo contrário, reconhecer 
que o que importa é se lançar. Tarja branca foi o remédio para despertar minha imaginação para o desconhecido das redes em saúde, mas que tem como baliza o comprometimento ético com o estudo das redes a partir do encontro. Tarja branca é a página em branco para ser escrita em diferentes mãos e perspectivas.

No final do filme toca uma música: "A minha vida é andar pelo mundo". O enquadre da câmera vai abrindo, captando fotos dos participantes do filme que são crianças, imagens enquadradas em diferentes molduras. Destaque para a "Moldura" do quadro cuja imagem remete a um devir-criança potência de vida em plasticidade.

Sendo meu corpo território de afecções a serviço do estudo das redes, torna-se estratégico falar um pouco sobre minhas andanças que forjam meu olhar. Sou de RecifePE, cidade do Movimento Mangue Beat, da década de 1990, que fala que a cidade é da lama ao caos, das pontes entre diferentes territórios de desigualdade. Sou de um território cujo chão é de lama e também berçário para seres vivos que vivem na lama como caranguejo, que anda de lado e se joga na lama para se proteger das ameaças. Da formação em psicologia, passando pelo mestrado na Unicamp (AMORIM, 2008), até chegar no doutorado atual na FSP-USP, andei por muitos caminhos (pernambucano sempre diz "Pernambuco falando para o mundo"): trabalho na rede, trabalho na gestão em diferentes lugares do Brasil, trabalho no Projeto VER SUS Brasil. Em 2013, voltei para Recife para trabalhar como apoiadora em Saúde Coletiva da Secretaria de Saúde de Pernambuco (SES/PE), atuando na estruturação de Programas de Residência em Saúde. Compondo doutorado e trabalho, passei a compor a equipe de pesquisadores da RAC PB-PE, batizada RAC Ariano Suassuna, ícone compartilhado destes estados irmãos. Também na RAC Ariano reencontrei velhos e eternos amigos e construí novas amizades que foram cruciais para superar a dor da solidão de quem pesquisa.

A RAC foi fundamental para que meu corpo de pesquisadora-brincante atualizasse o meu devir nômade (DELEUZE; GUATTARI, 1995) e implicado com as redes vivas. A RAC foi como uma aranha que proporcionou espaços de contato e territórios de abraços, apertos de mãos, conversas em bares, taxis, metrôs. A RAC promoveu o encontro para um estudo implicado com a dimensão ético-estética das redes vivas em saúde para o SUS e abriu espaço para que eu pudesse fabricar e experimentar a pesquisadora-brincante, buscando superar as durezas de uma parte da academia, tendo como estratégia o deslizar por entre possíveis teias do encontro enquanto método. Ao 
mesmo tempo, apostar no encontro enquanto método é atuar no que não é estruturado, o que pode ser aterrorizador para muita gente, por isso o meu devir brincante foi tão importante para superar essas desestruturas.

Por estar no campo do trabalho na Escola de Governo em Saúde Pública de Pernambuco (ESPPE-SES/PE), mais especificamente dialogando e construindo projetos para qualificação das Residências em Saúde da SES-PE, foi estratégico traçar o diálogo da entrada da RAC a partir dos Programas de Residência. Essa vivência trazia a potência da formação em serviços, uma formação teórico-prática potente em provocar os diferentes sujeitos sobre o processo de gestão do cuidado em saúde.

A aposta para a entrada da RAC Recife foi, então, a partir desse lugar da pesquisadora, com forte implicação com a Educação Permanente em Saúde em seus quatro planos do quadrilátero da formação em saúde: ensino, gestão, atenção e controle social (CECCIM; FEUERWERKER, 2004).

Diante das sinuosidades percorridas para viabilizar a pesquisa nesta cidade, aspecto muitas vezes esquecido ou considerado como elemento inadequado para constar nos textos acadêmicos derivados de processos investigativos, serão apresentados alguns pontos marcantes da pactuação do trabalho de campo. Tal contextualização explicita algumas das opções realizadas no cenário singular em que se operou esta pesquisa, que envolvem a construção simultânea do campo e dos próprios atores que a desenvolverão. Entre elas, tendo destaque a delimitação de um grupo de pesquisadores locais que tem como figuras centrais os profissionais cursando residência médica e multiprofissional. Ou seja, apostou-se na construção do campo em serviços em que atuassem profissionais residentes da área da saúde, em razão de sua condição híbrida de profissionais em formação no processo de trabalho. Geralmente, os serviços e profissionais de saúde que convivem com programas de residência sustentam o interrogar-se pelo e para o trabalho no cotidiano do cuidado em saúde.

O primeiro momento de entrada no campo da pesquisa RAC em Recife foi estabelecido entre o coordenador locorregional da RAC Ariano Suassuna e gestores da Secretaria de Saúde de Recife, uma assessora da Atenção em Saúde e coordenadora da Saúde Mental do município, no primeiro semestre de 2014. Nesse momento, foram explicados os trâmites de pesquisa junto a Secretaria Executiva de Gestão do Trabalho e 
Educação em Saúde de Recife (SEGTES-SESAU/Recife). Contudo, o cenário político daquele momento foi bastante conturbado em função das eleições nacional e estadual, principalmente após a morte do então candidato à Presidência da República, Eduardo Campos, ex-governador do Estado. A pesquisadora, na época trabalhadora do serviço público estadual e moradora de Recife-PE, vivenciou essas afetações do cenário.

No primeiro semestre de 2015, o diálogo foi retomado com a SEGTES/Recife. Ao mesmo tempo, também se promoveu uma apresentação da RAC para Coordenadores de Programas de Residência em Saúde de Recife, uma vez que profissionais residentes são lotados em diferentes serviços das redes de saúde. Investir na parceria com profissionais residentes se mostrou potente: incluíamos profissionais geralmente inquietos, já inseridos nos serviços e em conexão com a pesquisadora apoiadora. $\mathrm{O}$ arranjo envolveu uma oferta: a equipe de pesquisadores RAC Ariano poderia participar ministrando aulas de módulos teóricos para Programas de Residência, além de orientar Trabalho de Conclusão de Curso de Residentes participantes do grupo RAC Recife. Trabalhadores residentes viravam pesquisadores; pesquisadores viravam trabalhadores da formação.

Várias reuniões objetivaram envolver na pesquisa Coordenadores de Programas de Residência em Saúde de Recife, Programa de Residência em Saúde Coletiva do CPqAM/Fiocruz e o Programa de Residência em Saúde Coletiva da Escola de Governo em Saúde Pública da SES-PE. Muito trabalho para explicar o que era a RAC, seus referencias e apostas teórico-metodológicas. Era estratégico trazer um grande número de pessoas para essa contextualização e convidar os que desejassem ser pesquisadores locais da RAC. Nesses encontros, se falava de conceitos como micropolítica do cuidado em saúde; gestão do cuidado em saúde; pesquisa de avaliação em saúde tendo o encontro como método (FEUERWERRKER, 2014; FRANCO; MERHY, 2013; MERHY, 2002).

Paralelo a esses encontros, também se procedeu aos trâmites das documentações com gestores de Saúde Mental e SAMU de Recife para viabilizar o desenvolvimento das duas frentes de pesquisa previstas para Recife: a interface entre a Saúde Mental e a Atenção Básica; a produção do cuidado na Rede de Urgência e Emergência. 
Na pactuação do trabalho de campo formal, o diálogo ocorreu com retomada das conversas com as coordenações de saúde mental e do SAMU. No caso da pesquisa sobre interface entre Saúde Mental com a Atenção Básica, a coordenação indicou dois distritos sanitários característicos pela diversidade de equipamentos em saúde da Rede de Atenção Psicossocial de Recife (RAPS). Após a conversa com profissionais de referência para a RAPS dos distritos, conversa com as gerencias dos CAPS. Em seguida, era marcado um dia na reunião de equipe para que todos fizessem o debate em torno de um usuário potencial para ser usuário-guia da pesquisa.

No decorrer do processo, houve uma reorganização de entrada no campo de pesquisa, a partir da interlocução da pesquisadora apoiadora com pesquisadores locais vinculados de alguma maneira com os serviços, enquanto profissionais residentes, trabalhadores ou gestores em saúde. Assim, em um dos CAPS indicados pela Coordenação de Saúde Mental, não foi possível prosseguir com acompanhamento de usuário-guia, uma vez que os residentes pesquisadores locais não estavam mais participando desse espaço como campo de prática. Da mesma forma, outro distrito acabou sendo incluído em virtude de ser espaço de prática de uma das residentes pesquisadoras locais e por também ser um serviço que a própria pesquisadora já conhecia de outras formações e atuações em saúde.

Outra importante entrada no grupo da RAC Recife foi da coordenadora do Consultório NA Rua de Recife, psicóloga que havia cursado graduação com a pesquisadora apoiadora. Essa coordenadora convidou um dos trabalhadores para participar das reuniões de Educação Permanente da RAC Recife. Pelo caminho da RAC no Consultório na Rua, se chegou a um usuário-guia: morador de rua com transtorno mental atendido pelo Consultório NA Rua.

A partir do CAPS indicado pela profissional residente pesquisadora local, que também era um serviço conhecido pela pesquisadora apoiadora em suas vivencias anteriores, foi possível se chegar a uma usuária-guia que recebia cuidados tanto de profissionais do CAPS como da Estratégia de Saúde da Família.

Ao apresentar todo esse trabalhoso caminho, vale sinalizar o quanto ele foi importante para uma pesquisa que se propõe a ter o método traçado pelo encontro. Em primeiro lugar, por ter deixado claro que, ao mesmo tempo em que se fez necessária a 
articulação formal e a tramitação de autorizações seguindo as normas previstas, foi na constituição de outros pactos que a pesquisa foi, efetivamente, viabilizada. Parte importante do apoio que se teve foi baseada nas relações prévias entre os proponentes da pesquisa e alguns dos interlocutores formais. Mas especialmente, a relação com os trabalhadores que se tornaram pesquisadores foi um processo de abertura para inclusão de novos atores. Por fim, os sucessivos recuos e avanços na tramitação formal da pesquisa, que em certos momentos indicavam fragilidade institucional na execução do estudo, por outro lado, permitiram que outras estratégias potentes se tornassem mais evidentes, sendo a inserção fundamental dos residentes como pesquisadores o traço mais marcante dessa construção do campo da RAC. Assim, não só a pesquisa se enriqueceu com tais participantes, como também a formação dos residentes agregou, com ênfase diferenciada, vários elementos conceituais e relacionados à produção de conhecimento que a RAC mobiliza.

Além disso, todas as etapas foram processadas no grupo de pesquisadores locais e com pesquisadores da RAC Ariano Suassuna que atuavam em outras frentes de pesquisa, nas cidades de João Pessoa/PB, Caruaru/PE e em Petrolina/PE-Juazeiro-BA. Pode-se ressaltar ser esse um arranjo de gestão de pesquisa muito trabalhoso, mas sendo o encontro o método, este foi tomado como guia diante de limitações e potências de uma pesquisa de redes vivas.

\section{Misturando os pontos no plano do encontro: misturando as RAC Recife}

No cenário da RAC Recife, desde o início se partiu do território da Educação Permanente, uma vez que esse era o lugar em que se encontrava esta pesquisadora apoiadora. O diálogo com Coordenadores de Programas de Residência e Profissionais Residentes foi uma aposta. E, em cada reunião de EP, se buscava produzir compreensão de que a RAC também deveria ser vista como uma oportunidade para se desencadearem interferências na construção do cuidado (MOEBUS, 2015).

Na RAC Recife, a relação da pesquisa com pesquisadores que eram também trabalhadores nos serviços de saúde se daria partir da Educação Permanente no diálogo entre gestores, profissionais residentes e trabalhadores da rede interessados em refletir e escrever sobre o modo como processavam o cuidado. Mesmo que muitas pessoas estranhassem conceitos da RAC como cartografia, micropolítica, usuário-guia, o 
encontro como método, pesquisa interferência, esses eram problematizados como conceitos-ferramenta para afetar as diferentes pessoas que passaram pela pesquisa e vivenciam o cotidiano das redes de saúde. Mesmo que se sentisse e se considerasse que nem todos os participantes das rodas de conversa sobre a RAC escolheriam compor a equipe de pesquisadores, esperava-se que outros ficassem e compatilhassem a aposta nessa nova forma de estudar redes em saúde.

Nesses momentos de convite para composição de grupo de pesquisa, tentava-se aproveitar o estranhamento diante da proposta da RAC e dos seus referencias práxicos para se instituir um território de diálogo e de disputa ético-estética para a problematização de algumas concepções e apostas (sobre cuidado, sobre pesquisa, sobre avaliação...) e de construção de redes vivas. Com essa postura de convite aberto, investia-se na aposta de que qualquer espaço da RAC era um território de encontro, mesmo que se necessitasse sempre falar de novo...de novo...de novo sobre o que era a RAC e os seus conceitos-ferramentas.

Dos vários encontros com o grupo de pesquisadores locais da RAC Recife, escolheu-se destacar nesse escrito um momento dessas oficinas-convite, que contou com a presença de vários pesquisadores apoiadores da RAC Ariano Suassuna, profissionais do SUS-Recife e residentes em saúde. Foi construído e ofertado ao grupo um texto-provocação, que articulava uma breve contextualização dos momentos anteriores da RAC e a apresentação de alguns conceitos-ferramenta a partir da perspectiva de Abecedário. Inspirando-se antropofagicamente na entrevista Abecedário, de Gilles Deleuze, conduzida por Claire Parnet, construiu-se um texto "Abecedário e Caixa de Ferramentas RAC Recife".

Nesse material havia como conceitos iniciais para marcar o encontro a Carta de Formação de Compromisso e Construção de Agenda. O Primeiro corresponde à estratégia de formação de acordos entre diferentes atores envolvidos em um projeto, e o segundo se refere à importância do estudo das redes em saúde para o cenário político da atualidade, em que é estratégico agregar diferentes olhares para a produção de redes.

Depois se destacou um trecho da entrevista em que Deleuze aborda alguns conceitos de sua perspectiva filosófica e espera que a referida obra seja publicada apenas após sua morte. A partir dessa provocação anedótica de Deleuze (o riso, talvez 
seja um chiste provocador da vida nessa minha estratégia de pesquisadora), destacaramse alguns trechos do texto IN-MUNDO (ABRAHÃO et al, 2014). E dessa buscagarimpo destacaram-se, em ordem alfabética: afecção, agentes institucionais, analisador, efeitos da pesquisa, fontes de conexão do usuário-guia, implicação, intercessores, kit pesquisador, pesquisa em ato, pesquisa interferência, pesquisador local, ponto de vista objetivo, transversalidade, usuário-guia.

A leitura se iniciou então pela letra "a", e após a leitura de cada conceito surgia um debate. Até que um dos participantes fez a provocação: "Por que não começamos a ler do final? Poderíamos refazer a leitura pelo conceito usuário-guia, que acho que é o mais provocador da pesquisa e o elemento mais potente. O que acham?”. Ttodos se olhavam, iam e voltavam com as páginas do texto, e foi-se então construindo um consenso. Era rumo ao usuário-guia que seguiam nossos passos. Qual a definição desse usuário-guia, elemento inovador para o qual se voltam os investimentos dos múltiplos olhares da RAC? O movimento de encontro ao usuário-guia era uma aposta no transitar de rizoma das redes vivas e tal conceito-ferramenta traz a potência de provocar as pessoas para pensar e agir em redes vivas (MERHY et al, 2014; DELEUZE, GUATTARI, 1995).

Mudamos, então, o andamento da leitura de conceitos. Depois do debate sobre usuário-guia se falou em pesquisa interferência, uma vez que as intercessões, desvios do campo, no processo de trabalho da equipe cuidadora acabam "vazando" a intencionalidade do estudo, apontando para o olho vibrátil:" outros caminhos são possíveis...". Na RAC não se está buscando uma pesquisa intervenção porque não se parte de um pesquisador detentor de um saber-fazer capaz de interferir em determinado objeto de estudo, mas todos se afetam nesse encontro do campo da pesquisa (MOEBUS, 2015).

O usuário-guia é provocador da transversalidade do cuidado, uma vez que, para cuidar de uma vida enquanto acontecimento, provocam-se, ao mesmo tempo, elementos verticais (instituídos) e horizontais (instituintes) de modo que esses planos sejam deslocados e afetados transversalmente. Daí a transversalidade é um conceito articulado ao de rizoma do e... e...e... (dentro das reticências transborda vida, incomensurável mas sentida em acontecimento e afecção) (DELEUZE, GUATTARI, 1995). 
De transversalidade passou-se ao conceito de intercessores que se constituem como interferências, artifícios que provocam a diferenciação de saberes, acontecimentos, que deslocam os diferentes planos das relações de saber-poder. Os intercessores desterritorializam, abrindo espaço para novos territórios de modos de existência. Não é o que converge, mas o que diverge, produz desvios e vai abrindo outras potencialidades de vida (mais uma vez rizoma...) (DELEUZE, GUATTARI, 1995).

No processo da RAC há que se considerar a implicação do pesquisador (MERHY, 2004). Ele é corpo que se afeta e afeta esse território dos encontros. Cada um traz suas afecções, pertenças, referências, motivações.

As fontes de conexão do usuário-guia são justamente a busca por todos os pontos de vistas sobre o usuário e as vistas do usuário sobre si em rede viva (MERHY, 2004).

E voltando ao começo, após ter se redimensionado a leitura, retomamos os conceitos de analisador, que é aquilo revelador de acontecimentos, no sentido de provocar ruptura, agregar fluxos, em potencia de reflexões e interferências (LOURAU, 2004).

Afecção é o estado de um corpo sofrendo a ação de outro corpo, configurando uma mistura de corpos a partir dos encontros, modificando-os, aumentando ou diminuindo sua potencia de agir no mundo (DELEUZE, 2002). Esse conceitoferramenta é inspirador.

Esses conceitos vivenciados em interferência foram potentes porque apropriados por meio de um momento de Educação Permanente, no encontro. Naquele instante, os conceitos foram alvo de estranhamento e, nesse estranhamento, foram se construindo diálogos possíveis, explorando, na medida do necessário, as várias apostas dos pesquisadores.

Também, em vários momentos, se buscou misturar as RAC Saúde MentalAtenção Básica e RAC RUE. Entre os efeitos da RAC, foi potente a aposta de construir o campo de estudo contando com a parceria dos pesquisadores locais, até porque seria 
impossível (ou menos rico) fazer de outro modo um trabalho dessa grandeza no que se refere ao objeto - redes de atenção em saúde.

Essa vivência da RAC acabou por despertar no corpo da pesquisadora apoiadora a necessidade de vivenciar seu eu-brincante-pesquisador, atravessada por essas mobilizações das oficinas de brincar com os conceitos. Situar os conceitos é de extrema importância quando se pretende que os mesmos sejam conceitos-ferramenta para transitar nas redes, ter o dinamismo para seguir os territórios dos usuários, e até mesmo tentar construir outros territórios. Assim, com a lida e a vida na RAC, inventou-se um neologismo: enquadrilátero.

\section{Enquadrilátero: a RAC Aranha da Educação Permanente tecendo redes vivas}

A RAC Recife, então, começou com um ponto (a pesquisadora-brincante), abrindo trincheira rumo ao objeto redes vivas em saúde. Com apoio de pesquisadores apoiadores da RAC Ariano Suassuna foi aberto espaço de Educação Permanente convidando Programas de Residência e profissionais que desejavam produzir conhecimento sobre as redes em seus espaços de trabalho. Em diversos momentos, se percebeu a potência desse ir e vir da pesquisa do encontro enquanto método. Assim, os pontos-pessoas foram se ligando e formando uma teia. A RAC Recife foi construída enquanto RAC Aranha da Educação Permanente.

Para uma aranha formar sua teia, ela vai desenhando pontos de conexões reunidos numa trama sem métrica preestabelecida. A distância entre os pontos e a área em que ela venha a dispor a teia depende da articulação dos planos que servem de base para essa arquitetura singular. É assim também a vivência da cartografia enquanto território de atravessamentos e afecções em uma pesquisa interferência para se produzir redes vivas. Por meio do traçado da RAC Aranha da Educação Permanente em Saúde, foi possível forjar um território de vivência dos/nos encontros e desencontros da RAC, mas há que se destacar que a produção dessa teia partiu de um enquadre.

No campo da clínica na psicanálise e na psicologia, o termo enquadre do setting terapêutico se refere a elementos que balizam o encontro entre terapeuta e usuário do serviço. Catani (2013) pondera que, na linguagem coloquial, enquadre significa: dispor 
em um quadro, emoldurar, ajustar-se às regras ou regulamentos, numa referência a certo estado de aprisionamento. Já para a Psicanálise e Psicologia, o termo se refere ao estabelecimento de um contrato entre terapeuta e paciente, de modo a favorecer e oferecer limites ao trabalho terapêutico nessa relação.

O termo enquadre pode estar relacionado à estratégia de proferir, expor oralmente, no diálogo entre terapeuta e paciente o acordo entre eles para o tratamento. Assim, por meio do enquadre se potencializam efeitos para o tratamento. Nessa perspectiva clínica, torna-se relevante construir o enquadramento junto ao paciente, pois diante do enquadre é possível perceber eventuais "ruídos" na relação terapêutica e o manejo desses "ruídos" podem produzir efeitos para o tratamento.

Mesmo que haja uma assimetria de lugares do terapeuta e do paciente, essa não se pauta em posicionar um superior ao outro, mas como dois elementos diferentes e que se complementam, tal como duas peças de um quebra-cabeças. Assim, mesmo que se identifique um "suposto saber" do terapeuta em relação ao "paciente", esse só é suposto.

A clínica como arena para a relação entre diferentes, que exercem seus poderes no processo de cuidado, aponta para a importância do enquadre como território para as relações e os efeitos entre as pessoas que compõem esse encontro.

$\mathrm{Na}$ vivência da RAC Recife, de encontros e desencontros para construir conhecimentos por meio do diálogo entre diferentes, trabalhou-se por dentro desse vai e vem rumo à contratualização para a composição da equipe de pesquisadores e também no diálogo com os diferentes participantes do estudo. $\mathrm{Na}$ práxis da pesquisa, os elementos do quadrilátero (gestão-assistência-ensino-controle social) perpassavam o caminhar do coletivo de pesquisadores. Como na clínica, os vários atravessamentos e afetos das pessoas no encontro provocaram interferências que, na medida do possível, na medida do encontro, foram processados, e os acordos foram revisitados para compor os desejos e as responsabilidades. Por último, se, no campo da clínica, há o papel da supervisão como um terceiro que auxilia na compreensão desse processo relacional, no campo da pesquisa, a RAC Aranha Educação Permanente se forjou no encontro entre os pesquisadores, para que na grupalidade pudessem compartilhar as reflexões em torno do vivido na pesquisa. Assim, no processamento entre pesquisadores, buscava-se (re)significar no território das afecções o (des)encontro com o objeto estudado. 
Os afetos foram estratégicos para que várias pessoas entrassem nessa teia da RAC Aranha EP. Nesse "enquadrilátero da Educação Permanente" a grupalidade foi construída a cada encontro no debate sobre conceitos-ferramentas que fossem potentes para qualificar o cuidado. E assim foi construída a RAC Aranha EP, pontos se encontrando ou se afastando, corpos e afecções no território de buscar entender, olho vibrátil buscando as tais redes vivas e mirando em potenciais usuários-guia. E mesmo que a pesquisa tenha uma finalização formal, essa RAC Aranha EP permanecerá no cotidiano das pessoas.

Tantos foram os afetos e interferências vividos pela RAC Recife, que acabou levando a pesquisadora a brincar na leveza do traço desenhado por conceitos-ferramenta em diálogo com as pessoas que compuseram diferentes momentos do processo. Construiu-se o neologismo-conceito enquadriláterio: mistura antropofágica dos quatro planos do quadrilátero (ensino, gestão, atenção e controle social) para desmontar olhares cansados ou cegos, arriscando-se ao traçado ao invés do decalque, à tarja branca ao invés da captura da tarja preta, e ao (des)montar conceitos-ferramentas para uma clínica da vida. 


\section{REDES E RUAS: QUADRAS PARA ENCONTROS EM REDES VIVAS DE/NA GENTE}

Esse capítulo buscará abordar redes em saúde mental partindo de diferentes perspectivas. Assim, a seguir serão apresentados processos de encontro com pessoas que participam do território de cuidado a pessoas que estão em situação de rua. Um caminho de cuidado construído na rua foi trilhado junto com Equipe de Consultório NA Rua, dispositivo ligado à Atenção Básica da Secretaria de Saúde de Recife (SESAU), voltado ao cuidado a pessoas que moram na rua e demandam cuidados de saúde. Por outro lado, com os encontros e processos construídos no campo de pesquisa, também houve aproximação com o Consultório DE Rua, dispositivo ligado à Saúde Mental da SESAU, que atua junto a pessoas em situação de vulnerabilidade pelo uso abusivo de álcool ou drogas ilícitas, serviço que deve funcionar articulado aos Centros de Atenção Psicossociais Especializados em Álcool e outras Drogas.

Importante situar que esses serviços foram compondo o estudo ora apresentado no decorrer do processo de construção do campo para a avaliação da Rede em Saúde Mental e sua relação com a Atenção Básica (Saúde Mental-Atenção Básica). Em um primeiro momento, quando se investiu em promover convites para a composição do grupo de pesquisa da RAC Recife, houve uma aproximação intensa e afetiva da pesquisadora com a gestora e um grupo de trabalhadores do Consultório NA Rua, tanto que a gestora e um dos profissionais participaram ativamente da produção da RAC Recife e através desse encontro, foi possível se construir um processo de produção de encontro e interferência junto a um usuário-guia.

Em outro momento, foi construída aproximação com equipes que atuam no Consultório DE Rua, em um plano a pesquisadora/doutoranda, ao estar no campo em um CAPSad construiu caminho para estar em diálogo com profissionais do Consultório DE Rua e também participo de uma "vivência" dessa forma de cuidar. E também no decorrer da pesquisa RAC Recife, a própria gestora do Consultório NA Rua promoveu debates entre a pesquisadora/doutoranda e (1) gestor idealizador do Consultório DE Rua no município; (2) trabalhadores do Consultório NA Rua que antes trabalharam no Consultório DE Rua; (3) articulou ações da pesquisa junto à gerente de um CAPSad de 
um distrito em que também atua o Consultório NA Rua. A interferência no encontro foi tão provocador que gerou roda de diálogo entre profissionais dos doies serviços para que pudessem conversar sobre o cotidiano de seus trabalhos na rede de saúde mental e gerou uma visita de um trabalhador Consultório NA Rua e uma trabalhadora do Consultório DE Rua, que morava na rua e estava em situação abusiva de crack.

Mas como são muitos movimentos rumo a encontros (com desencontros) para redes vivas, e como o processo é o que importa na experimentação/afecções do cartógrafo, a seguir serão apresentadas algumas perspectivas rumo à reflexões sobre redes em saúde mental nas ruas. Em primeiro, a pesquisadora reencontra suas implicações diante dua rua enquanto morada e enquanto praça para multidões/multiplicidade. Em seguida são construídas provocações sobre os processos de cuidado desses dois consultórios que em sua origens desterritorializam a clínica e também a saúde coletiva "tradicionais". E um terceiro momento serão apresentadas as provocações sobre esses dois dispositivos: o que as pessoas que constroem o Consultório NA Rua e Consultório DE Rua podem falar sobre seus trabalhos em rede de saúde metal? É possível agir em rede de saúde mental?

\section{Primeiro ponto: a pesquisadora rumo às ruas com encanto pelo nômade e com terror da violência contra quem está à margem}

Como o primeiro ponto de contato com o estudo de redes em saúde mental se forja através da pesquisadora, há que se expor a implicação dessa com a temática das pessoas que moram na rua ou estão em situação de rua.

Pode-se dizer que não se programou essa ida às ruas enquanto território de provocação de cuidado em redes de saúde, afinal se estava se apostando nos encontros com pessoas que vivem redes de saúde mental em seu cotidiano, mas sem outros critérios metodológicos que levariam a pesquisadora para as ruas. Porem aconteceu. As ruas e as pessoas que extraem a vida da rua e o cuidado nas ruas foram compondo diferentes pontos de vistas para essa tal rede em saúde mental. E assim, a seguir o meu devir-rua provocado nessas andanças rumo as redes será exposto em primeira pessoa, a pesquisadora passa a vir numa narrativa de primeira pessoa, que foi provocada em seus afetos dos caminhos sem muros, do seguir. 
As ruas sempre foram convidativas para mim. Criança criada em apartamento, quando as férias chegavam vinham com ela as brincadeiras de rua, mesmo com o olhar atento dos cuidadores porque na rua "pode ter o homem do saco", o "bicho papão", então todo cuidado é pouco diante dos desconhecidos das ruas. Na adolescência, as ruas assumem um outro patamar, por nos acharmos invencíveis as ruas são territórios de desbravar e de conquistar novos conhecimentos, novos amores. Mas foi mesmo na juventude que fui me instigando pela rua por ser um território de encontros de diferentes. Nessa fase os carnavais eram o romper com o tempo de dias e noites se misturando, da expectativa que "O Homem da Meia Noite" sempre ia se encontrar com “A Mulher do Dia" nas ladeiras de Olinda. No carnaval tudo é possível que até apareceu "O Menino da Tarde". O Carnaval nas ruas de Recife e Olinda forjou esse desafiar de fronteiras e é justamente nessa loucura "folie" que ia me mostrando que há vida que transborda, nem sempre o que não entendemos é algo que se teme. A rua passou a ser um território de vida na minha juventude, não que foi fácil assumir esse fascínio, sair da casa da mãe para desbravar o desconhecido tem seus medos, mas conhecer o desconhecido é um caminho.

Na Residência em Saúde Coletiva, foram muitos os novos aprendizados sobre "Saúde" e "Coletivo", até entender que existiam pesquisadores que relacionavam Saúde Coletiva e Subjetividade foi importante para me instigar a percorrer essa trajetória de atuação profissional e como pesquisadora. E um dos momentos que destaco, que foi muito marcante, foi quando li uma notícia que muito me abalou, alguns jovens haviam incendiado um índio que estava dormindo nas ruas de Brasília/DF. Por quê? Um índio, alguém que estava dormindo, talvez sonhando, sem defesas, foi incendiado por jovens por simples diversão? Estava mais para perversão...Foi então que escrevi um texto tão emocionado e eu decidi mandar para a redação de um jornal, eu que nem tinha experiência com esse tipo de escrita e muito mesmo com essa intensão, mas o que doía, nem sei o porquê, era mais forte que eu, que meu receio de receber não. Foi então que escrevi "Se essa rua fosse minha...", texto publicado na coluna opinião do Jornal do Commercio de Pernambuco. Transbordei em palavras sentimento que me consumia, tirou meu sono e fez chorar uma dor que também era de alguém que também é rua, que desafia as bordas pela força dos movimentos e das passagens. 
A imagem-Rua é para mim o desafio que tangencia o devir-nômade, que abre para o novo, mas que não ampara apontando que o que é novo é bom ou mau, é do bem ou do mal. A imagem-rua: chegadas-partidas, (des)encontros, carnavalizar, travessia mesmo contida no limites das calçadas, prédios. Mas quem tem medo do nômade? Quem se fascina pelo nômade?

Assim, o primeiro ponto de partida considerou o desafio da construção de políticas públicas para as pessoas em situação de rua. Quem cuida daqueles que moram na rua? Quais os atravessamentos dos vários pontos da rede de saúde para a produção de um cuidado segundo os princípios e diretrizes do SUS? Quais as estratégias de articulação de redes vivas que são construídas no cotidiano de cuidar nas ruas?

\section{Consultório NA Rua e Consultório DE Rua em Recife/PE: pontos e arranjos politico-assistencial}

Em se tratando de população de rua, deve-se destacar o Decreto Presidencial $n^{\circ}$ 7.053, de 23 de dezembro de 2009, que institui a Política Nacional para a População em Situação de Rua e a cria o Comitê Intersetorial de Acompanhamento e Monitoramento responsável por acompanhar a efetivação dessa política nacional.

Atualmente essa política define a Pessoa em Situação de Rua (PSR) como pessoa integrante de grupo populacional heterogêneo e que possui em comum a pobreza extrema; seus vínculos familiares são interrompidos ou fragilizados; caracterizam-se pela inexistência de moradia convencional regular e que utiliza os logradouros públicos e as áreas degradadas como espaço de moradia e sustento, de forma temporária ou permanente, bem como as unidades de acolhimento para pernoite temporário ou como moradia provisória.

Os princípios dessa política são igualdade e equidade, o respeito à dignidade da pessoa humana, o direito à convivência familiar e comunitária, a valorização e respeito à vida e à cidadania, o atendimento humanizado e universalizado, o respeito às condições sociais e diferenças de origem, raça, idade, nacionalidade, gênero, orientação sexual e religiosa, com atenção especial às pessoas com deficiência.

Ao se voltar para as necessidades dessa população que enfrentam situações de extrema vulnerabilidade, dentre os vários desafios para as políticas publicas de uma 
forma geral, destaca-se o desfio de lidar com a complexidade de questões psicossociais geradoras de sofrimentos físicos e emocionais que essa população enfrenta. O cuidado a essa população representa um desafio também à efetivação de políticas de saúde que considere essa complexidade.

No campo da saúde, algumas referências legais contextualizam orientações para a o cuidado em saúde a pessoa em situação de rua.

A Portaria $\mathrm{n}^{\mathrm{o}} 2.488$, de 21 de outubro de 2011, que aprova a Política Nacional de Atenção Básica, estabelecendo a revisão de diretrizes e normas para a organização da Atenção Básica, para a Estratégia Saúde da Família (ESF) e o Programa de Agentes Comunitários de Saúde (PACS). Essa portaria caracteriza a atenção básica como um conjunto de ações de saúde, no âmbito individual e coletivo, que abrange a promoção e a proteção da saúde, a prevenção de agravos, o diagnóstico, o tratamento, a reabilitação, a redução de danos (destaque da autora) e a manutenção da saúde, com o objetivo de desenvolver uma atenção integral que impacte na situação de saúde e autonomia das pessoas e nos determinantes e condicionantes de saúde das coletividades.

A Portaria GM 3.088 de 23 de dezembro de 2011 institui a Rede de Atenção Psicossocial (RAPS), que é responsável pelo cuidado a pessoas com sofrimento ou transtorno mental e com necessidades decorrentes do uso de crack, álcool e outras drogas, no âmbito do Sistema Único de Saúde. Preconiza que o cuidado a pessoa em situação de rua deve se articular à RAPS.

A Portaria $\mathrm{N}^{\mathrm{o}} 122$ /GM/MS, de 25 Janeiro de 2012 define as diretrizes de organização e funcionamento das Equipes de Consultório na Rua, referidas pela sigla eCR, e definem que .as mesmas devem ser equipe itinerante para atenção integral à saúde da população em situação de rua, desenvolvendo ações compartilhadas e integradas às Unidades Básicas de Saúde (UBS) e, quando necessário, também com as equipes dos Centros de Atenção Psicossocial (CAPS), dos serviços de Urgência e Emergência e de outros pontos de atenção, de acordo com a necessidade do usuário. Devem seguir os fundamentos e as diretrizes da Política Nacional de Atenção Básica, atuando frente aos diferentes problemas e necessidades de saúde da população em situação de rua, e, ao mesmo tempo deve se articular a outros dispositivos da RAPS, como é o caso de CAPS, caso seja necessário. 
Importante pontuar que esse estudo identificou dois dispositivos da RAPS em Recife que cuidam da população em situação de rua. Há dois anos foi organizada Equipes de Consultório NA Rua que seguem as diretrizes da RAPS, mas também há Equipes de Consultório DE Rua, dispositivo criado desde 2004, sendo um dos pioneiros no cuidado a pessoa em situação de rua, sobretudo envolvida com uso abusivo de álcool e outras drogas. Assim, enquanto o Consultório DE Rua trata-se de um serviço composto por uma equipe de trabalhadores vinculados aos CAPSad (vinculados à Coordenação de Saúde Mental do Município), e realizam ações junto a pessoas em situação de uso abusivo de álcool, crack ou outras drogas na via pública. O Consultório NA Rua está ligado à Coordenação de Atenção à Saúde Mental e as equipes de Redutores de Danos estão ligadas aos Centros de Atenção Psicossocial de Álcool e outras drogas.

Em Recife/PE a equipe de Consultório NA Rua é do tipo I é composta por profissionais de nível médio e nível superior, com atuação de 30 horas por semana, e desenvolvem ações em período diurno e/ou noturno e em qualquer dia da semana. No total são 04 profissionais de nível médio, chamados de agente social, e 04 profissionais com graduação, assistente social ou psicólogo.

As Atribuições da Equipe do Consultório Na Rua são: 1) Encaminhar e mediar o processo de encaminhamento para Rede de Saúde e intersetorial das pessoas em situação de rua acompanhada pela equipe; bem como Elaborar com os envolvidos os PTS's dos usuários; 2) Agregar conhecimentos básicos sobre Redução de Danos, uso, abuso e dependência de substâncias psicoativa a população em situação de rua e/ou usuários de álcool, crack e outras drogas; 3) Dispensar insumos de proteção à saúde; 4) Acompanhar o cuidado das pessoas em situação de rua de modo articulado com demais pontos de atenção da rede de saúde; 5) Promover estudos de caso, em equipe, semanalmente; 6) Participa no GT de População de Rua distrital e Fórum Metropolitano de População de Rua; 7) Referenciar as pessoas em situação de rua acompanhadas do território para Unidade de Saúde de referência.

Como se expos anteriormente, a relação construída entre a pesquisadora e o Consultório Na Rua foi construída com a participação de coordenadora e profissional de uma das equipes. Por ser um serviço relativamente novo, havia a intensão de produzir estudos sobre as práticas desenvolvidas. Além disso, por coincidência, a gestora do 
consultório também havia estudado com a pesquisadora, ou seja, “já se conheciam de outros carnavais". A coordenadora então construiu uma agenda de conversa em que a pesquisadora apresentou a pesquisa RAC para as duas equipes de Consultório NA Rua, cada uma atende duas regiões com destacado número de pessoas em situação de rua. Estava apostado no convite à produção sobre redes numa perspectiva diferente, considerando contexto micropolítico de redes em saúde numa perspectiva de redes vivas a partir de diferentes perspectivas de quem promove, trabalha e usa as redes de saúde. Dentro desse contexto estava a pesquisa de doutorado, buscando entender redes em saúde mental. De duas equipes, uma foi prontamente acolhedora para participar ativamente do processo de pesquisa, com trabalhadores enquanto pesquisadores locais; a outra equipe pontuou que estaria disponível fazer visita ou entrevistas com profissionais, mas não haveria profissionais no papel de pesquisadores locais.

Durante o segundo semestre de 2015 até primeiro semestres de 2016 houve várias atividades envolvendo pesquisadora e pesquisadores locais da RAC Recife. Em um primeiro momento, a gestora e um dos trabalhadores participavam dos encontros mensais do grupo de pesquisa e também da abertura do campo de pesquisa no serviço. Posteriormente, ocorreu encontroas mais sistemáticos entre pesquisadora e equipe para promover a escolha de um potencial "usuário-guia". Foram três encontros para a escolha do usuário. Cada encontro havia muita intensidade, mesmo tendo que explicar várias e várias vezes sobre conceitos de micropolitica do cuidado em saúde, do encontro entre diferentes pessoas como método da pesquisa, do que seria usuário-guia que é diferente de estudo de caso...era como se valesse a pena construir a interlocução e manter o contato com as pessoas.

Era muito interessante falar das pessoas como potenciais usuários-guia pois gestora e trabalhadores traziam que eles tinham muitas pessoas que são emblemáticos para a rede de saúde. Eles cuidavam de pessoas que os vários serviços não cuidam. Essa equipe em particular acompanha casos por meses e meses pela complexidade do projeto terapêutico a ser construído para a pessoa.

Era também interessante ouvir a equipe ouvir o que elas falaram sobre o processo de cuidado que construíam. Assim, ao promover a leitura da transcrição dos encontros para escolha do usuário, havia uma autoreferência do agir da equipe em relação a atra intervenção que haviam promovido. Para situar como era o trabalho deles 
havia uma referencia a um usuário emblemático: "Conheço Não", era o nome da pessoa. Morado de rua que em qualquer tentativa de diálogo com os trabalhadores levava a essa frase, substantivo próprio ao mesmo tempo em que é abstrato. Foram tantas idas e vindas para cuidar de "Conheço Não" na rua. Um dia ele precisou ser internado em um CAPS e quem foi a ponte foi a equipe do Consultório NA Rua, que mesmo no CAPS continuou fazendo algumas intervenções. Destaco o banho que uma das trabalhadoras acabou dando nesse usuário pois poucos foram os trabalhadores do CAPS prontificados em fazer tal intervenção...talvez uma maternagem também pode estar em um ato em que um banho é um acontecimento para remover certas cascas. E um certo dia de vista da tal trabalhadora no CAPS em que o usuário estava sendo cuidado, "Conheço Não" falou seu nome e disse onde morava. Mesmo diante da surpresa ou desconfiança de alguns, no outro dia pessoas da equipe vieram com o carro do Consultório NA Rua e foram seguindo o caminho até uma outra cidade. E de rua em rua, praça e esquina, não é que chegaram até a casa desse usuário(!). Quem sabe o que é confiar em um usuário "Conheço Não" que guia até um passado de afeto em outra cidade, outro território. Não sei se daria para colocar critérios estatísticos nesse acontecimento.

Mesmo depois da equipe tendo escolhido o usuário-guia (que não foi $\mathrm{o}$ "Conheço Não", que merece um escrito a parte pela potencia do encontro que promoveu), o processo de trabalho deles é tão complexo que muitas vezes para explicar a pessoas o que eles faziam, seja algum cidadão que passava na rua, ou mesmo um profissional de saúde, algumas vezes se referenciava o trabalho deles pela singularidade da população que cuidavam.

Também se falava que a atuação também se construía em rede, mesmo que tensionando a rede a atender essas pessoas marginalizadas, que são os moradores de rua, mas que eles por ser dispositivo novo, estão em processo de construção no fazer diário. A atuação entre serviço é uma das características do Consultório NA Rua, o acolhimento é na rua, mas há necessidade de articulação com outros serviços de saúde, seja unidades básicas, no agendamento de consultas médicas, ou a unidades especializadas. Há uma ação intersetorial marcante com os serviços da Assistência Social não apenas nos fóruns políticos mas no cotidiano, mesmo que numa grande parte das vezes seja no referenciar da assistência social de casos que não se consegue mais atuar enquanto Sistema Único de Assistência Social (SUAS). 
Foi um usuário dentre os vários que a equipe não conseguia atuar, não conseguia utilizar tecnologias de cuidados que eles operavam com tantos usuários emblemáticos desse serviço. A escolha da equipe foi construir um processo de usuário-guia junto a um usuário que ficava parado em uma das esquinas do território de atuação da equipe. Mas esse processo merece um capítulo a parte dada a provocação do encontro em acontecimento.

Mas paralelo ao acompanhamento ao usuário-guia, que não falava muito, e ficava parado em uma esquina, foram muitas oportunidades de acompanhar o trabalho da equipe. A conversa no carro, quando a equipe ainda tinha (desde março até junho de 2016 a equipe estava sem carro disponível para o trabalho e todas as vezes essa pesquisadora foi de ônibus com a equipe para acompanhar o trabalho), ou nos tantos transportes trazia uma aproximação da pesquisadora com o modo como se construía o cuidado a essa população. Trata-se de um serviço instituinte, que busca trazer para a rede de saúde pessoas à margem da sociedade por serem moradores de sua. Atua na trama das tensões do cotidiano buscando construir acordos diretos com profissionais de outros serviços de saúde e da assistência, mesmo que também se ocupe espaços de fóruns de referência para essa população. Mas mesmo com dificuldades e contradições, são pessoas implicadas com o trabalho nas ruas, por suas histórias de vida e pelo desterritorializar que a pessoa em situação de rua provoca em nós.

Em um dos momentos desse processo rumo a rede em saúde mental surgiram também questionamentos sobre o serviço como componente do sistema de saúde, da luta constante para promover cuidado integral. Assim gestora e também profissionais apontaram para a importância também em se entender o trabalho do Consultório DE Rua, até porque quando falavam do modo como eles buscavam promover rede, o único serviço que a equipe fazia paralelo, pela semelhança da atuação instituinte nas ruas, era o Consultório DE Rua. Assim a gestora do Consultório NA Rua promoveu encontro da pesquisadora para entrevista com um dos idealizadores do Consultório DE Rua em Recife; articulou entrevista com trabalhadores do Consultório NA Rua que em outras épocas atuaram no Consultório DE Rua; agenciou diálogos com gestora de CAPSad da região de atuação da referida equipe de Consultório NA Rua, diálogos com profissionais redutores de danos ligados ao CAPSad e trabalhadores e gestora do Consultório NA Rua. 
Em outra via, em outro território (distrito sanitário), esse movimento de encontro com profissionais Consultório DE Rua também foi construído junto ao CAPSas participante do estudo da RAC e do Doutorado dessa pesquisadora. Na oportunidade das ações no CAPS ad, solicitou-se conversa com trabalhadores do Consultório DE Rua referenciado pelo CAPS.

O primeiro contato com o Consultório DE Rua foi uma reunião, promovida pela gestora do Consultório NA Rua, objetivando apresentar a pesquisa a coordenadora geral dessas equipes, que ficam lotadas nos CAPSad mas também conta com referência em nível central, mas especificamente atrelada à coordenação de saúde mental. Esse primeiro contato de apresentação da pesquisa também foi importante para situar como estava organizado esse serviço naquele momento e também como ele foi construído.

Posteriormente um importante momento foi a entrevista com um dos idealizadores eu participaram da implantação do serviço Consultório De Rua em Recife/PE, que ocorreu em 2004, sendo um dos pioneiros no país. A conversa com esse pioneiro na implantação das ações do Consultório DE Rua foi importante pela implicação e afeto que o mesmo constrói quando fala de sua história de vida que também é atravessada pelo desejo em cuidar de pessoas em condições de uso abusivo de álcool ou substância psicoativa. Quando jovem, em um encontro impactante com um "moleque" que ia assalta-lo acabou, por meio de uma conversa em tom de brincadeira, convidando-o a participar de uma ação com arte e educação. Os processos disparados nesse encontro inusitado produziram outras afecções que o fez enveredar pela arte e educação como meio para provocar pessoas em situação de vulnerabilidade.

Da formação e atuação em educação passou a trabalhar na área da saúde sobretudo construindo intervenções junto a pessoas em situação de vulnerabilidade pelo uso abusivo de álcool e outras drogas. E assim, em 2004, foi trabalhar na implantação do "Programa Mais Vida", política da Secretaria Municipal de Saúde de Recife para combater. Nessa época, o "Programa Mais Vida" era ligado diretamente ao gabinete do secretário de saúde e o entrevistados era uma das pessoas gestoras desse programa.

Segundo Mota (2012), as atividades desse programa estavam voltadas para divulgação de informações sobre drogas lícitas e ilícitas, seu consumo, riscos, e consequências, como também, o tratamento e reabilitação de algumas pessoas com uso 
nocivo ou dependentes de drogas. Para tanto, o foco das ações do Programa se direcionavam a estratégias de redução de danos, que refere a um conjunto de estratégias (individuais e coletivas), no âmbito social, sanitário, político e legal, com o objetivo de reduzir os prejuízos causados pelo consumo de drogas e melhorar a qualidade de vida dos usuários, sem a obrigatoriedade da interrupção desta prática. Naquela de sua estruturação, o programa apresentava quatro modalidades de funcionamento: Centros de Atenção Psicossocial (CAPSAD), Albergues Terapêuticos (denominadas Casas do Meio do Caminho - CMC), as Unidades de Desintoxicação e os Consultórios de Rua.

Considerando o cenário nacional, importante anunciar que a primeira experiência de Consultório de Rua (CR) teve início em Salvador, na década de 1990, numa ação de organizar uma metodologia de aproximação junto a crianças usuárias de drogas e em situação de rua, idealizada pelo professor Antônio Nery Filho. Em 2004, o Consultório de Rua foi implantado em um Caps AD de Salvador.Em 2009, enquanto política nacional, o Consultório DE Rua passou a incorporar o Plano Emergencial de Ampliação de Acesso ao Tratamento e Prevenção em Álcool e outras Drogas do Sistema Único de Saúde (Pead). Em 2010, passou a ser um dispositivo de relevância estratégica para compor o Plano Integrado de Enfrentamento ao Crack.

A aposta nesse dispositivo era que, através do Consultório de Rua, seria construído um meio de acessar os usuários que não iriam buscar um serviço especializado para tratamento de abuso de substância psicoativa, seja por demanda espontânea ou encaminhada por algum outro serviço da saúde, assistência social. Assim, importância desse serviço estava na sua inovação ao preencher um "hiato" entre usuários em suas "cenas de uso" e os serviços dos CAPSad (Francisco, Espíndola, 2015). Ao se depararem com cenas de uso de uso de drogas ou álcool se promove aproximação, através do diálogo, de modo gradativo, de modo a promover ações de redução de danos de álcool e outras drogas, para promover vida.

Na época o Programa era ligado ao gabinete da Secretaria Municipal de Saúde. O Consultório de Rua do Recife contava com seis equipes, uma para cada distrito sanitário do município. cada equipe era formada por profissionais concursados 3 e contratados, com perfil específico 
Redução de Danos. E importante destacar que Recife foi o primeiro município a formalizar o cargo de agente redutor de danos como servidor público. Cada equipe era composta por assistentes sociais, psicólogos, agentes redutores de danos, arteeducadores, oficineiros e motoristas. Também se contava com vans adesivadas do programa para levar profissionais para o campo de trabalho: as ruas.

O entrevistado expressou sua implicação com o trabalho no Consultório DE Rua, que foi sendo reorganizado na medida $m$ que havia redirecionamentos em relação a política de enfrentamento sobretudo ao "combate" ao uso abusivo de substâncias psicoativas. Posteriormente houve a mudança para a Atenção à Saúde, depois foi para a Coordenação de Saúde Mental que construiu uma relação de lotação das Equipes de Consultório DE Rua nos CAPSad. Assim em Recife/PE há ainda Consultório DE Rua ligado a CAPSad como uma produção de desenho investido pelo município.

Tal mudança também foi um rearranjo diante da mudança da política do Ministério da Saúde que redefiniu as ações de Consultório DE Rua como sendo ligados à Atenção Básica, como de ponderou no início dos escritos desse capítulo, perspectiva que também foi escutada por outras pessoas que participaram desse estudo. Mas Será que esse dispositivo ainda vai ter governabilidade para transformação do cenário do uso abusivo de álcool e substâncias psicoativas?

Após conversas com grupo de redutores de danos dos CAPSad entre eles e depois promovendo grupo entre eles e profissionais do Consultório NA Rua, foi possível abordar a fragilidade do serviço. Há dificuldade de articular as ações do Consultório DE Rua com o CAPSad. Parece que a estratégia de levar a Rua para dentro do CAPSad acabou sendo capturada pelo movimento de forças instituídas de "encapsulamento", dentro da lógica do CAPS, do que o contrário. A Rua e os usuários de substâncias psicoativas não conseguem transversalisar as ações de cuidado no CAPS.

Sobre essa reflexão, uma cena que presenciei me afetou muito. Estava na sala de espera em um CAPSad no período noturno. Na sala de espera vários usuários aguardavam consulta médica. Eis que um dos técnicos falava de forma incisiva reclamando de um dos usuários do CAPS que estava fumando em uma das áreas do CAPSad. Eu pensei: mas e a estratégia de redução de danos, onde está? E se o usuário estivesse na "fissura" por abstinência de alguma substância psicoativa, não era mais 
plausível substituir por enquanto com o tabaco. Como pode ao mesmo tempo ser um "ambiente livre do fumo", como assim era o CAPSad, se o fumo do tabaco pode ser uma outra possibilidade diante da "fissura" do crack?

Dessas andanças junto a gestores e trabalhadores do Consultório DE Rua, uma vivência me trouxe afecções sobre a potência do trabalho do Consultório DE Rua. Uma noite, após conversa com Redutores de Danos e técnica do CAPSad que compõe o Consultório DE Rua para entender o trabalho deles, fui eu e uma estudante de psicologia estagiária no serviço, fazer uma ação em uma área de vulnerabilidade. Era uma área de mercado publico, mas na noite o local ganhava o contorno da obscuridade do ilícito. Nas calcadas os caminhos era de atenção e espreita. A primeira orientação era para deixar a na van a bolsa e materiais de valor e cada um pegar os "insumos", eu são camisinhas masculinas e gel lubrificante para serem distribuídos no campo. Cada um também ganhou coletes bem visíveis com o nome "Consultório DE Rua" e "SUS".

A primeira parada era para conversar com um senhor alcoolista para saber como esse estava, se pensava em ir ao CAPSad para uma escura mais especializada no acolhimento. Um "colega" dele se afastou quando o grupo do Consultório DE Rua chegou. Depois chegou um rapaz muito jovem, tombando ao dar seus passos, querendo saber o que se tratava e querendo de cara camisinha. Um dos redutores se aproximou, entregou camisinha e gel e falou que era Consultório DE Rua, explicando o que era o serviço e que estavam ligados aos CAPSad. O rapaz perguntou se ele quisesse ir “agora/nesse momento?/eu posso ir?". Daí o profissional explicou que poderia diminuir o uso do álcool ficar um pouco melhor para poder conversar com profissional do CAPS e falou dos horários com acolhimento no serviço. Já logo me inquietei porque era como se a potencia desse encontro que tangenciava o convite ao cuidado se esbarrasse numa "grade de horários para o acolhimento". E se o CAPSas fosse 24horas? Não necessariamente alguém embriagado seria acolhido...

Depois passamos por jovens que queriam lubrificantes e camisinhas e pareciam que já conheciam o pessoal da equipe que reforçavam a importância do uso da camisinha e gel como também da importância em tomarem água.

Na medida que caminhamos o ambiente ia ficando cada vez mais estranho. Menos pessoas andando pelas calcadas. Umas mulheres sentadas e uns homens 
próximos conversando. Quando nos aproximamos um jovem logo se levantou e disse que era de "fazer aquilo". Estava conversando com uma prostituta. Dai muito pausadamente um dos redutores explicou que eram da saúde e que estavam ali para promover saúde. Explicaram ações de redução de danos, distribuíram camisinha e gel. Daí a profissional falou com uma das prostitutas que estava inteiramente na "fissura" pelo uso do crack. Mal conseguia ficar de pé, apesar de estar em uma ação para fechar o programa com o rapaz que "deu um pulo" quando nos aproximamos. Mesmo assim a profissional falou que estava disponível para ele conversar, que existe o CAPS e que de outra vez voltará a falar com ela.

Estávamos juntos mas era como se o grupo de profissionais do Consultório tivessem olhos capazes de olhar movimentos que não eram tão prontamente percebidos por mim ou pela estudante. Uma linguagem da sutileza, observação e gestos. Logo que nos aproximamos dessa área das mulheres de programa, logo ouvimos o cantar de pneus de uma das viaturas da policia militar, que saiu as pressas em uma das ruas próximas ao mercado. Uma outra profissional do sexo, também "chapada" foi muito acolhedora e explicou que havia havido uma acao da segurança 'publica e muitas pessoas dali “viciadas" “debandaram”. Ela não, ela não era viciada, estava ali porque não podia estar em casa, fazia uso de crack, mas se quisesse parar, parava. A jovem era muito bonita, apesar de estar com o desgaste "dessa vida" e falava com lágrimas nos olhos e um cigarro na ponta de uma das mãos. E era muito afetuosa. Abraçava várias pessoas do grupo do Consultório DE Rua e dizia "que bom que vocês vieram porque a gente é esquecido", não eram esquecidos pelo "pessoal do movimento" (venda de drogas) e pela "polícia". Também nesse espaço um homem se aproximou e disse que conhecia um dos redutores de um outro lugar. Ficamos sem entender muita coisa. Depois uma pessoa da equipe disse que estávamos sendo vistos pelo "pessoal do movimento" e ele era um deles. Possivelmente queria se o víssemos também.

Falamos também com uma mulher que havia sido acolhida pelo Consultório DE Rua em outra época, que a encaminhou para um serviço de saúde, um CAPS de outra região. E ela estava ali bem e desenvolvia seu trabalho, era uma profissional do sexo, mas "estava limpa”. Pegou camisinha e lubrificante.

No pós-campo, fizemos uma conversa rápida. Primeiro eles preencheram um questionário, instrumento de registro das acoes da noite. Depois trocamos impressões, 
do carro da policia cantando pneu; do possível senhor simpático ligado "ao movimento"; a estudante colocou que importante era a atuação do Consultório de Rua que se aproxima dessas pessoas promovendo uma assistência importante. Eu falei que foi um dos momentos de encontro d mais afecções que vivi na pesquisa. era uma clínica do encontro, as marcas para o encontro eram os afetos, o coração pulsando, a redução de danos como um território de convite para a vida, seja em que situação for. Era como uma música de Legião Urbana "Só por hoje", só por hoje as pessoas por um momento puderam conversar, puderam ter acesso a outra janela de um encontro rápido só pelo encontro. Sei lá do que passou ou o que terá por vir, por hoje foi o encontro como fator de proteção para eles e para nós pelo simples encontro entre corpos vivos, a rede viva em acontecimento, transbordando nas ruas e as ruas na gente enquanto território do encontro. Viver é mesmo uma “dádiva fatal”, mas só por hoje o por-vir (...).

Será que o dispositivo Consultório DE Rua findará? Ou será transformado? Como ficará a relação do CAPSad com o Consultório DE Rua? Qual o lugar desse dispositivo na RAPS? Qual a relação entre Consultório DE Rua e Consultório NA Rua na RAPS em Recife? Pensando nesses questionamentos foi construído um canal de escuta e diálogo entre esses dois dispositivos que atuam em uma mesma região do município para tentar achar algum usuário que pudesse estar na função de usuário-guia, provocando questionamentos sobre esse entre serviços.

\section{Consultório NA-DE Rua: (des)encontros na/em rede}

Vários movimentos e provocações acabaram levando para que se buscasse uma "mistura" entre os Consultórios. Assim, houve uma concersa entre gestora do Consultório NA Rua e uma gestora de um CAPSad do mesmo territóriop de atuação de Equipe do Consultório NA Rua. Foi então agendado conversa com uma Redutora de Danos que já compunha a equipe do CAPSad há algum tempo e portanto já tinha uma vivência do processo de cuidado do Consultório DE Rua. Depois se promoveu encontro entre profissionais do Consultório DE Rua e Consultório NA Rua para debaterem sobre como constroem rede de cuidado em saúde. Esse debate também poderia rastrear algum usuário que fosse intercessor provocador de redes vivas.

Um primeiro elemento que chamou atenção era que, diferente do CAPS ad da vivência no mercado público, que foi ponderado anteriormente, não havia um 
profissional com formação universitária do CAPS compondo essa equipe de Consultório DE Rua. A equipe participava das reuniões de equipe do CAPSad, tal como ocorria com a outra equipe, entretanto a gerente do CAPS era quem se articulava diretamente aos redutores de danos. Esses apontavam para a dificuldade dessa lacuna pois acreditam que há qualificação do processo quando há uma articulação entre redutores e profissionais com graduação no sentido da qualificação do trabalho. Nem sempre eles podem promover algumas ações por serem técnicos de nível médio. De certa forma, os trabalhadores do Consultório NA Rua também ponderaram que houve uma potencialização do trabalho na composição da equipe com integração entre profissionais de nível médio (educadores sociais) com profissionais universitários.

Além do mais, explicou-se que o Consultório DE Rua atua considerando o território pessoas que estão em situação de rua ao mesmo tempo em que estão na cena de uso do álcool e outras drogas, diferente da equipe do Consultório NA Rua que busca atuar em pessoas em situação de rua, tendo ela qualquer problema de saúde que demande cuidado por parte da equipe.

Diferente da outra Equipe de Consultório DE Rua do mercado público, envolvida com cena de uso de crack daquela área e em outros lugares uso de inalantes por crianças e adolescentes em outa área do mesmo distrito sanitário, essa equipe de redutores atua na atenção a pessoas em alcoolismo e junto a crianças e adolescentes fazendo uso de inalantes, especificamente "cola de sapateiro". Esse dado chamou atenção pois também é algo falado pela outra equipe de Consultório DE Rua, que também foi ponderado pela equipe do Consultório NA Rua. Entretanto muitas das pessoas abordadas pela equipe do Consultório De Rua, nessa cena de uso abusivo de álcool ou outras drogas moram nas casas com seus familiares. Fazem uso do álcool ou droga e voltam e assim "não chamam muito atenção" para uma situação de vulnerabilidade. Nem mesmo a comunidade sofre algum tipo de "interferência" com essas cenas de uso abusivo de álcool ou cola. Nem mesmo alguns profissionais se mobilizam diante de alcoolistas ou drogaditos que estão em suas áreas, pois parecem que esses fazem parte da paisagem local.

Como então enxergar essa linha limítrofe de enxergar a vulnerabilidade de situação de dependência química que expõe a vida de uma pessoa em risco? Alguns redutores expressaram que é estratégico parceria com alguns agentes comunutários que 
se mobilizam para o cuidado a algumas dessas pessoas. Assim acionam a equipe de redutores para que possam acessar algumas dessas pessoas alcoolistas e drogaditas em sua área. Também fazem parceria promovendo espaços de "educação continuada" para falar de uso abusivo de álcool e drogadição. Mas o estratégico é quando forma essas parcerias com os agentes comunitários de saúde para construírem esse acesso ao usuário.

Nesse sentido, destaca-se que a educação permanente em saúde não é apenas promover o debate sobre um assunto importante para a saúde, nesse caso o alcoolismo ou drogadição, mas está sobrtudo na vida, é um movimento que mobiliza as pessoas a buscarem construir conhecimento para um processo de cuidado para "Dona Maria", "Seu João", articulando vários conhecimento, habilidades e atitudes para um ato de cuidar. Esse fazer modelado pelo encontro com uma pessoa mobilizadora é o lastro do trabalho do Consultório NA Rua, sendo que a diferença está "no olho vibrátil” dos trabalhadores que se voltam para a situação de rua, depois é que acessam qual é mesmo o problema daquela pessoa - "O Pezão", "O Conheço Não", substantivo própriosingular, com necessidades específicas que requer "linhas de cuidado" específicas construídas durante o processo do cuidado. Esse dado processual de "linha de cuidado" não estavam tão presentes nas atuações e diálogos nas equipes de redutores que participaram desse estudo. Parece mais que os redutores de danos atuam como o "SAMU" das Ruas, acolhem, escutam, intervêm e encaminham para outro seguimento, enquanto que Consultório NA Rua, pelo menos na equipe que participou do estudo, está mais para equipe de atenção básica na Estratégia de Saúde da Família. Embora haja governabilidade maior para construir Projetos Terapêuticos Singulares para os usuários que estão em situação de Rua, muitas vezes se defrontam com barreiras dos outros serviços da rede.

Diante da diferença entre esses equipamentos de saúde, no que se refere à governabilidade e atravessamentos de dispositivos que "abrem e fecham as portas" de acesso ao SUS, ressalta-se o transporte e o cartão SUS. De um lado, ambos Consultórios relatam a importância do transporte como "as pernas dos serviços", lá é um território de encontro para debater estratégias de ação junto aos usuários e trazem mobilidade para a "agenda" do serviço: para a Rua, "vão as vans" carregando as pessoas, equipe motorista-nível médio-nível universitário (o hífen sinalizando pela articulação entre 
diferentes que se complementam) e até mesmo usuários que necessitam de atendimento em outro serviços. Se falta carro, esse é um dado muito significativo pois parece que há "quebra das pernas" dos Consultórios que atuam na rua.

Por outro lado, nesse percurso de levar usuários para outros pontos da rede de saúde o Consultório NA Rua tem governabilidade de regular, de acionar outros serviços porque são referencia para a população de rua, população nômade adscrita em seu território: "Até cartão SUS eles podem fazer" (frase-síntese que conota poder). Assim, em vários relatos o critério "nômade" foi chave para que usuários desse serviço pudessem acessar outros serviços da rede, mesmo que necessitasse ter ao lado um profissional do Consultório que "endossava" o critério "nômade" como elemento-chave para o acesso ao serviço. Mas não s percebeu o caráter tutelar desse "estar ao lado" e sim um facilitador para uma rede de conversação entre usuário-profissional de saúde. Quantas e quantas vezes relataram que o profissional nem sequer recebia o usuário em situação de rua porque ele estava "fedendo", e estava lá o profissional do Consultório "mediando" essa relação.

Sobre "ferramentas de trabalho" que apontam para o modo de construção do cuidado também está na evolução do atendimento prestado. O Consultório DE Rua tem uma ficha padrão de preenchimento que aborda elementos gerais de uma noite como número de pessoas que estavam na área no momento da ação, insumos distribuídos (camisinha feminina, masculina, gel lubrificante, seringas, etc), profissionais que estavam na ação entre outros. Já o pessoal do Consultório Na Rua possuem "prontuário" dos usuários, acessam serviços de saúde e outros do Serviço Social como Abrigos, ou da Segurança Pública como Instituto Tavares Buril para confeccionar Registro Geral (RG) dos usuários.

Tanto o pessoal do Consultório DE Rua e Consultório NA Rua também propuseram buscarem um caso que estivesse na área deles que pudesse receber o olhar dos dois dispositivos, era uma tentativa de "interferência" para promover rede entre os Consultórios. Foi realizada então uma visita a um jovem que estava em situação de vulnerabilidade. Estava antes dormindo na rua, passou várias vezes nessa situação, foi quando o Consultório NA Rua conheceu o usuário e passou a acompanha-lo, por alguns mesme. Mas em seguida houve o movimento de volta desse usuário para a casa de sua mãe, porém ele não estava se sentindo bem morando lá, e estava intensificando muito o 
uso de crack. Como estava constantemente circulando na área do Consultório NA Rua, foi então proposto uma vista com uma profissional Consultório DE Rua e um profissional do Consultório NA Rua, numa espécie de interconsulta de acolhimento. Foi muito potente essa interferência que a pesquisa promoveu porque em um momento estávamos nós três - eu, a redutora e o agente social - sentados no sofá da sala da casa da mãe do rapaz conversando com ele. Esse que estava trancado no quarto (há uma relação do trancafiamento que ele faz de si com as crises que ele vivencia) falou para nós que "estava virado", passou a noite na rua, fez uso de crack e estava dormindo. Ele que antes acumulava coisas velhas no quarto, de uma hora pra outra, jogou tudo fora. Queria voltar a morar na "casa dele" que ali não era a casa dele. Mas ele foi falando e saiu do chão na porta do quarto. Foi falando, depois foi para a cozinha e preparou ele a sua refeição. Sua mãe também acabou se sentando no sofá e falando de seu sofrimento. Pelo que conversamos o trio - eu, redutora. agente social - foi a primeira vez que ela conversou sobre o filho e sobre sua relação com ele e o sofrimento, nesse enredo que ela trazia a droga era mais um elemento, perverso por acentuar a dor, mas havia muita e muita história para contar da vida do filho e da vida dela, que mudou tanto por causa do filho. No fim da visita, a agende redutora de danos e agente social iriam problematizar em reunião de equipe a visita para ver como iriam prosseguir com a escuta.

O que será que vai acontecer com o Consultório De Rua? Vai ser "engolido" pelas forças instituídas do CAPSad, que abriga ao mesmo tempo "ambiente livre do fumo" e "estratégia de redução de danos"? Será possível promover encontros micropoliticos como esse na casa do jovem e sua mãe? Será que o uso abusivo da droga pode ser elemento que faz "gritar" o sofrimento, mas que é preciso um movimento mais além do uso? Quem é ele e sua mãe? O que o SUS pode fazer para a integralidade da saúde dessa família? Não há resposta certa, mas se pode construir um espaço de encontro em que várias perspectivas se entrecruzem para se tentar forjar linhas de forças em direção à vida, qualquer que seja. Seja ela sobrevivendo num instante, em que o estar junto é fator de proteção. "Só por hoje" o encontro valeu a pena e a vida segue em acontecimento. Seja porque valeu a pena nos movermos, mesmo sem carro e de ônibus com nossos próprios recursos, rumo a casa de um jovem que opera nas rua e na casa de sua mãe algum desterritorializar morte-vida. 


\section{PONTO A: CONSULTÓRIO NA RUA: XEQUE-MATE EM REDES VIVAS}

Conforme se ponderou anteriormente, o encontro rumo ao usuário-guia a seguir apresentado teve início a partir do debate com profissionais que compõem uma equipe de Consultório NA Rua de Recife. Após três encontros, apostou-se em um processo a ser construído junto a uma pessoa em situação de rua muito emblemático para a equipe que não conseguia construir uma relação para o processo de cuidado. No geral, vários casos que a equipe cuida são difíceis de cuidar, mas esse usuário era muito difícil de acessar. Geralmente os moradores são muito expressivos, afetam demais seu entorno por conta de seu modo de estar na rua e a equipe conseguia fazer um projeto terapêutico para várias dessas pessoas. Mas não era o caso desse usuário que não parecia disponível para o contato com a equipe, nem sequer conversava com as pessoas do entorno onde ele ficava. Ficava parado durante horas em determinadas esquinas, parecendo uma pedra ou uma planta. Foi então que a equipe elegeu essa pessoa para talvez compor o processo de usuário-guia.

O primeiro dia em que conheci Pedro ${ }^{6}$, fui junto com equipe e gestora do Consultório NA Rua. Primeiro se falou com uma senhora que vende lanches que fica numa esquina. No entorno de um bairro abastado havia alí próximo um mercado, banco, lanchonete, farmácia e hostel. a senhora nos disse que Pedro estava na outra calçada talvez perto da farmácia. Atravessamos a rua muito movimentada. Será que era perigoso para ele essa travessia? Ele teria condições? Passamos como quem não quer nada para a frente da farmácia. Eu e a gestoras ficamos um pouco afastada para que dois trabalhadores chegassem mais perto e conversassem com ele. Eles falavam em um tom que, pela distância, não dava para ouvir. Depois apontaram para ele a nossa presença, dizendo que éramos da saúde e estávamos ali para saber se ele precisava de alguma coisa. Ele disse que não e nos despedimos informando que viríamos em outro dia. As únicas coisas que souberam quando foram ver quem seria essa pessoas em situação de rua, era que ele era jovem, não falava muito, e quando perguntado sobre onde morava e

\footnotetext{
${ }^{6}$ Nome fictício para preservar a identidade do participante da pesquisa. O nome Pedro significa pedra e foi assim a imagem que se falava: "ele fica ali parado feito uma pedra". Ao mesmo tempo, para essa pesquisa Pedro é também alusão a Pero Vaz de Caminha (Pero=Pedro) que foi aquele que escreveu a Carta ao Rei de Portugal comunicando a descoberta do Brasil. Fica no ar a questão: será que Pedro Alvares Cabral queria descobrir as Índias ou era um chiste político?
} 
sobre sua família, ele dizia que estava ali "esperando um amigo". Quem era esse amigo? Logo de cara pensei em "Procurando Godot", peça de teatro de Samuel Bekett, escrita no pós-guerra. É um teatro diferente das peças tradicionais. Há Vladimir, Estragon, Pozzo, Lucky e um garoto. Rubrica inicial:

Estrada, árvore, à noite (Route à la campagne, avec arbre. Soir). Em cena Estragon e Vladimir. Aparentemente esperam um sujeito de nome Godot. Nada é esclarecido a respeito de quem é Godot ou o que eles desejam dele. Os dois iniciam longo diálogo, só interrompido quando da entrada de Pozzo e Lucky. Lucky carrega uma pesada mala que não larga um só instante. $\mathrm{O}$ segundo ato desenvolve a mesma dinâmica. $\mathrm{O}$ cenário é o mesmo, apenas a árvore está um pouco diferente, agora com algumas folhas. Estragon e Vladimir iniciam sua jornada na espera de Godot. Surgem novamente Pozzo e Lucky. Pozzo está cego e Lucky mudo. Após a partida destes, aparece novamente um garoto anunciando novamente que Godot não virá, talvez amanhã. O diálogo final, que encerra o ato e a peça é o seguinte:

Vladimir: Então, devemos partir? (Alors, on y va?) (Well, shall we go?)

Estragon: Sim, vamos. (allons-y.) (Yes, let's go.)

Eles não se movem. (Ils ne bougent pas.) (They do not move.)

Como seria essa pessoa em situação de rua que é estática, quase uma pedra ou planta? De certo para mim também era uma situação uma tanto "estranha", um suposto "morador de rua" fixado em um local determinado e sem o horizonte da mobilidade.

No primeiro encontro com ele ficamos muito surpresas, eu e a gestora do Consultório Na Rua, pois ele era muito jovem. Tinha o corpo franzino. Era negro com os cabelos embaixo de um boné que, como as roupas, já mudara de cor. Também há tempos não tomava banho, além da sujeira, já estava com mal cheiro.

Em outro dia voltamos lá, dessa vez eu e a equipe ${ }^{7}$. Passamos o olho pelas esquinas e avistamos Pedro em outro lugar, em outra esquina, em uma marquise de um prédio. Pelo que vimos ali era um lugar que ele consumava ficar pois já tinha ate uma

\footnotetext{
${ }^{7}$ A partir desse momento o texto seguirá em terceira pessoa do plural. No processo da pesquisa, foram vários encontros entre pesquisadora e equipe. Pactuamos que eu sempre estaria no campo conforme a programação deles para estar com o usuário. Eu acabei sendo uma pessoa constante, mas a equipe alternava conforme a agenda dos trabalho, assim ia mudando de profissional, mas sempre na reunião semanal se falava da programação e, quando tinha agenda com esse usuário, eu era convidada a participar.
} 
cor diferente na pintura das paredes, que estava meio suja, deferente de outras partes em tom mais claro. Possivelmente porque era uma parte da construção com certa proteção contra frio e chuva.

Mais uma vez nos apresentamos e perguntamos como ele estava. Ele disse que estava bem. Perguntou-se se ele lembrava de nós e ele respondeu que sim. Perguntamos se ele havia comido. Mostrou uma lata de feijoada que havia ganhado. A senhora do cachorro quente emprestou o abridor de lata. Falamos se precisva de algo e ele disse não. Perguntamos se ele estava esperando alguém e ele falou que tinha um amigo. Perguntamos se esse amigo viria e ele balançou a cabeça que sim. Nos depedimos e falamos que em outro dia voltaríamos novamente.Ao sairmos desse encontro ficamos com a sensação que ele não falava muito. Que era para virmos outras vezes para construir uma relação com ele.

Diante desses encontros iniciais e em uma reunião de equipe foi acordado que as visitas a Pedro seriam intensificadas. Iria se organizar uma programação pelo menos semanal, em que fôssemos em diferentes dias e horários para a rua ao encontro com o usuário. Assim era uma tentativa de mapear quem eram as pessoas que construíam relação com ele. Como era o cotidiano dele nas ruas. Nessa construção de relação, também se exploraria alguma pessoa que fosse estratégica para ajudar no cuidado a Pedro. Também pactuamos que iriamos ficar junto ao usuário, mesmo que ele ficasse calado, nós também ficaríamos junto dele, mesmo que calados também. Como era essa sensação de ficarmos parados junto a ele?

Logo no início desse processo a equipe ficou sem carro. Parecia que "tinham quebrado nossas pernas". Mesmo assim a programação foi acontecendo na medida do possível. Agendávamos e nos encontrávamos em algum lugar antes para trocarmos umas ideias e íamos todos juntos ao encontro com Pedro.

Outro dia fomos eu e um Profissional Residente em Saúde Mental. Esse dia foi muito marcante tanto para mim como para ele. Em uma esquina estava ele parado. Demos "Boa tarde". "podemos nos aproximar". "Sim". Perguntamos como ele estava. "Bem". Novamente falamos que éramos do "Consultório NA Rua", que estávamos ali para estar com ele para saber se ele precisa de algo. Ele disse que estava bem. De vez 
em quando olhava para o nada e saia um sorrateiro sorriso. Ficamos então ali parados por alguns minutos e ele sem falar nada. Ficamos sem falar nada.

Notamos que ele estava com um relógio na mão. Perguntamos se ele havia ganhado e ele disse que sim. Um amigo havia dado a ele. Perguntamos que horas eram. E ele ficou meio sem saber. Dai pegamos o relógio e notamos que estava parado. Perguntamos se ele sabia que dia da semana era aquele e ele ficou meio perdido. Mas ele falou o mês e o ano. Falou o bairro que ele estava. Ficamos mais um tempo calados. Ele ficou calado. Daí as formigas começaram a subir nas nossas pernas e dissemos “Cuidado, as formigas!". Daí ele percebeu que nos e eles estávamos próximos a muitas formigas. Na despedida questionamentso "Você quer que a gente traga algo? Algum jogo? Dominó? Dama?”. Ele disse “Xadrez” (!)

Foi muito importante a nossa conversa depois desse encontro pois o Residente falou de sua angústia de ficar parado ali no silencio, numa esquina. Falei do elemento tempo. Tentei pegar esse gancho do relógio para saber se ele tinha ou não noção de tempo. E ele tinha sim certa noção de tempo. Até as plantas têm efeito do tempo pior conta das estações do ano. Ele estava vivo também e o tempo parado do relógio quebrado podia ser uma pista a seguir. Agora aquela história de xadrez nos surpreendeu por ser um jogo elaborado e difícil. E agora, como íamos fazer?

Outro dia fomos em outra composição e em outro turno. Antes de nos aproximar dele um porteiro do prédio perguntou quem éramos. Explicamos e ele ficou feliz ao saber que Pedro estava sendo cuidado. Falou que se preocupava com ele que era um menino muito jovem. Já havia oferecido para ele tomar banho no seu estabelecimento de trabalho, mas ele não queria. Falou que árias pessoas da vizinhança davam comida a ele. Havia uma senhora que sempre encomendava quentinhas ${ }^{8}$ para ele. Mas ele não queria saber de banho e só ficava na rua. Passamos a informação que estávamos acompanhado Pedro e os contatos ou qualquer informação poderia deixar com a senhora do carrinho de lanche. Perguntamos como ele estava. Ele disse que estava bem. Parecia mais receptivo muito embora não conversasse muito. Ficamos um pouco parados ao lado dele. Depois nos despedimos e falamos que não foi possível conseguir o xadrez. Iriamos tentar outro dia trazer para uma partida.

\footnotetext{
${ }^{8}$ Comidas prontas contendo uma refeição simples como arroz, feijão, macarrão e uma carne.
} 
Em outro dia e horário diferentes fomos ao encontro de Pedro. Para a nossa surpresa ele não estava naquela esquina. A moça do ponto de venda falou que parecia que ele estava na praia. Foi uma surpresa pois em um dia perguntamos se ele gostava de tomar banho de mar e ele disse que não gostava. Fomos ao encontro dele já comentando que para alguém que era uma "planta" ou "pedra" até que ele tem suas mobilidades mesmo que circule por quadras específicas de um bairro. Lá estava ele sentado no banco de costas para o mar e vendo os carros passarem. Perguntamos como ele estava. Ele disse que estava bem. "Podemos sentar?". Ele disse que sim. Explicamos que trouxemos uma surpresa: um jogo de xadrez. “Quer jogar uma partida?”. Ele disse que sim. Daí o Consultório NA Rua ficou um pouco dividido, duas pessoas sentaram no chão e ficaram olhando as jogadas (essas sentadas não entendiam absolutamente nada de jogo) e uma pessoa, o profissional residente, jogou a partida. Foram então se passando os minutos e Pedro a jogar com o Residente. Peça ia, peça voltava. E eles lá, jogando. Parou ao nosso lado um vendedor ambulante. Ficou olhando por uns minutos e depois se foi, sem falar uma palavra. Depois passou uma família passeando com o bebê, parou, olhou rapidamente e se foram. O residente e Pedro jogando, a pesquisadora e a profissional olhando. A brisa do mar nos nossos cabelos. Algumas peças balançando com o vento. Mas o jogo acontecendo. E o silêncio. Mas as peças iam lá e cá. Foi cerca de uma hora esse processo, o silencio. O vento do mar. Eles jogando. Até que Pedro ganhou a partida. Depois ganhou outra. A hora foi se passando e chegou a hora de irmos. Falamos que foi muito bom o jogo com ele. Que ele ganhou e nos surpreendeu. Perguntamos se ele precisava de alguma coisa e ele disse que não.

No jogo de Xadrez, Xeque mate é uma jogada que representa o final da partida. Nesta situação, o rei não pode ser coberto por nenhuma outra peça do jogo e nem mover-se para nenhuma outra casa sem ser tomado por uma peça do adversário. Quando acontece apenas o "xeque", o rei está ameaçado, mas ainda pode escapar. Mas quando ocorre o xeque mate, o rei está encurralado e por isso o jogo chegou ao fim. O xeque mate desse jogo entre a gente que trouxe um deslocamento para outra perspectiva de cuidado no encontro. O xeque mate desse jogo nos deslocou para uma trama dos deslocamentos, das forças que estão em cada peça, mas que são mesmo potentes quando estão em uma jogada. O Xeque mate dele foi um deslocar do nosso olhar para com ele e ele perante o nosso olhar. Era o acontecimento enquanto virada para um outro plano dos possíveis. 
Esse foi o dia foi muito especial pois nosso deslocamento foi intenso. Pedro era inteligente e ficou conosco jogando. Nossa relação com Pedro foi através do jogo. Ele também tem seus deslocamentos por entre as equinas daquelas quadras. Não tem nada. Só uma mochila, as roupas, mas consegue de várias pessoas o necessário para sua subsistência. Um dá quentinha, outro oferece um banho, outro deixa um dinheirinho para ele comprar alguma coisa que necessite. Conversando com o pessoal do entorno também soubemos que tem uma pessoa que o ajuda com algum dinheiro para ele comprar comida. E ele vai comprar e só pede o necessário. Ele se desloca em poucos metros, mas desloca o necessário perante seu desejo. Ele é um estrategista do deslocamento, operando os traços conforme o necessário e conforme as peças que se apresentam a ele.

Certo dia partiram a agente social e a pesquisadora para o encontro com Pedro. O período foi um turno da manhã. Ele estava em outra esquina, em pé em uma calçada. Os pés estavam inchados e ele estava estranho, mais calado que o habitual. Dessa vez a abordagem foi um pouco mais diretiva, talvez pela peculiaridade da profissional do Consultório NA Rua. Ela falou com ele e perguntou se ela a reconhecia. Ela havia feito algumas aoes com ele mais estava de férias e havia retornado. Também mudou o visual porque ela cortou o cabelo, mas era a mesma profissional que havia estado com ele anteriormente. Ele perguntou se Pedro estava bem. Ele disse que sim mas com certa má vontade ao responder. Perguntamos se havia acontecido alguma coisa e ele disse que não. A agente falou que achava que os pés dele estavam inchados. Pediu para pegar nos pés dele e ele deixou. Ela pegou e de fato estavam inchados. Ela falou que não faríamos absolutamente nada que ele não quisesse. Ela perguntou se ele tinha se alimentado e ele disse que sim. Perguntou se ele queria água e ele não falou nada. Ela falou que tinha na bolsa um lanche que estava fechado mas que iria deixar com ele. Em seguida apareceu um senhor na rua que falava que ele era jovem, que podia estar em oura situação. Parecia que já conhecia Pedro há um tempo. falou que tentou levar ele dali para um tratamento porque essa não era vida para um rapaz jovem como ele. Não era bom ele estar na rua pois corria riscos. A rua tem muitos riscos. falou que ate pensou que ele poderia ir ser cuidado em uma instituição de saúde. Nesse momento nos divisimos, a trabalhadora chamos de lado o senhor para saber de suas ações junto a Pedro e eu fiquei com Pedro conversando sobre amenidades, se ele estava bem, dormiu bem, se precisava de algo. Depois ele voltou e disse que depois conversava comigo. 
Continuamos a conversar com Pedro. A agente perguntou se poderia abrir a bolsa dele. Se ele não quisesse ela não faria, mas queria ver se estava tudo cero com a bolsa e os pertence dele. Ele permitiu para minha surpresa pois pensava que aquela bolsa podia ser uma extensão dele e um movimento assim seria um tanto arriscado. Mas Pedro permitiu e ela fez essa ação na frente dele. Feito uma mae, falou que não se coloca escova junto de roupa porque pode ser ruim, além de perder poder trazer alguma sujeira para a escova. Ao sairmos de lá falamos que Pedro podia contar com a equipe do Consultório NA Rua, que eles iriam fazer apenas o que ele permitisse. E finalizou dizendo que outro dia voltaríamos para saber como ele estava.

No caminho de volta um porteiro de outro prédio nos abordou. Explicou que Pedro era um "menino bom”. Que ele também se ofereceu para que ele tomasse banho lá no prédio. Várias pessoas do prédio também ajudam e que deixariam Pedro tomar banho caso necessário. Também já teve vontade de pegar ele mesmo sem o consentimento, mas não o fez. A trabalhadora então explicou todo o trabalho do Consultório NA Rua e disse que estavam cuidando dele, mas é algo processual, construído gradativamente. Foi então que ela explicou o trabalho que desenvolviam ilustrando o caso do "Conheço Não" (já referido anteriormente). É muito delicado esse trabalho por ser construído paulatinamente. Mas é possível mesmo com tantas adversidades e com pessoas tão fragilizadas. O porteiro falou que entendeu o trabalho da equipe de saúde e se precisassem poderiam contar com ele.

Essa conversa entre a trabalhadora e o porteiro me intrigou. Mesmo que fosse diferente entender o trabalho como esse da atenção à saúde de pessoas em situação de rua, eles falam do trabalho referenciando a singularidade e a delicadeza do cuidado construído aos poucos e a cada encontro nas ruas. Mesmo em situações absurdas por não ter certa "lógica" eles vão (re)construindo os vínculos rumo ao cuidado. Cada caso é um caso e para expressar esse fazer, era importante referenciar os processos de cada linha de cuidado construído nas ruas. E qualquer apoio possível é estratégico. Assim, mesmo que a equipe tentasse correr atrás de saber da história de Pedro, de onde ele vinha, porque estava nas ruas, quem seria esse tal amigo que ele sempre esperava, se ara o Conselheiro Tutelar envolvido no processo de tentar construir lações familiares (até essa informação a equipe havia conseguido na relação com Pedro), todo esse caminho se constrói ao caminhar. Esse modo de fabricar cuidado é uma aposta na linha de 
cuidado singular. Cada usuário em situação de rua vai apontando vários pontos de apoio construído nas ruas, pontos tão anônimos mas espalhados, não tão semelhantes a uma família situada numa casa, em um endereço, mas presentes na solidariedade.

Também aqui nesse momento lembrei que esse falar sobre o cuidar na rua, que fala de novo, de novo, de novo... dialogando com tantas pessoas que atravessam esse cuidar nas ruas também parecia com o meu fazer de cartógrafa numa pesquisa cujo método é o encontro. O caminhar rumo a usuário-guia é estar sempre falando de novo...de novo... e de novo sobre o que é essa pesquisa interferência. Muitas pessoas passam e deixam um pouco de si na construção de um cuidado que segue até onde se possa seguir com a pactuação sobretudo com o usuário e também com apoio de tantas pessoas afetadas por ele.

Outros encontros se seguiram e outros partidas de xadrez foram uma marca de dialogo entre os cuidadores, os técnicos de referencia, pois a equipe era referencia e não um só trabalhador. Também outros profissionais residentes acessaram Pedro em seu processo de formação em serviço.

Em um desses caminhar do Consultório NA Rua junto a Pedro, foi a tentativa de acionar o CAPS de área que pudesse cuidar de Pedro nas ruas. Foram várias idas e vindas da equipe do Consultório NA Rua para acionar uma visita de algum profissional do CAPS fizesse uma primeira escuta de Pedro na rua e mesmo e para ajudar a construir um processo de cuidado a partir da rua. Também havia preocupação clínica pois não se tinha conhecimento de como ele estava clinicamente. Havia vezes que Pedro ficava horas em pé, ou relatavam que em várias noites ele ficava sem dormir parado por horas nas esquinas. Mas durante vários meses a equipe do Consultório Na Rua referencia para Pedro não conseguia acessar o CAPS. Também tentaram acionar algum médico da unidade básica onde a equipe contava como ponto de apoio e "visita" não está nos serviços ofertados. A equipe até relatou que em um desses processos de idas e vindas chegaram a entrar em um movimento em que a orientação "da rede" foi realizar uma internação em um hospital psiquiátrico para que Pedro pudesse ser avaliado clinicamente e por especialistas da psiquiatria. A pressão do momento foi tão impactante que eles se viram caminhando por esse via, mas acabaram recuando no próprio processo. Os atravessamentos e capturas de forças molares são mesmo silenciosos ao mesmo temo em que há um escapar nessa trama de forças micropolíticas. 
Tantas foram essas idas e vindas que a gestora acabou construindo uma via de contato na rede de atenção psicossocial através de um hospital geral com leitos psiquiátricos, os chamados leitos integrais em hospitais gerais. Foi então promovido um encontro envolvendo uma apoiadora da Secretaria de Saúde de Recife que atua na gestão desses leitos integrais, profissionais do Hospital Geral com leitos integrais para saúde mental, gestora, trabalhadores e Residente do Programa de Residência em Saúde Mental da SESAU, que é enfermeira, e eu também fui convidada por estar nesse processo de interferência para construção de cuidado integral para Pedro. Foi muito interessante a construção desse espaço de dialogo, construído em um movimento instituinte para um cuidado e o dado analisador foi que nesse espaço não havia representante do CAPS de referencia na área de Pedro. Essa lacuna foi apontada na conversa.

Em um primeiro momento a apoiadora dos leitos integrais explicou como era a construção dos leitos integrais para saúde mental. Há um hospital geral na rede de saúde de recife que possui leitos integrais para saúde mental para casos em que há uso abusivo de álcool ou outras drogas, que foi definido assim pelo perfil tecnológico de profissional e perfil hospitalar. Há outro hospital geral que tem leitos integrais em saúde mental para casos mais característicos de crise psiquiátrica sem se caracterizar pelo abuso de álcool ou substância psicoativa. A reunião ocorria nesse segundo hospital. Esse dado acabou levando a gestora do Consultório NA Rua a acionar essa via de acesso. Se o CAPS não conseguia ir talvez o usuário pudesse acessar um hospital geral com leitos integrais para casos como o dele.

A reunião foi muito significativa porque as pessoas puderam ouvir a Equipe do consultório NA Rua falar de Pedro. Puderam também falar do porque não conseguiam acessar o CAPS que não saia para uma visita na Rua para conversa e construir um cuidado singular para Pedro na rua. A equipe pontuou que era a responsável por Pedro e estavam buscando construir esse cuidado na rua e vinham percebendo uma mudança na relação com o usuário, já estava sendo construído um vínculo, mas necessitavam de ajuda para que Pedro tivesse um cuidado integral: por que ele não dorme? A perna inchando seria algum sinal de algum problema clínico? E as dificuldades de comunicação teria alguma relação com processos produtivos de seu adoecimento mental? Pedro não é uma psiquê parada nas esquinas, ele tem um corpo que não é 
sequer tocado para exames clínicos? Por que a rede não esta junto com o Consultório $\mathrm{Na}$ Rua para construir um projeto terapêutico para Pedro?

Varias pessoas nesse encontro puderam falar dessa dificuldade de acesso para alguns casos "silenciosos" da saúde mental. Muitas vezes o louco que quebra tudo, que barbariza no seu acontecer-surto chama atenção dos serviços que se "mexem" de alguma maneira para construir alguma via de atenção. Mas quando há alguém como Pedro, que fica parado e silencioso, quase uma planta, esses ficam sem ser visto. Os serviços são acionados pelo surto-acontecimento mas diante da pessoa parada, eles não são acionados, apenas quando há uma família que aciona, se não eles possivelmente não vão ao encontro dessas "pessoas-vegetais". E o que é mesmo "situação de crise"? Será que está relacionada a situações do "Louco muito louco" que vai quebrando tudo, os demais casos são invisíveis pois não se está mexendo com ninguém.

A apoiadora dos leitos integrais em hospitais gerais para saúde mental reconheceu que o cuidado está sendo processado nas ruas e a equipe do Consultório na Rua é a equipe de referencia para cuidar de Pedro. Foi construído um processo de cuidado e vinculo entre Pedro e o Consultório. Contudo, situou que é preciso tensionar o CAPS para que se mova ao encontro de Pedro na Rua. Também contextualizou que o CAPS tem um papel importante nesse cuidar em RAPS. Pedro não tem perfil para vir ao hospital geral com leitos integrais para saúde mental porque esse deslocar dele do lugar onde ele está, na rua, pode até prejudicar o seu processo de cuidado que está em construção e caminhando a passos largos, pelo que se ponderou no grupo. Os equipamentos da RAPS tem que ir para as ruas cuidar também quando necessário.

Ela em sua experiência em saúde mental lembrou que esses casos de pessoas com algum transtorno mental que não fazem nada do acontecer de crise em saúde mental (tipo louco muito louco) acabam ficando à margem de qualquer cuidado. Ele lembrou de um caso de uma jovem mulher que ela atendeu em um hospital que ela trabalhava que estava com graves problemas no útero, em estado tão grave de infecção que estava em estado de purulência. Esse relato foi muito comovente, é como se o sofrimento mental silencioso chegou à via mais dolorosa a ponto de comprometer uma parte tão emblemática do corpo daquela mulher, que implodia em sofrimento. Mesmo ela tendo passado por vários serviços de psiquiatria, o seu corpo era invisível. A apoiadora ainda pontuou que em muitos casos de internação psiquiátrica, o corpo é 
esquecido. Onde fica a integralidade do cuidado na saúde mental? O corpo é mais um chiste para a saúde mental tal como a integralidade.

Foi importante aquele conversa por ser um espaço de diálogo e construção de conhecimento para operar algum caminho de cuidado para o prosseguir de Pedro nessa rede. Iria ser tensionado o CAPS para participar desse cuidado na rua que já é operado pelo Consultório Na Rua. Também se aproveitou que havia uma residente em saúde mental que é enfermeira para que ela, em seu processo de trabalho, também busque abordar Pedro no sentido dos primeiros elementos para o olhar para esse corpo na rua.

Uma das últimas ações da pesquisa junto a Pedro foi um encontro em que eu pudesse agradecer e me despedir dele, falar da potencia do encontro, que aprendemos muito com ele, que eu gostaria de desejar felicidades. A equipe continuará o cuidado com ele, mas eu não estarei lá. Foi muito importante esse momento que a equipe promoveu. Foi breve e intenso. Queria dar um presente de agradecimento ao mesmo tempo que o presente fosse um dispositivo-ponte para outros encontros. Ele que já é tão presenteado pelos anônimos das ruas seja com roupas, escova, um trocado para o lanche, também poderia usufruir de um presente-ponte-para-encontros.

Nesse dia chegamos de tarde, ele estava em uma esquina, sentado, com o olhar no horizonte, por entre os carros indo e vindo. Passou um filme na minha cabeça, do primeiro dia, do encontro a beira mar, da virada de nossas vistas sobre ele que nos surpreendeu e nos mudou a ponto de provocar outras possibilidades de cuidado. Até em casa, quando chovia muito eu pensava nele, que poderia estar na chuva, mas ao mesmo tempo confiava na astúcia do jogador.

Em um dos encontros para fechamento do campo de pesquisa se propôs que os trabalhadores e gerente do Consultório NA Rua, pesquisadores locais da RAC Recife, trouxessem alguma "coisa" que falasse de Pedro nos processos que ele gerou em cada um e em nós. Com esses objetos construiríamos um diálogo sobre como nosso coletivo compreendia esse trajeto rumo ao objeto redes em saúde a partir de múltiplas perspectivas.

No dia do encontro, uma caixa sobre a mesa, e cada um foi falando do seu objeto. A gestora foi a primeira a falar. Trouxe o prontuário de Pedro, que é um objeto 
de uso cotidiano no processo de trabalho do Consultório NA Rua mas que o acesso a informações desse objeto não levava a quem era Pedro. Construir um caminho com Pedro foi muito intenso, desde o desafio da escolha de que ele seria o usuário-guia do Consultório, até os caminhos e descaminhos que tiveram que enfrentar em todo o processo de cuidar de Pedro NA Rua. Essa perspectiva gera questionamento: Como construir dispositivos do cotidiano do trabalho que tragam essa dimensão das afecções para ampliar os modos de caminhar do usuário em redes vivas?

A outra técnica, psicóloga, afetuosa em vários momentos desse trajeto com Pedro, trouxe uma figura de uma árvore com diversas partes de imagem de papel, que articulados configurava uma árvore. Falou que ela gosta muito dessa árvore, que foi dada por uma irmã e que fica em local de destaque em sua sala de casa. Abrindo a tal árvore ela foi lembrando dos primeiros contatos com Pedro que era um usuário intrigante por ser diferente dos outros usuários do Consultório NA Rua. Os outros ele conseguiam construir um território de diálogo e ação, com Pedro, parado na esquina e calado eles não estavam conseguindo agir. Era tamanha a frustração que foi consenso a escolha de Pedro para usuário-guia. E como ele surpreendeu a todos quando escolheu o xadrez para jogar conosco. Mais ainda quando foi através do jogo que se pode acessar um espaço de troca com ele (grifo da autora)

O outro profissional lembrou que foi um desafio escolher um objeto que falasse de Pedro e do nosso processo construído com ele. Falou que semanas anteriores havia estado em um espaço com Antônio Nery, uma das referencias para ações e teorizações sobre redução de danos. Explicou que Nery estava em uma sala repleto de várias pessoas de diferentes serviços que trabalham com saúde mental e com redução de danos e primeiramente pediu para que as pessoas escolhessem uma pessoa que consenso de todos por desestabilizar a rede de saúde mental (lembrei logo do desafio da escolha do usuário-guia). Depois do alvoroço das pessoas, elegeram uma usuária com muitos problemas de saúde mental, drogadição, desestruturação familiar e social, que circulava em vários serviços mas que as pessoas não sabiam o que fazer com ela. A partir dessa escolha, ele perguntou “quem é essa pessoa?”, “quem é ela?”. Daí as pessoas foram falando que ela tinha problemas de drogadição, que tinha um quadro de (citaram nosologia), que participou de tal e tal ação em um determinado serviço...O palestranteprovocador então falou "Vocês falaram sobre o adoecimento dela, sobre as ações 
desenvolvidas nos serviços de saúde e tantas outras coisas, mas vocês falaram quem é fulana?". Diante dessa provocação que inquietou esse grupo de trabalhadores e gestores o profissional do Consultório, consigo mesmo, lembrou de Pedro.

Ele então resolveu trazer um envelope para falar de como foi essa "aventura" de construir um processo de cuidado com Pedro rumo a redes vivas em saúde. A forma como Pedro chegou ao Consultório NA Rua foi como um envelope que chega nas mãos de uma pessoa, alguém remete a um destinatário alguma coisa. Tal sensação era como um despacho, uma entrega. Diante desse envelope, quando ele abriu, havia um papel em branco. As pessoas não sabiam quem era Pedro, nada escreveram sobre a relação construída com ele. No final desse processo com Pedro, aos poucos puderam construir outras possibilidades de cuidado e sobretudo estavam construindo um cuidado na rua.

Diante do desafio do objeto que falasse de Pedro pensei nos diferentes planos de sensações que ele provocou em mim. Primeiro por ser uma pessoas em situação de rua que se julgava ser uma "planta" ou "pedra" parado em uma esquina. O meu devisnômade não conseguia entender aquela imagem. Depois no estar em silencio como um território de encontro ${ }^{9}$, só por estar lá. Se ele era visto como planta então vamos ficar lá parados como planta também. Mesmo que eu seja nômade, o silêncio e o estar parada eram estratégias que valiam a pena pelo possível encontro com Pedro. Daí veio o relógio com ponteiros que não andavam, as formigas subindo na gente, o xadrez, o jogo na beira mar e o xadrez.

Eu, pesquisadora em interferência no encontro com tantos olhares, levei uma espécie de caderninho com diferentes tipos de papeis (carbono, papel seda, papel ofício, lixa, celofane, papel madeira, E.V.A emburrachado com purpurina, papel cartonado, papel transparente, alguns tipos em diversas cores). Esses tantos papeis buscava fazer referencia aos caminhos que percorremos para acessar Pedro com tantas capas de crostas de proteção impressas na pele.

Falei que foi uma grande aventura esse processo construído com a equipe do Consultório NA Rua rumo ao encontro com Pedro. Fui muito afetada por esses

\footnotetext{
${ }^{9}$ Essa estratégia de ficar perto só por ficar partiu de Laura que lembrou de um caso em que o encontro entre uma profissional de saúde e uma pessoa com transtorno era quando a profissional se sentava e a pessoa ficava pegando em seus cabelos durante minutos e minutos. Essa cena se repetiu por tantas vezes até que um dia algo diferente aconteceu.
} 
atravessamentos dessa vivência. Acabei me deparando com um momento de fechamento de um processo de pesquisa, o meu doutorado e a RAC, e esse momento traz um turbilhão de afetos. Ficará saudade da convivência com a equipe, as conversas anteriores a ação com Pedro e as posteriores em um café na esquina próxima à área de Pedro, o dividir o taxi para irmos juntos conversar com o pessoal do Consultório DE Rua, a saudade do carro e a indignação por terem "cortado nossas pernas", mas não cortaram pois construímos juntos outras possibilidades.

Lembrei da estratégia de irmos em diferentes momentos do dia e início da noite para chegar até Pedro. Assim as crostas de Pedro foram assumindo outras cores e sensações. Crosta é para proteger. Para se misturar ao ambiente em mimetismo as crostas servem, mas não signifique que Pedro não tenha outras cores em seu estar naquelas esquinas. Daí o plano de vários horários de visita para o encontro foi potente e pudemos construir outras vias de tempo-espaço diante dessa pessoa-parada. Daí a necessidade de papeis de várias tonalidades e texturas pois foi assim que as tonalidades e texturas de Pedro me afetaram.

Agora o compromisso da escrita acadêmica de levar esses atravessamentos e afetos a uma encadernação que articule conceitos vivos era um compromisso de compartilhar na academia em rede de produção os afetos e efeitos dessa pesquisa interferência. Por isso também encadernei os papeis, os planos e os papeis foram de muitas texturas e afetos e eu estava no desafio da escrita de muito do que vivi e vivemos. Meu "tesear" assumia um compromisso ético-estético-politico com Pedro, com eles e com os demais que contribuíram com essa produção. Os planos são amplos, mas há o molar e molecular em incessante luta de forças no cotidiano micropolitico da vida. Escrever algo, encadernar escritos, também é uma aposta micropolitica, também é colocar o território desse tensão do molar e molecular na produção de conhecimento.

Também mostrei o jogo de xadrez como um dispositivo de abertura ao encontro mas que foi acessado através do encontro. O xadrez, eu continuo sem ter muita paciência para jogar xadrez mas visualizo a potencia desse dispositivo para outras possibilidades de encontro. Daí mostrei um jogo de xadrez pequeno que comprei pensando nessa vivência das redes vivas nas ruas. Esse jogo eu queria era entregar a Pedro quando fosse fazer a despedida e agradecimento em nome dos estudos. 
Em outro dia a equipe agendou nossa ida para uma visita a Pedro. Chegando lá falamos boa tarde. Ele disse boa tarde. Mesmo ainda reservado era um outro Pedro. Apertava a mão e arriscava olhar sorrateiro para a gente. Perguntamos se estava tudo bem e ele disse tudo bem. Depois perguntamos da bolsa dele e ele disse que jogou fora. Apontou para um bueiro na mesma equina. Fomos ver e lá estava a bolsa dele. Ele agora não tinha nem a bolsa. "Por que jogou a bolsa?" e ele calado. Perguntamos se ele tinha comido e ele disse que sim. Perguntamos se ele gostaria de falar da história da bolsa e ele falou que não. Daí falamos umas frivolidades, sobre o tempo e a rua. Depois eu falei que era meu último dia junto à equipe do Consultório NA Rua, que aprendi muito estando junto da equipe que cuidava dele. Ele nos ensinou muito e eu gostaria muito de agradecer. Assim havia trazido um presente especial para ele: um jogo de xadrez pequeno, que cabia no bolso, parece até que eu estava adivinhando pois bem que ele pode colocar no bolso para não perder. Além de pequeno, o jogo também tem as peças de imã assim não vão sair voando ao vento atrapalhando as jogadas. Ele ainda poderia usar o jogo para convidar as pessoas para algumas partidas. Foi muito legal pois ele logo pegou o jogo. Fui abrindo e mostrando essas características: pequeno, imã, tabuleiro dobrável e facilmente levado no bolso. Para a nossa surpresa, era o primeiro dia que dois Residentes de saúde Mental ad SESAU estavam lá e um deles jogava xadrez. Ótimo porque nem eu e nem o pessoal do Consultório ali sabiam. Então Pedro foi jogando, a gente sem entender muito o que estava acontecendo, eles foram jogando e Pedro ganhou...depois outra partida e Pedro ganhou de novo. Rimos juntos dessa perspicácia de Pedro que surpreendeu o Residente. Muito bom uma despedida marcada por risos em uma partiga em que o jogador ganha o xadrez, mas todos ganham no encontro.

Se o amigo dele virá? Não sabemos quem era o amigo, só sei que ele depois não mais falou do amigo. no ultimo encontro que tive com os colegas do Consultório $\mathrm{Na}$ Rua para o fechamento para a construção de escritos da RAC, soube que a residente enfermeira estava começando a fazer o cuidado no acesso ao examinar do corpo de Pedro. Ele ainda estava com o jogo, muito embora ainda estivesse sem bolsa, mas possivelmente guardava no bolso mesmo. E nesse dialogo uma das técnicas não de onde havia vindo o joguinho de xadrez e quando perguntou a ele "quem deu?": "uma grande amiga minha". Todos nos olhamos nesse momento e meu coração ficou cheio de felicidades. Sei lá o que vai ser desse doutorado ou dessa RAC, mas aprendi que 
naquelas quadras, sem saber jogar, tudo valeu a pena pelo encontro. Aquelas quadras são mesmo atravessadas pelo rizoma dos tantos amigos que podem cuidar fora de muros, mesmo quando se adota algumas quadras na espera de um amigo que não vem, mas tantos outros passam...passam...passam.

Nas jogadas do xadrez, xeque mate é do rei, mas que só é rei por tantas peças e por tantos movimentos por entre tantas peças e tantas jogadas. Nem sempre o que se vê parado se está estático pois há deslocamentos promevidos em pequenos e quase imperceptíveis encontros. Assim Pedro nos deslocou assim como nós o deslocamos. Os rizomas vão acontecendo. 


\section{PONTO B: AS VISTAS RUMO A UM PONTO NÔMADE ADSCRITO EM TERRITÓRIO DE MORTE-VIDA}

Giz

Legião Urbana

E mesmo sem te ver Acho até que estou indo bem Só apareço, por assim dizer

Quando convém Aparecer ou quando quero

Quando quero Desenho toda a calçada Acaba o giz, tem tijolo de construção Eu rabisco o sol que a chuva apagou Quero que saibas que me lembro Queria até que pudesses me ver És, parte ainda do que me faz forte E, pra ser honesto Só um pouquinho infeliz Mas tudo bem Tudo bem, tudo bem... Lá vem, lá vem, lá vem De novo Acho que estou gostando de alguém E é de ti que não me esquecerei Tudo bem, tudo bem... Eu rabisco o sol que a chuva apagou

Tudo bem, tudo bem... Acho que estou gostando de alguém Tudo bem, tudo bem...

A construção do caminho até a usuária-guia foi marcado por muita intensidade de encontros e reencontros entre muitas pessoas. Em um primeiro momento da pesquisa o CAPS ao qual a usuária construiu uma relação não estava apontado no primeiro momento. Contudo como o "enquadrilátero" foi uma aposta nesse estudo, acabou se chegando a essa usuária. 
Assim, depois de vários debates no grupo RAC Recife, acabou se acordando que seria potente um estudo de redes em saúde no CAPS em questão. O mesmo foi escolhido para participar do estudo em virtude de ser campo de prática de uma profissional residente do Programa de Residência em Psiquiatria da SESAU. Esse programa tem a especificidade de que o profissional residente permanece por um ano dividindo suas ações no programa em CAPS e em hospitais gerais com leitos em psiquiatria. já que a profissional residente estava há vários meses no referido CAPS, acabamos por pactuar essa entrada nesse campo de pesquisa.

A partir dessa primeira decisão se procedeu com o caminho estabelecido pela SEGTES/SESAU, primeiro contato foi com a profissional de referencia do Distrito Sanitário onde se localiza o CAPS. Essa contextualizou brevemente a rede naquele território. Falou dos serviços de saúde mental e pontuou que o serviço em que se pretendia realizar o estudo era acolhedor a propostas de estudos. Em seguida marcou-se uma conversa com gestoras do CAPS, gerente geral e gerente clínica para se explicar o que era a pesquisa, se poderia ser realizado o estudo lá e em que condições.

A seguir, os escritos serão apresentados em primeira pessoa, pois se refere à construção dos efeitos desse primeiro contato com o CAPS, que foi um dos serviços em que a pesquisadora atuou como estagiária em uma época passada.

Os caminhos que me levaram a esse CAPS não foram previamente construídos, foi um acontecimento provocado pelos encontros construídos através dessa pesquisa de doutorado e na RAC. Eu já havia passado por esse CAPS em minha formação. Trata-se de um serviço que tem uma história de acolher vários profissionais em formação. Será que as pessoas que conheciam continuavam lá? Como estava o serviço? E será que os usuários que conheci estavam por lá também?

Primeiramente eu me perdi no caminho. Estava indo em direção ao antigo endereço que o CAPS funcionava, talvez como um movimento em que o passado provoca certo tumulto no nosso agir do momento. Ao ligar para a gerente ela me reorientou quanto à localização atual do serviço.

Chegando lá falei com a segurança e ela foi me levando até a gestora do lugar. Havia algumas pessoas sentadas na recepção e outras conversando nos demais setores 
da casa. Parecia um: sofás, mesa, televisão. No primeiro andar havia outras salas e fui levada ate o setor da gerencia. Achei o espaço bem organizado para uma primeira vista.

$\mathrm{Na}$ sala da gerencia, rostos familiares. A gerente e a gerente clínica estavam numa reunião interna. Me apresentei rapidamente e pedi desculpas pelo pequeno atraso que ocorreu porque tive dificuldade em me localizar. Falei que reconheci ambas pois havia sido estagiária de lá há alguns anos. Foi então que a gerente falou que lembrava de mim. Que eu havia participado ativamente de uma festa importante que houve lá. Pensei "como é bom ser lembrada por momentos tão especiais".

Contextualizei a pesquisa que estou participando como pesquisadora bolsista a RAC. Falei também do meu doutorado. Essa primeira parte é importante porque situa todas as partes envolvidas sobre as linhas gerais do estudo, da importância para o envolvimento das pessoas na construção dos próximos passos a serem dados.

Senti-me muito acolhida, mesmo com varias perguntas sobre o estudo "diferente" daqueles "tradicionais". Destaquei que o caminho da pesquisa fazemos ao caminhar, ao interagir com as pessoas. Falando no processo da pesquisa, apontei para o usuário-guia, que será escolhido por eles. Eu não vou escolher o usuário, mas a equipe é quem vai escolher e esse processo de escolha, os argumentos, lembranças sobre as pessoas usuárias do serviço, já seriam elementos que apontam para o modo como a assistência vem ocorrendo.

Acordamos então a apresentação da pesquisa em linhas gerais. E em outra reunião faríamos o debate sobre um usuário. Eu iria tentar conversar com diversas pessoas que participaram do processo de cuidado do usuário em rede e também conversaria com esse usuário. Era muito importante os vários pontos de vista de pessoas que participaram do cuidado para entender redes nesse modo de pesquisar redes de saúde

Nesses estudos de rede venho (re)conhecendo as marcas do tempo-espaço que vai desenhando suas marcas em mim, no meu corpo em um movimento de conhecerdesconhecer um caminho ao caminhar. Como é bom se reconhecer nessa rede viva, através de bons encontros de outras épocas. Mesmo com o entra e sai de pessoas, alguns reencontros com produção de efeitos potentes para a vida. Por conta desse bom encontro 
com essas gestoras senti um clima de receptividade na pesquisa. eu não era tão estranha assim. Lá estava eu me reencontrando com o passado-presente-futuro de pessoas que há tempos estão atuando em serviços de saúde mental como CAPS.

No dia marcado, cheguei na hora agendada. Mas a equipe continuava em reunião a portas fechadas. Fiquei esperando na ante sala. Depois se seguiu o lanche, já fui reconhecendo outros rostos familiares. Falei com algumas dessas pessoas. Alguns me reconheceram. Fiquei feliz. Depois eles voltaram para a reunião e a gerente explicou que eu iria me apresentar e falar da pesquisa. falei brevemente quem eu era, o que era a pesquisa. Falei da Residente em Psiquiatria que já acompanha o grupo da RAC Recife. Ela também estava presente nesse momento. As pessoas, no geral, mostraram-se receptivas, alguns conversavam em paralelo ou acessavam o celular, mas uma grande maioria falou que era importante uma pesquisa sobre redes em saúde mental.

Quando expliquei sobre usuário-guia eles perguntaram se poderiam conversar entre eles antes para pensarem no usuário. Eu disse que esse processo de escolha é construído no caminhar e se eles costumavam fabricar momentos de grupo e esse tipo d produção coletiva poderia ser construído nesses espaços, por mim tudo bem. Essa forma de processar o trabalho também é um dado para o estudo.

No dia agendado, em um espaço dentro da reunião de equipe foi o debate sobre o possível usuário-guia que eles haviam escolhido. Haviam pensado em alguns nomes. Teve um certo alvoroço sobre a decisão final, mas depois todos colocaram que seria uma usuária muito emblemática para o serviço.

Geralmente peço permissão para o grupo gravar esse momento de escolha do usuário para depois escutar novamente os diálogos. Mas nesse momento a profissional que era técnica de referencia dessa usuária pediu para não se gravado pois era um caso que havia uma séria situação de vulnerabilidade. A usuária estava numa situação de ameaça de morte na comunidade onde residia. Falei que respeitava essa decisão do grupo e que tomaria todos os cuidados para garantir o anonimato das pessoas envolvidas. Diante disso a usuária será denominada por um pseudônimo e a seguir se pretenderá construir um relato que preserve esse anonimato das pessoas envolvidas. Vamos chamar a usuária de Maria. 
A técnica então fez um breve e intenso resumo do caso. Situou que a usuária foi foco de intenso estudo na unidade. Várias reuniões de supervisão clínica abordaram os elementos clínicos que atravessam o cuidar dessa usuária, que mobiliza demais o grupo por sua reatividade. Maria só fazia o que ela queria. Ela "causava" na unidade com algumas ações de extrapolar limites de acordos estabelecidos. Era "inadequada" em várias formas de lidar com o outro na unidade.

A técnica estava com o prontuário na mão e explicou que, se precisasse recordar na hora, teria como acessar alguma informação. Mas não recorreu a esse prontuário. Falou sem hesitar vários dados desse caso.

Falou que esse era um "caso de sucesso" por ter sido muito bem investido pela equipe tanto nos diversos atos em que a equipe se prontificou a atuar, como também foi um caso também trabalho em diversas reuniões de supervisão clínica.

Era uma mulher de quarenta e poucos anos. Com três processos de tratamento no CAPS. Teve quatro filhos. Dois deles foram assassinados por conta da situação de risco na comunidade em que ela mora. Perdeu um filho para a adoção, sendo que essa ultima situação foi bem acompanhada pelo CAPS em parceria com Equipe de Saúde da Família em que a usuária era também usuária. Recentemente o marido dela faleceu por infarto fulminante. $\mathrm{E}$ o filhos mais velho, que aparentemente nada tinha a ver com o mundo do crime acabou assassinando uma pessoa familiar do assassino de seus irmãos. Estava então foragido. Os trabalhadores temiam pela segurança também deles.

No momento dessa reunião a usuária estava para receber alta do hospital geral onde estava em leito de atenção à crise. Muito embora várias pessoas reconhecessem que a internação não era por questões psiquiátricas, mas por uma questão de segurança. Não queria que ela voltasse à comunidade onde ela moraca pois corria risco de vida. Nesse ponto a profissional residente, que também atuava no hospital referido, explicou que a usuária não estava em uma situação de crise psiquiátrica, estava até organizada para quem teve situações de perdas tão avassaladoras em sua vida.

A técnica de explicou que ela terá alta em breve e não sabe s o CAPS poderá ajudar pois ela não tinha uma demanda para o CAPS. Ela considerava que a usuária estava até organizada. Ela mesma teria enlouquecido se tivesse vivido perdas tão cruéis. 
Mas não sabia o que fazer. Acreditava que esse caso poderia ser estudado como caso de usuário-guia porque só mesmo a rede para ajudar uma pessoa na situação de Maria. Não sabia nem se apenas a rede de saúde dá conta, mas que também deverá atuar outros serviços da área social e da justiça.

Lembrou que esse caso foi considerado de sucesso pois houve uma participação muito intensa de trabalhadores do CAPS que atuaram em conjunto com a Equipe de Saúde da Família que é a que está perto do território onde vive a usuária. A própria equipe da USF ponderou sobre o risco da comunidade.

Iria tentar articular algum abrigo para a usuária até resolverem a situação dela. Quem da família restou para ajudar? Falou que Maria tem familiares que moram próximos a comunidade dela, mas eles não estão tão disponíveis para recebe-la, pela situação de vulnerabilidade e também porque Maria, desde que saiu da casa dos pais adota uma rotina muito de ir-e-vir nas ruas. Ela anda demais no bairro e a família já há tempos tinha uma rotina de pessoas muito caseiras, até pela religião dos familiares que são evangélicos.

No final ela falou se não sabe o que pode ser feito nesse estudo para ajudar a usuária. Mas esse é o caso mais difícil em muitos pontos de vista.

Falei que não existe uma resposta certa sobre estudo de rede. Eu vou tentar seguir juntando pontos de vistas diversos para tentar produzir reflexões e apostar em interferências para redes vivas. O que é possível ser construído para que Maria prossiga na vida mesmo diante de tantas mortes violentas? Será mesmo que a situação dela é tão difícil que necessite de uma ação conjunta de vários dispositivos de diversas redes para além das redes de saúde? São questões que aos poucos vou tentando construir respostas junto com eles e outros profissionais de saúde.

Foram então agendados outros momentos de conversa com diversos profissionais do CAPS e da Unidade de Saúde da Família que participaram do cuidado a Maria. Para não comprometer a identificação das pessoas vou a seguir apresentar um texto integrando os vários pontos de vistas dos diferentes profissionais, como fiz no capítulo anterior, narrado em terceira pessoa do plural. Importante salientar que diferentemente do processo com Consultório NA Rua e Consultório DE Rua, em que 
houve mistura ativa de algumas pessoas como pesquisadores locais, optou-se por partir de um relato inicial compartilhado em reunião de equipe somando a relatos dos diferentes pontos de vistas acessados nessas conversas rumo à usuária-guia. Nesse caso a pesquisadora, com o apoio da profissional residente pesquisadora local RAC Recife, foi conversando com um e outro profissional até compor o texto.

Importante situar que várias vezes os profissionais falaram do prontuário como um instrumento a mais para eu qualificar o olhar em relação à Maria como usuária-guia. Mas eu resisti, queria ouvir, ver, sentir Maria transbordando nesse encontro que nem sabia se aria acontecer ou não. Como um pacto levado a risca não fiz nenhuma gravação em áudio, seguindo o acordo debatido na reunião de equipe.

Havia a preocupação se a aposta rumo a essa usuária iria acontecer já que ela se encontrava numa situação tão delicada de segurança. Eu não sabia tanto quanto eles onde essa processo ia levar, mas eu fui adiante, e a cada conversa ia me encantando por Maria tentando interferir de algum modo para explorar essa tal rede viva, catando entre um olhar e outro algum resto de vida. Falava com um e outro, depois de muito andar encontrei Maria por duas vezes. Diferentemente de Pedro, uma "pedra" ou "planta", Maria era aparece-esconde quando ela quer. Todos os profissionais disseram isso de Maria. E de tanto eu ir atrás vencendo meus próprios medos, de fantasia e de potenciais violências, eu fiquei ponto para ser vista por tanto querer ver Maria. Nos encontramos e tudo valeu a pena porque Maria inspira e eu mudei depois que me encontrei com ela que já me atravessava e me fazia seguir em frente.

Como se falou, Maria é uma mulher com uns quarenta e poucos anos. Casou jovem. Teve cinco filhos homens. Sua primeira crise foi quando teve seu terceiro filho. O quarto filho temporão nasceu quando ela já tinha uns 40 anos.

A primeira vez que a usuária chegou ao CAPS foi em 2009 sendo encaminha pelo hospital psiquiátrico ligado a Secretaria Estadual de Saúde de Pernambuco. Tentou-se construir um projeto terapêutico para a usuária, mas essa não conseguia adesão ao tratamento. Possivelmente a crise estava associada à vida conjugal por causa de suposta traição do marido. 
Possivelmente essa crise foi desencadeada por desavenças na vida do casal, por possíveis traições do marido que era uma pessoa um tanto "embrutecida". Supostamente Maria não suportava saber que seu esposo a traísse e acabava surtando, quebrando tudo na casa, tirando a roupa no meio da rua. $\mathrm{O}$ esposo dela trabalhava com carga e descarga. Esse relacionamento também não era bem visto pela família de Maria desde o início. Mas Maria também não era de estar na vida da Igreja, gostava de circular pelo bairro e gostava muito de cuidar da casa.

Fala-se muito da disposição de Maria em manter a casa arrumada. Mesmo em seus momentos de alteração, sempre gostava de se dedicar à arrumação de sua casa, que foi construída por ela e pelo marido.

Nesse primeiro momento de tratamento de Maria no CAPS, a técnica de referencia dela naquele momento chegou também a construir projeto singular para Maria em parceria com profissional do NASF da área. Contudo, pela dificuldade de adesão de Maria não conseguiram ir adiante no tratamento no CAPS. acabou sendo internada em uma clínica psiquiátrica e ficou muito debilitada nesse espaço. Também não costumava receber visita do marido ou dos filhos. Depois de seis meses recebeu alta e retornou para sua casa.

O tempo foi se passando e Maria não tinha boa adesão ao tratamento. Não conseguia tomar direito a medicação e não participava de atividades terapêuticas. Era essa dificuldade no CAPS e na USF de sua área.

Em 2011 Maria engravidou e não conseguiu fazer o pré-natal de forma regular na USF, mesmo com os estímulos dessa equipe. Acabou parindo em casa um menino. Um dos filhos de Maria correu para chamar a agente comunitária de saúde e também o médico foi avisado. Ao chegarem na casa de Maria a situação estava muito delicada porque se temia pela saúde da criança por conta do transtorno de Maria. A Agente Comunitária de Saúde expressou que foi um dos momentos mais tristes que ela presenciou na vida, uma mãe sofrendo muito pelo transtorno e não pudendo ter o momento da maternidade, de segurar uma vida que se pariu. Mas eles precisavam fazer algo. 
No processo do parto foi acionado o SAMNU que prestou o atendimento imediato pós-parto. $\mathrm{O}$ bebê foi encaminhado para maternidade da região. E o médico do PSF foi para o CAPS pedir ajuda da equipe para juntos fazerem uma intervenção de emergência. Ele estava muito preocupado porque não conseguia fazer exames clínicos e Maria poderia ter alguma complicação do pos-parto. "Lembro como se fosse hoje, Dr. Fulano chegando de taxi bem cedo no CAPS pedindo ajuda para cuidar de" Maria. "Não é todo médico que se abala desse jeito pelas pessoas de seu território", falou um dos profissionais de saúde. Disse ainda: "Ele é diferente. É médico de família. Tem perfil para o trabalho que não é fácil. Lembro de uma vez que fomos fazer uma visita na comunidade ${ }^{10}$ e eu me lembro dele correndo subindo as escadarias, suado, vindo ao nosso encontro. Eu disse Por que você não esperou que a gente ia busca-lo? E ele disse: É mais prático eu subir as escadas. Já estou acostumado". Diante disso falou: "Esse veste mesmo a camisa da Saúde da Família”.

Sobre esse dia o médico do PSF disse que foi muito impactante para ele lidar com aquela situação de um parto em casa e Maria numa situação de extremo sofrimento. Falou que o circuito do atendimento para esse parto foi assim. Foi acionada a maternidade do Distrito, que acionou unidade móvel do SAMU, que fica na própria maternidade. Depois o Distrito acionou o a USF. O médico foi para o CAPS. de lá saíram ele, dois técnicos, um residente de saúde mental. Foi então acionado o SAMU novamente e a Policia Militar, para dar retaguarda. Conseguiram então medicar Maria, que foi levada para a maternidade, a mesma que estava seu filho.

Os profissionais do CAPS e PSF falaram que foi feito um intenso trabalho para trabalhar essa relação da criança com a mãe e família de Maria. Mesmo a criança na maternidade $m$ situação estável, os familiares foram sequer visita-lo como fazem geralmente boa parte das pessoas quando chega um membro na família. Também a família de Maria também não esteve presente nesse processo de construção de vinculo da família e Maria com o bebê. Mesmo assim houve um trabalho de meses dos profissionais do CAPS e USF para se entender ou construir vínculos familiares. Mas o bebê acabou indo para adoção. Um dado salta aos olhos: o nome dado ao bebê era o mesmo do médico do PSF.

\footnotetext{
${ }^{10}$ Os profissionais costumavam fazer visitas domiciliares e também havia transporte para levar e trazer alguns usuários com dificuldade em acessar o CAPS. Mas há uns meses que essas visitas diminuíram por dificuldades com transporte. E também por conta da violência dos bairros.
} 
Esse processo de entrega da criança para a adoção foi extensamente elaborado pela equipe do CAPS na supervisão clínica no serviço. Até pensam em escrever um "caso clínico" detalhando as estratégias e ferramentas que foram construídas para a atenção à saúde de Maria. O CAPS também abriu várias possibilidades para a participação da família para participarem do tratamento de Maria, mas vários dos profissionais apontaram para a rudeza da família, cujos membros chegavam até a bater em Maria. Mas essa ainda era a mãe e voltou a seus afazeres do lar.

Os profissionais do CAPS e USF falaram que algo mudou em Maria depois desse processo de cuidado relacionada a elaboração para a entrega da criança para a adoção. Maria, com o tempo já cuidava de sua medicação e até ajudava uma usuária do CAPS que era sua vizinha. O cuidado de Maria passou a ser na ESF pois Dr Beltrano é "médico de cabeça de cabeça" (psiquiatra do CAPS), mas "eu já posso ficar acompanhada pelo médico do corpo" (médico do PSF). O médico da USF acompanhava o uso da medicação e se ela necessitasse de um especialista poderia contar com dispensação de medicação por psiquiatra da clínica de especialidades ( o termo é esse mesmo porque praticamente havia uma transcrição da medicação e não um acompanhamento sistemático). Mas se necessitasse, podia ir para o CAPS conversar com o médico para saber da medicação.

Sobre esse manejo da medicação pela própria Maria, o médico explicou que costuma trabalhar essas questões de medicamentos em grupo com os pacientes porque assim eles mesmos podem falar sobre a forma como administram. $\mathrm{O}$ profissional pode até falar sobre medicação, mas é no debate envolvendo profissional e os vários usuários do serviço que ajuda a compreender esse tipo de autocuidado. Claro que havia idas e vindas desse processo que não é estático. Muitas vezes mudava a cor da medicação ou o formato de apresentação e Maria se recusava a tomar o remédio. Assim foi a situação em que vi Maria pela primeira vez, na USF. Foi várias vezes enquanto eu estava conversando com a ACS, falar que precisava falar com o medico sobre a medicação.

Mas voltando ao processo de Maria, tudo parecia estar se organizando quando no ano de 2015 ela perdeu o marido que teve uma parada cardíaca. Mesmo tendo a USF, medico e ACS falava que ele nunca ia se cuidar. Nesse período houve o assassinato de seus três filhos nas brigas por causa da violência nesse território. $\mathrm{O}$ único filho vivo, o mais velho que tentava buscar outra via, acabou vingando a morte dos irmãos e 
assassinou um irmão de um dos chefes do "movimento". Estava foragido. A violência foi tamanha que a casa de Maria foi destruída e incendiada e se temia que ela voltasse a circular na comunidade. Mas para onde ela iria? Ela que cuidava da casa e da família havia perdido tudo?

Quando fui em busca de Maria, meu coração ficava apertado, eu que também sou mãe, ficava pensando no terrível sofrimento que ela estava sentindo. Eu enlouqueceria. E tantas pessoas com quem conversei, que participaram de alguma forma do cuidado com Maria também assim falaram. Mas talvez ela em sei processo de ir-evim nos surtos foi aprendendo a prosseguir e construir outros caminhos. Alguns falaram que Maria tinha uma personalidade "muito forte", "só era o que ela queria", "ela batia de frente com todo mundo", mas esse tipo de enfrentamento também é reafirmação de si no mundo. Um dos técnicos do CAPS falou que Maria sempre desafiava os técnicos num constante embate e provocação, mas os trabalhadores aprenderam a lidar com esse modo de provocar. Era possível construir outro modo de relação (uma reparação do objeto de amor talvez apontasse a psicanálise) sem se pautar na destruição, no devastador.

Nas minhas idas-e-vindas em busca de Maria também fiquei com receio da violência. Logo nas primeiras semanas foi avisada que deveria "deixar a poeira baixar" para chegar ata comunidade, aviso que o médico da USF deu para a equipe do CAPS. Esperei e fui ao encontro com o médico que me falou seu processo de cuidado para com Maria e que me confirmou que ela havia voltado ao território. Estava morando com uma amiga dela que era usuária do CAPS. ele estava preocupado porque lá também tem vulnerabilidade. Mas ela está indo bem até então.

A USF dessa equipe de referencia de Maria, na época estava em reforma. Há quase um ano a unidade estava fechada por conta de obras. A equipe ficava atendendo na casa de pessoas do bairro e também uma Igreja havia cedido seu salão para que pudessem ser realizados os atendimentos.

A equipe também recebe profissionais residentes do Programa de Residência em Saúde da Família. 
Em um dos momentos, do campo da pesquisa, estive presente nos atendimentos realizados nessa Igreja. Depois da conversa com a ACS fiquei lá sentada no salão vendo o movimento. As pessoas sentadas esperando para serem atendidas. No mesmo ambiente de espera havia uma mesa, cadeiras, medico e residentes em um outro canto realizando os atendimentos. Atrás deles um biombo e uma maca por traz da mesa de atendimento. Em outro canto estavam os demais componentes da equipe fazendo outras atividades como marcação de consulta, orientação sobre dispensação de medicação, cartão SUS etc.

Foi então que a vi. Claro que tenho um olho para captar quem tem alguma coisa de estranho. Mas já soube que era ela quando a vi. Uma mulher esguia, de passos apressados, falando de forma afetada solicitando uma explicação sobre a medicação. Os residentes falaram com ela, estando ao lado do médico. Uma das residentes era farmacêutica e explicou o esquema medicamentoso. Passou alguns minutos explicando e parece que Maria se deu por satisfeita com relação à medicação. Pelo menos naquele momento estava satisfeita. Falou então com o pessoal da equipe e com a ACS. Perguntou sobre um filho de uma delas. Que falou que ele estava bem. Dai ela falou de seu filho pequeno que teria tal idade. Era ela. Depois saiu da mesma maneira rápida com que entrou. Olhei para a ACS eu ela disse baixinho "É ela" e eu disse "Eu sei".

Depois d muita peleja conseguimos marcar um encontro na casa da ACS para que eu pudesse conversar com Maria. Nesse dia, acabei vivenciando meu medo. Tenho muito medo de moto. Mas em comunidade de morros são comuns os deslocamento em mototaxi. E lá fui eu. O pessoal na unidade em reforma chamou um rapaz com mototaxi que mora no entorno e lá fui eu subindo o morro. Mas valia a pena viver, transpor esse medo. Maria que aparece-desaparece nos serviços, nas relações de cuidado merecia esse me traspor de medo.

Chegando na casa da ACS lá estava Maria, sentada ao lado de sua colega, com quem estava morando naquele momento. Expliquei a pesquisa para ela e ela aceitou conversar. Avisou que não podia ficar muito tempo porque teria que levar a amiga para a urgência. O médico que também estava lá indicou que ela fosse buscar uma urgência pois ele não tinha como realizar o atendimento uma vez que a unidade estava em reforma. 
Ela me falou que havia perdido os filhos pela violência. "Queimaram atpe minha casa. Você quer ir ver a minha casa? Queimaram tudo." Mas estou seguindo. Nesse momento a amiga falou: "Se fosse eu, teria enlouquecido. Mas ela é forte e está conseguindo". Maria falou que tinha muita fé em Deus e nos estudos dos homens. Que esta tomando os remédios e se cuidando.

Falamos também de um netinho que ela ganhou recentemente. Filho de um dos filhos assassinados. Ela falou que ele é lindo. Convidou também a ACS e o médico para conheceram esse neto. Falou que vai ser bom estar perto para vez por outra estar com ele. Não pensa em morar lá com eles ou com a sua mãe e irmãos. Esta bem onde está. Cuida de sua colega, arruma a casa, ajuda com a medicação da amiga. Falou que tem que seguir com a vida. Gostei de tê-la conhecido. Foi um acontecimento ela querer estar nessa conversa que ocorreu no terraço da casa da ACS. Nos despedimos e ela se foi cuidar da amiga.

Lembrei de uma reflexão que o médico trouxe: a autonomia é o que há de bom e ruim na vida de Maria. Mesmo que as varias pessoas que busquem construir alternativas de caminhos para Maria, como a técnica do CAPS que organizou todo um processo de pactuação para que Maria fosse para um abrigo, mesmo assim Maria voltou para seu território. Esse território que traz tantas perdas pela violência, seja da "brutalidade" daqueles que compuseram sua família construída ou violência da criminalidade, ainda assim ela volta. Agora não porque precisa dessa família, mas porque ela ali tem um lugar para exercer o cuidado, nem que seja cuidar de uma amiga que também tem transtorno psiquiátrico.

Falei para o médico que era muito forte também o vínculo dela com a equipe, com ele e com a ACS. Ele deu o nome do médico ao seu ultimo filho, esse dado é muito significativo. Por mais que ela "dê umas surtadas", falando que roubaram o filho dela ou venderam, ela ainda continua voltando, quase que todos os dias para a USF. Talvez a unidade seja mesmo um elo familiar que ela também construa os afetos.

Outro ponto importante a ser considerado foi uma informação que a ACS trouxe na nossa conversa. Ela me disse que a avós do rapaz que foi assassinado pelo filho de Maria clamou para que o neto não vingasse o irmão. Maria já perdera tudo, era 
muito sofrimento para uma mãe perder todos os filhos. Ela já sofreu muito e era hora de cessar tantas mortes.

Maria foi o lusco-fusco de quem se move em um território dos afetos, construído pela afronta atravessada por afeto e cuidado. 


\section{DESENHO TECNOASSISTENCIAL: PROVOCAÇÕES E APOSTAS RUMO A REDES VIVAS}

Os escritos a seguir têm como propósito provocar a articulação entre pessoas e serviços de saúde de modo a potencializar o debate sobre redes de saúde. Parte de releitura de diversos autores sobre concepção de "modelos de atenção à saúde" a partir da perspectiva micropolítica. Nesse sentido, espera-se que o debate sobre diferentes concepções de organização dos serviços de saúde, atravesse e provoque o cotidiano das pessoas e serviços de saúde para a produção de redes vivas em saúde.

\section{De Modelo a Desenho Tecnoassistencial}

A palavra Modelo é um substantivo masculino que se refere a um objeto que se destina a ser reproduzido por imitação; na arquitetura tem relação com maquete; nas rates plásticas o modelo se refere a molde, que venha a permitir a reprodução de algum objeto, está ligado à ideia de protótipo.

Por outro lado, a palavra desenho, por sua vez, é um substantivo masculino que diz respeito a uma representação gráfica, por meio de linhas, cores e sombras, de objetos, ideias e sensações. Na arte e técnica, desenho representa visualmente a forma dos elementos, servindo-se de linhas ou traços, efeitos de luz, cores e sombras. Também diz respeito a plano ou projeto de objetos com finalidade técnica, industrial, científica, ornamental, arquitetônica; esboço, planta, risco, traçado. Também se relaciona à Idealização de um propósito ou objetivo qualquer; desígnio, intenção, plano.

Assim, nesse primeiro plano de análise, de um lado modelo parte de uma ideia de molde e que pode ser reproduzido em diferentes situações, em contrapartida a palavra desenho, mesmo também relacionada ao grafismo, se caracteriza pela representação por meio de linhas, cores e sombras. Modelo está para molde e reprodução, enquanto desenho está para um propósito relacionado a uma ideia, intenção, plano. 
No campo da Saúde Coletiva existem vários estudos que abordam e concepção de modelos de saúde. Paim (2008) pondera que um sistema de saúde é formado por componentes e funções principais como infra-estrutura, organização, gestão, financiamento e prestação de atenção, estando o modelo de atenção ou modelo assistencial referindo-se ao cuidado, à assistência, à intervenção, às ações ou às práticas de saúde.

O referido autor vai além quando pondera que a partir de 1980 houve na área de saúde grande produção de textos técnicos, documentos oficiais e publicações científicas abordando a temática de modelões de atenção em saúde, mas que não traziam preocupação com o que significavam.

De uma forma ampla, o referido autor quando busca abrir o debate para o termo "modelo" aponta para a armadilha que o mesmo provoca pois a palavra insinua enquadramento, normatização ou padronização, fazendo-se necessário alertar ou, se possível, evitar.

No campo da ciência, modelo muitas vezes se confunde com "paradigma", que também é polissêmico, ou seja, possui várias conotações, mas que se refere a uma representação simplificada da realidade onde se retêm e se destacam seus traços fundamentais. Modelo então pode ser um desenho (modelo pictórico), um conjunto articulado de conceitos (modelo teórico), ou uma fórmula (modelo matemático)

Justamente essa representação esquemática e simplificada de um sistema de saúde, no que tange à prestação da atenção, pode ser entendida como modelo de atenção ou modelo assistencial. Não como algo exemplar, uma norma ou padrão, que todos devem seguir, mas uma identificação de seus traços principais, seus fundamentos, suas lógicas, enfim, sua razão de ser ou racionalidades que lhe informam (548)

O referido autor também refere que "modelo de atenção à saúde pode ser definido como combinações tecnológicas estruturadas para a resolução de problemas e para o atendimento de necessidades de saúde, individuais e coletivas (554) 
O modo com as sociedades se relacionam com os processos de saúde-doençaintervenção produz formas de organização dos serviços de saúde. Diz respeito a escolhas éticas e políticas. Nesse sentido, Merhy (2000) problematiza que modelo de atenção à saúde ${ }^{11}$

faz referencia não a programas, mas ao modo de se construir a gestão de processos políticos, organizacionais e de trabalho que estejam comprometidos com a produção dos atos de cuidar do indivíduo, do coletivo, do social, dos meios, das coisas e dos lugares. E isto sempre será uma tarefa tecnológica comprometida com necessidades enquanto valores de uso, enquanto utilidades para indivíduos e grupos.

No Brasil, lutas políticas de diversos segmentos da sociedade, que agregaram movimentos de trabalhadores da saúde, docentes e pesquisadores de universidades, e movimentos sociais, levaram à construção do Sistema Único de Saúde (SUS), instituído na Constituição da República Federativa do Brasil de 1988. A implementação do SUS foi ocorrendo na década de 1990 e fundamentou vários atores na produção de diversos arranjos de serviços de saúde. Nesse sentido, vale a pena destacar princípios norteadores do SUS:

Universalidade refere que todo e qualquer cidadão têm direito à saúde e que essa garantia é dever do Estado; Equidade: mesmo que todos tenham direito aos serviços de saúde, deve-se considerar que as pessoas não são iguais e têm necessidades diferentes. Equidade é a garantia a todas as pessoas, em igualdade de condições, ao acesso às ações e serviços dos diferentes níveis de complexidade do sistema. Integralidade aponta para ações de promoção, proteção e reabilitação da saúde devem estar articuladas, de modo que os serviços de saúde devem reconhecer que cada pessoa é única ao mesmo tempo em que é integrante de uma comunidade, sendo esses elementos para a construção das ações e serviços de saúde. Esses são "princípios finalísticos” que dizem respeito à natureza do sistema que se pretende conformar. Há ainda "princípios estratégicos", que dizem respeito à diretrizes políticas, organizativas e operacionais, apontando "como"

\footnotetext{
${ }^{11}$ Modelo de Atenção à Saúde como Contrato Social. Texto apresentado na XI Conferência Nacional de Saúde.
} 
deve vir a ser construído o "sistema" que se quer conformar, institucionalizar. Como "Princípios estratégicos" aponta-se para Regionalização e hierarquização, que indicam que a rede de serviços deve ser organizada de forma hierarquizada e regionalizada, de modo a permitir maior ou mais adequado conhecimento sobre a situação de saúde da população de determinado território, favorecendo ações de dos serviços de saúde.

Esses princípios do SUS devem impulsionar o agir no cotidiano da prestação da assistência e cuidado em saúde. Mas o cotidiano dos serviços, na relação entre as pessoas e instituições, não é suficiente conhecer tais princípios, é preciso relacioná-los com atores que fabricam cotidianamente a assistência e o cuidado em saúde. E no cotidiano das pessoas nos serviços de saúde se vivenciam as disputas por diferentes e divergentes processos de saúde-doença-intervenção.

Mas o modo como são construídos os serviços e a relação entre eles para a construção de processos de saúde-doença-intervenção são diferentes a depender pelo cenário e articulação entre atores sociais. Sendo a instituicionalização do SUS atravessada por elementos instituídos e instituintes em disputa, optou-se nesse texto por levantar o debate sobre a prestação dos serviços de saúde na rede de saúde pela perspectiva de desenho tecnoassistencial. Esse desenho, por outro lado pode ser compreendido nessa dimensão de imagem-objetivo a ser seguido, mas ao mesmo tempo deve contemplar os atravessamentos de forças que ampliam ou reduz a potência de determinado desenho.

Assim, a noção de desenho problematiza que um "modelo" se refere a uma configuração provisória de práticas, que representa sempre um embate entre conservação e mudança (Brasil, 2005). Provoca um movimento de liberdade para elaborar novas combinações ou arranjos entre diferentes recursos disponíveis e sua relação com o uso social de cada arranjo tecnológico e assistencial.

Como um primeiro plano para a construção da dinâmica de desenhos tecnoassistenciais, é importante situar que as forças que afetam a produção da gestão do cuidado é atravessadas por planos de horizontalidade, verticalidade e transversalidade. Horizontalidade, na psicologia social de Pichon Rivière designa a dimensão atual do grupo, ou seja, diz respeito a um conjunto de elementos que coexistem e operam, configurando o aqui e agora. Diz respeito aos processos informais tão presentes em 
fenômenos de grupo como "rumores”, “fofocas”, "rádio corredor”, vínculos sexuais. Em outro plano, há a verticalidade, que para Pichon Rivière, designa a dimensão históricopessoal, que cada integrante do grupo traz como disposição para compor os fenômenos do campo grupal. Em termos gerais, diz respeito à dimensão formal das organizações: cargos, hierarquia, funções. Já a transversalidade se refere ao movimento de interpretação, entrelaçamento, está associada à imagem do rizoma, que é imanente à rede social. A transversalidade é veinculada pelas linhas de fuga do desejo e da produção do devir que não se reduz a uma ordem ou hierarquia da verticalidade e nem à ordem informal da horizontalidade nas organizações. Nessa potência da produção do novo, ativa produções insólitas entre elementos incompatíveis, originando efeitos à distancia sem transmissões detectáveis, a partir de conexões locais. Extrapola o limite dos códigos formais e oficiais, deflagrando efeitos transversais inventivos e libertários.

A disputa de/entre forças que se atravessam a vida em micropolítica também está relacionada aos conceitos de molar e molecular. $\mathrm{O}$ termo molar se refere à ordem de organização do real que caracteriza a superfície de registro e controle. O plano molar traz o campo da regularidade, estabilidade, conservação, reprodução, do mundo "macro". É o lugar dos códigos, sobrecódigos e axiomáticos, das formas sujeitos e objetos definidos, dos estabelecidos e instituídos. Já o molecular caracterizam-se pela superfície de produção desejante, com conexões que fazem circular fluxos (devires) interrompidos por cortes, provocando desterritorialização das entidades molares para um movimento em linhas de fuga. Molecular corresponde parcialmente ao instituinte.

Não se está aqui fazendo uma correspondência conceitual entre instituídosinstituinte-institucionalização e molar-molecular-linhas/de-fuga, mas para destacar esses conceitos como potentes para pensar os cenários de disputas que atravessam as pessoas e serviços de saúde, numa perspectiva micropolitica.

Esses conceitos relacionados à disputa em planos e a forças trazem uma estratégia argumentativa de escapar da perspectiva de cópia. No institucionalismo, cópias estão relacionadas ao pensamento platônico, de ideias puras ou modelos. Nesse sentido, quando se aposta aqui em desenho é uma tentativa de apontar para desenhos tecnoassistenciais em disputa no cotidiano do agir em saúde. Desenho aqui é um termo que refere linhas e tensões e se relaciona a um agir cartógrafo, que se deixa afetar pelas provocações diante dos encontros e desencontros rumo à vida, com disputa entre 
instituídos-instituinte-institucionalização, entre molar-molecular-linhas/de-fuga. Assim, o modo como os serviços são articulados (ou não) para atender a população são atravessados por essas forças, sendo que essas também seguem uma determinada lógica de operar no agir cotidiano das pessoas nos serviços de saúde.

\section{Desenhos tecnoassistenciais: perspectivas em tensionamento}

Nesse estudo, parte-se da reflexão que há atravessamentos entre diferentes planos de forças que tencionam a disputa política no cotidiano das pessoas nos serviços de saúde. Por exemplo, não é construindo unidade de saúde da família, realizando seleção de profissionais comprometidos com a saúde pública, promovendo qualificação e cursos dos profissionais, que se produz um cuidado integral seguindo os preceitos da Estratégia de Saúde da Família. Pode-se nesse espaço ocorrer uma atenção centrada no poder biomédico, em que o usuário nem sequer é considerado. $\mathrm{O}$ usuário também pode construir seu agir atravessado por esse poder biomédico. Dessa forma, há atravessamentos e disputas no campo micropolítico que é um cenário de disputas de biopoder. O usuário também exerce seu poder quando ele modifica seu trajeto na rede de saúde ao entrar por um determinado serviço de saúde.

Considerando-se conceitos de disputa entre instituídos-instituinteinstitucionalização, entre molar-molecular-linhas/de-fuga, que ocorrem na disputa micropolítica da gestão do cuidado nos serviços de saúde, optou-se por reorganizar os serviços em desenhos a partir de perspectivas.

Perspectiva é um substantivo feminino. No desenho ou pintura se refere à arte ou técnica de representar tridimensionalmente, criando ilusão de profundidade e proporção das figuras, de modo que estas, no espaço do ponto de vista do observador, pareçam bem menores à proporção que cresce a distância. Trata-se do método que possibilita ilusão de um espaço tridimensional, pelo qual retas paralelas projetadas longe do primeiro plano são desenhadas como linhas diagonais que convergem e se encontram em determinado ponto. Também significa visão que se estende ao longe, até onde os olhos podem alcançar; prospectiva. Refere também a ponto de vista; modo particular com que cada pessoa, influenciada por seu tipo de personalidade e por suas 
experiências, vê o mundo. Quer dizer também aparência, visão ou aspecto sob o qual algo se representa; sentimento de esperança e expectativa.

Por outro lado, perspectiva pode ser construída enquanto processo de produzir visibilidades sobre determinado objeto, enquanto movimento de produção de conhecimento na e para a vida em acontecimento. Assim, para Moebus (2014, p. 130) perspectivismo não estaria respaldado numa posição relativista, em que tudo vai dar no mesmo ou nada vale a pena, o que poderia cair no niilismo. Ao contrário, perspectivismo busca combater ideia de verdade absoluta sem cair no niilismo, "abrindo passagem para visibilidades acerca do agir em saúde, e as tomadas de decisões que estas visibilidades nos exigem, como compromisso ético-estético-político".

Considerando outras possibilidades de produção de visibilibilidades em relação ao objeto aqui estudado, ao revisitar estudos sobre "Modelos de Atenção em Saúde", optou-se por renomear alguns "modelos" para "Perspectiva" tentando agregar para cada uma delas elementos que a caracterizassem enquanto linhas de força que tencionam o arranjo de determinado desenho tecnoassistencial. Assim, mesmo que uma determinada marca de projeto de gestão adote um "Modelo" entende-se que há os atravessamentos de diferentes forças que (des)potencializam esse referencial.

Além do mais, também se entende que desenho tecnoassistencial também oriente a "imagem-objetivo" ${ }^{12 ", ~ a ~ s e g u i r, ~ b u s c a n d o ~ m a p e a r ~ p r o c e s s o s ~ a s s i s t e n c i a i s ~ n e s s e s ~}$ serviços, buscando compreender o comprometimento de determinado desenho com a atenção à saúde de acordo com os princípios e diretrizes do SUS.

Assim, optou-se por renomear alguns "modelos de atenção à saúde" e trazer outros elementos para a reflexão sobre os arranjos de prestação de assistência em saúde de modo a atingir os propósitos desse estudo.

\footnotetext{
12 "Enuncia-se uma imagem-objetivo com o propósito principal de distinguir o que se almeja construir, do que existe. Toda imagem-objetivo tenta indicar a direção que queremos imprimir à transformação da realidade. De certo modo, uma imagem objetivo (pelo menos as imagens-objetivo construídas nas lutas por transformações sociais) parte de um pensamento crítico, um pensamento que se recusa a reduzir a realidade ao que "existe", que se indigna com algumas características do que existe e almeja superá-las. Os enunciados de uma imagem-objetivo sintetizam nosso movimento. Ao enunciar aquilo que, segundo nossa aspiração, existirá, a imagem-objetivo também fala, embora sinteticamente, daquilo que criticamos no que existe, e que nos levou a sonhar com uma outra realidade". (Mattos, ???, 45)
} 
Centrado no poder biomédico hegemônico, centrado na clínica que atende demanda espontânea e fundamentado nos procedimentos especializados. É centrado na doença e não no doente; seu principal agente é o médico principalmente no especialista; o trabalho do médico é complementado por outros profissionais "paramédicos"; a formação médica com formação segmentada por ciclos básicos e profissional, sendo este último centrado na formação nos hospitais.

\section{Perspectiva da atenção gerenciada}

São caracterizados pelas cooperativas médicas, medicina de grupo, operadoras de planos de saúde em autogestão ou seguro-saúde, caracterizando um modo de produção do cuidado centrado não apenas na relação médico-paciente, mas atravessada pelos interesses de diferentes atores sociais: financiadores, provedores, consumidores, captadores de recursos e administradores. Também relaciona o capital financeiro no atravessamento da relação entre cuidador e usuário do serviço.

\section{Perspectivas de campanhas sanitárias e programas especiais}

Perspectiva de influencia das disciplinas biológicas/biomédicas e epidemiológica. Concentra-se em abordar determinados riscos ou agravos de saúde que afetam determinados grupos populacionais. Tem origem influencia a intervenção sanitária, centrada numa administração vertical. Nota-se a burocratização dos processos de saúde-doença-intervenção. São exemplos os programas de DST/Aids, diabetes, saúde mental etc. Desconsidera-se que uma mulher pode estar no processo de gestação, mas também pode ter hipertensão, pode estar deprimida por um acidente de trabalho e outras contingências que a vida produz.

\section{Perspectiva da Vigilância à Saúde}

A proposta da Vigilância à Saúde foi construída a partir de experiências desenvolvidas nos Distritos Sanitários ou Sistemas Locais de Saúde (SILOS) no final 
dos anos 1980 e início dos anos 1990, por iniciativa de Secretarias Estaduais e Municipais de Saúde, com apoio da Organização Panamericana de Saúde (OPAS) e Cooperação Italiana em Saúde, proposta operacionalizada principalmente nos estados do Ceará (CE) e Bahia (BA) (Andrade et al, 2009; Teixeira, 2006).

As fundamentações do DS (SILOS) estava apoiada na regionalização dos serviços de saúde na Inglaterra nos anos de 1920, por Dawson, matriz de macro organização do National Health Service (NHS); bem como na experiência de organização de serviços de saúde na Itália. Nessa época da implantação dessa experimentação de organização de serviços de saúde, no Brasil haviam o Sistema Unificado e Descentralizado de Saúde (SUDS).

A Vigilância à Saúde, segundo Teixeira (2006), além de considerar o esquema abstrato que organiza os diversos níveis de prevenção (diagrama de Leavell e Clarck), vai ampliando a análise do processo saúde-doença ao considerar as práticas de saúde tal como se apresentam ou podem vir a apresentar no cenário brasileiro. (Teixeira, 2006).

Paim (2008) pondera que a Vigilância em Saúde busca articulação de conhecimentos biomédicos e epidemiológicos articulados com outros elementos como jurídicos e determinantes sociais da doença. Também é importante integrar as vigilâncias (epidemiológica, sanitária e ambiental) com a assistência médica e políticas sociais.

Uma das críticas de Teixeira (2006) a essa concepção é que por ter caráter abrangente acaba não avançando na organização do processo de trabalho e saúde, muito embora tenha havido diálogo com elementos levantados pelas “ações programáticas".

\section{Perspectiva "Em Defesa da Vida”}

O Movimento em "Em Defesa da Vida" foi construído em Campinas/SP no final da década de 1980, impulsionado por um grupo de profissionais que atuavam no Centro Brasileiro de Estudos de Saúde (CEBES) e que criaram o Laboratório de Planejamento e Administração em Saúde (LAPA) na Unicamp (Andrade et all, 2009; Campos, 1994, 1996; Merhy, 1994; 1997; Cecílio, 1994; Teixeira, 2006). 
Na época da IX Conferência Nacional de Saúde, em 1992, o LAPA publicou sua proposta de "Modelo Tecnoassistencial" que indicava que "Em Defesa da Vida" estava fundamentado nos seguintes princípios: gestão democrática; saúde como direito de cidadania; serviço público de saúde voltado para a defesa da vida individual e coletiva (Andrade et all, 2009, )

Teixeira (2006) faz uma síntese sobre "Em Defesa da Vida" que merece destaque a seguir. A autora aponta que esses autores têm como objeto central

o processo de trabalho em saúde e seu propósito, intelectual e político, indica o desejo de criar metodologias e instrumentos de gestão e organização do trabalho coletivo que desencadeie uma revolução molecular no âmbito das instituições em saúde e resulte no estabelecimento de novas relações entre gestores, trabalhadores e usuários, mediadas pela busca da autonomia e reconstrução de subjetividades. Com isso, estamos diante de uma perspectiva de transformação radical das pessoas e das práticas, que busca criar processos instituintes, subvertendo modelos instituídos, entre os quais, não só os modelos de organização social da prática médica e sanitária hegemônica, senão também propostas alternativas fundadas nas ideias de descentralização, regionalização e hierarquização de unidades de prestação de serviços, tornadas supérfluas pelo estabelecimento de processos que privilegiam acolhimento, os vínculos, o contrato e autonomia dos sujeitos - trabalhadores e usuários - na organização do cuidado progressivo à saúde (31-32).

A referida autora critica tal perspectiva indicando que não apontam propostas em relação ao desenho macroorganizacional do sistema, "coisa alias, que extrapola o universo teórico-conceitual e a perspectiva político-filosófica dos autores" (33).

\section{Perspectiva Ação Programática em Saúde}

Várias propostas do grupo de docentes e pesquisadores atuantes no Centro de Saúde Escola Samuel Pessoa, ligado ao Departamento de Medicina Preventiva da USP (DMP/USP) são identificadas por vários autores como "ações programáticas em saúde". Nessa perspectiva, parte-se da reflexão sobre a programação enquanto metodologia que pode ser referencia para a reorganização do processo de trabalho em saúde. Assim, partindo de um viés marxismo estruturalista incorporando enfoque epidemiológico em 
perspectiva crítica, chegou a problematizar a dimensão ética do cuidado à saúde a partir de concepções filosóficas.

Os autores dessa perspectiva defendem a delimitação dos objetos de intervenção nos serviços omo sendo "necessidades sociais de saúde" que seriam definidas em função de critérios demográficos, sócio-econômicos e culturais. Nesse sentido seria possível organizar as ações e serviços para programar ações voltadas para as necessidades de grupos que utilizam os serviços de saúde.

Andrade et al (2009) resume as principais características tecnológicas de organização do processo de trabalho: (1) Atividades eventuais de acordo com a demanda espontânea de que procurasse o serviço ou atividade de rotina para demanda organizada; (2) Programas definidos por ciclos de vida, por doenças especiais ou por importância sanitária; (3) Definição das finalidades e objetivos gerais considerando categorias coletivas; (4) Hierarquização interna das atividades; (5) Articulação das atividades por equipes multiprofissionais; (6) Padronização de fluxogramas de atividades e de condutas terapêuticas principais; (7) Sistemas de informação que subsidie avaliação na própria unidade; (8) Gerencia da unidade por médicos sanitaristas; (9) Regionalização e hierarquização das unidades.

Teixeira (2006) refere várias concepções em torno das "acoes programáticas" tencionam a programação em saúde no sentido de superar a o viés economicista da Programação Pactuada Integrada e a institucionalização da programação como espaço de construção coletiva do projeto de trabalho das equipes de saúde.

\section{Perspectiva Promoção Saúde e "Cidades Saudáveis"}

A concepção de Promoção da Saúde está relacionada a um conjunto de valores vida, saúde, solidariedade, eqüidade, democracia, cidadania, desenvolvimento sustentável, participação e parceria. Esses valores são correlacionados a uma combinação de estratégias que envolvem a ação do Estado (políticas públicas saudáveis), da comunidade (reforço da ação comunitária), de indivíduos (desenvolvimento de habilidades pessoais), do sistema de saúde (reorientação do sistema de saúde) e de parcerias interinstitucionais, trabalhando com a noção de 
responsabilização múltipla pelos problemase também pelas soluções para os mesmos. (Buss, 2003).

Conceitualmente vem construindo reflexões sobre conceito de saúde, problematização das diferenças e semelhanças entre estratégias de prevenção e promoção, estimulando epidemiólogos e cientistas sociais da Saúde Coletiva a aprofundarem estudo do conceito de risco e vulnerabilidade e suas implicações para a prática de saúde (Teixeira, 2006).

Essa perspectiva repercutiu na criação das "Cidades Saudáveis" que é uma concepção fomentada pela Organização Mundial da Saúde (OMS), que se refere a uma visão ampliada da gestão governamental, que inclui a promoção da cidadania e o envolvimento criativo de organizações comunitárias no planejamento e execução de ações intersetoriais. Tais ações estariam voltadas para a melhoria das condições de vida e saúde, sobretudo nos territórios onde a população está exposta a uma concentração de riscos vinculados às condições de vida, fatores econômicos ambientais e culturais.

A difusão e a incorporação da proposta de criação de "cidades saudáveis" têm sido incorporadas por várias administrações municipais nos últimos anos como Campinas, Curitiba, Fortaleza (Teixeira, 2003).

Um dificultador para essa perspectiva está necessidade de articulação entre diferentes setores governamentais.

\section{Perspectiva da Saúde da Família}

Na década de 1990 foram construídos dois programas: Programa de Agente Comentário de Saúde (PACS) e Programa de Saúde da Família (PSF), que eram programas especiais destinados ao atendimento de populações carentes. Com o passar do tempo o PSF foi sendo redefinido como uma estratégia de mudança do "modelo assistencial" uma vez que não estaria ligado a uma intervenção vertical paralela aos serviços de saúde, mas seria capaz de promover a integralidade do cuidado e promoveria a organização das atividades em um território definido. Além do mais, deveria ser substitutivo à rede básica tradicional, caracterizada por uma prática que 
requer alta capacidade tecnológica nos campos de conhecimento, desenvolvimento de habilidades e mudanças de atitudes.

A Estratégia de Saúde da Família é um desenho de atenção primária à saúde, que operacionalizam estratégias de prevenção, promoção, recuperação, reabilitação e cuidados paliativos construídas por equipes de saúde da família, responsáveis por coordenar o cuidado a pessoas em determinada área (área adscrita). Deve estar comprometida com a integralidade do cuidado a pessoas, famílias e comunidade de determinada localidade de determinado território, processado em mapa estático e dinâmico que trace a situação de saúde-doença-intervenção. Para tanto, conta-se com equipe multiprofissional, que se espera atuar de forma interdisciplinar, com médico, enfermeiro, técnico de enfermagem, em algumas conta-se com odontólogo e técnico em saúde bucal, e agente comunitário de saúde, sendo esse morador da comunidade onde a unidade está construída.

Paim (2008) destaca que a Saúde da Família é "uma combinação de tecnologias que depende, concretamente, de uma correlação de forças favoráveis à mudanças. Assim, em situações adversas, o PSF tende a se apresentar como um programa vertical como qualquer outro. No entanto, quando as forças das mudanças adquirem proeminência em relação às de conservação, o PSF pode se transformar em estratégia". (p. 567).

É tentando entender essa força instituintes que potencializam a saúde da família a extrapolar a perspectiva biomédica para uma produção de cuidado em saúde que é uma imagem-objetivo que movimenta vários atores sociais implicados com o SUS e com a integralidade da saúde. Mas como potencializar esse movimento instituinte?

Tensionamento entre perspectivas: atravessamento micropolitico no cotidiano das ações e serviços de saúde

No cotidiano dos serviços de saúde, há atravessamentos entre essas diferentes perspectivas porque a disputa, que se dá no campo macropolítico de espaços políticos como Congresso Nacional, Presidência da República, Ministérios, Governos Estaduais e Municipais ou mesmo nas centros universitários e revistas acadêmicas, também repercutem em determinadas formas de construção (ou destruição) de processos de 
cuidado ou assistência no campo da saúde-doença-intervenção. Mas também no campo das disputas micropolíticas que as disputas se tornam impactantes por ser um plano menos perceptível por operar na relação entre as pessoas.

É nesse sentido que ao retomar essas várias perspectivas se provoca o leitor para os atravessamentos dessas diferentes perspectivas no agir em saúde, no cotidiano da construção (ou destruição) do cuidado em saúde. Assim, um profissional pode operar na lógica de uma determinada perspectiva em um momento quando está numa relação com um determinado usuário e, em outro momento, operar em outra lógica. Por exemplo, mesmo que o profissional esteja numa unidade de saúde da família, orientado por uma determinada lógica de processar o cuidado de acordo como princípios da saúde da família, ele, em algumas vezes, pode ser ver numa situação operando com a lógica da perspectiva biomédica, ou campanhista. As vezes tem que dar conta de tantos números para lançar sobre a sua produção que não consegue programar algumas ações. Ou mesmo quando organiza oferta organizada a grupos populacionais considerando ciclos de vida, as vezes escapa que as pessoas podem ate estar em algum ciclo (criança, adolescente, gestante...), mas uma situação de saúde-doença-intervenção-extrapola até mesmo os ciclos.

Reconhecer que no cotidiano dos serviços as disputas micropolíticas interferem no processo de cuidado é uma abertura para construir espaços e estratégias para escapar dessas armadilhas do cotidiano do agir em saúde. Mas quais estratégias forjar para produzir um território de encontro para produção de saúde?

Retomando a reflexão sobre desenho tecnoassistencial, considerando essa disputa entre perspectitivas no cotidiano dos serviços de saúde na disputa micropolítica e na Estratégia de Saúde da Família como destacada na atual politica da Redes de Atenção à Saúde, a seguir se pretende problematizar como a ESF pode compor desenhos tecnoassistenciais de redes vivas.

\section{Pirâmide, Círculo e Rede: delineando potência em redes vivas}

Feuerwerker, Merhy (2008) ao enfocar o estudo da integralidade e humanização na atenção domiciliar analisando atendimento domiciliar em cinco 
municípios brasileiros ponderam que, mesmo em condições econômicas precárias, é possível construir integralidade no cuidado domiciliar.

A integralidade como princípio-chave para o SUS, sendo esse polissêmico e que abre novas perspectivas para produção de vida, pode ser traduzida também pelo seu compromisso de garantir atenção à saúde a todas as necessidades de saúde. Para a construção da integralidade Feuerwerker, Merhy (2008) indicam que podem ser duas as estratégias. A primeira alternativa propõe a transformação do "modelo tecnoassistencial" por meio da implementação maciça da saúde da família e a ampliação da ênfase sobre promoção à saúde. O segundo propõe a transformação da atenção tomando como central as necessidades de saúde para a construção de linhas de cuidado que atravessem todos os níveis de atenção (básica, especializada, hospitalar e urgência) e garantindo acesso e continuidade do cuidado. Por fim, ponderam que a primeira estratégia esbarra em problemas recorrentes como a fragmentação do cuidado; que muitas vezes ocorre a reprodução do pronto-atendimento na atenção básica. Já a segunda alternativa tem construído processos de cuidado que atravessam diferentes serviços da rede de saúde, sobretudo quando se asseguram modalidades inovadoras de apoio e articulação entre trabalhadores e serviço. Partindo-se dessas provocações de Feuerwerker, Merhy (2008) se pretende problematizar desenhos de pirâmide, circulo e rede viva em saúde.

Cecílio (1997) faz uma analise sobre modo de organização dos serviços de saúde associando ao desenho de pirâmide e círculo. Na primeira, a atenção primaria seria a "porta de entrada" dos usuários do sistema de saúde, com oferta promoção, prevenção e atenção integral à saúde para uma população de determinada área coberta (população adscrita) em um determinado território. Na parte intermediaria estariam os serviços de atenção secundária com ambulatórios especialidades clínicas e cirúrgicas; os serviços de apoio diagnostico; e hospitais gerais. Na parte superior da pirâmide estariam os hospitais de referência. Era uma tentativa de racionalização da prestação da assistência em saúde. Contudo, o usuário acessa o SUS de diferentes maneiras, em diferentes fluxos, "furando" essa lógica de racionalização por diversos motivos: dificuldade de recursos, pela lógica hospitalar e ambulatorial. A porta de entrada do usuário do sistema não necessariamente está na atenção básica, e também a saúde da família muitas vezes é atravessada por logicas de funcionar centrada na doença e não na 
integralidade. Por exemplo, ofertam-se serviços voltados para "grupo de hipertenso", "grupo de diabéticos", desconsiderando a integralidade da pessoa.

Pensar no processo saúde-doença-intervenção como círculo é considerar que o usuário entra por diferentes "portas", relativizando a concepção de hierarquização. Os serviços organizados em círculo leva em conta o movimento do usuário com várias entradas, entrando em serviços em acordo com os efeitos que o serviço venham a produzir em determinado caso.

Cecílio (1997) expressa que uma porta de entrada importante são os serviços de urgência e emergência, pois no Brasil foi construído na população a concepção de que tais serviços irão atender de forma imediata as necessidades das pessoas. Além do mais, ainda existe barreiras de acesso a serviços da atenção primária, afinal mesmo entendendo que houve expansão da atenção básica no país, não significa que tenha se garantido acesso a serviços de qualidade. Os hospitais também são referencias importantes para a população. Estratégico seria, segundo o referido autor, que os centros de saúde reconhecessem os grupos vulneráveis para construir estratégias de atendimento para atender essas populações. Também poderia ser qualificado enquanto "uma das" portas de entrada no sistema. Reconhecer e qualificar o acesso aos serviços de saúde e qualificar o cuidado nesses espaços é considerar os serviços como um círculo e não como pirâmide. No circulo, as entradas podem ocorrer em diferentes pontos e o processo de cuidado deve considerar essa potência do usuário em "furar" a rede instituída numa lógica de pirâmide, de serviços organizados apenas pela lófica das tecnologias duras e leve-duras.

Contudo, essa forma de organizar os serviços, como pirâmide ou círculo, são desenhos que desconsideram alguns elementos de processos micropoliticos na construção do cuidado em saúde. Admitindo que há um salto qualitativo entre a dimensão de pirâmide para a concepção de serviços em círculos, com múltiplas maneiras do usuário acessar os serviços do SUS, ainda desconsideram-se elementos que devem ser considerados no cuidado.

Para pensar em redes de saúde há um conceito para qualificar as ações e serviços, trata-se do conceito de linha de cuidado que pode ser um conceito-dispositivo para uma articulação entre serviços a partir da consideração da dimensão micropolitica 
dos serviços de saúde. Assim, a organização de linhas de cuidado de modo a articular as dimensões horizontais e verticais do processo de cuidado é potente para pensar desdenho de redes vivas transversalizando as dimensões do formal (vertical) com o indormal (horizontal) de modo a compor processos de cuidado pautados na integralidade.

É apostando nessa estratégica de redes produzida na disputa micropolítica que possivelmente conforme o desenho tecnoassistencial da perspectiva "em defesa da vida". Nesse sentido, aos apostar na luta do cotidiano dos serviços, tentando mapear/cartografar processos ao invés de estruturas, forja-se um território que potencializa transformações de redes mortas, estáticas em redes vivas, compostas por muitos olhares.

O desenho de rede a partir de Linha de Cuidado traz a conotação da produção de saúde a partir de redes macro e microinstitucionais, em processos dinâmicos, no qual está associada a imagem de um linha de produção voltada ao fluxo assistencial para atender as necessidades de um determinado beneficiário (Merhy, Cecílio, 2003; Malta, Merhy, 2010).

Para operar a Linha de Cuidado necessita de recursos/insumos que exponham as tecnologias (dura, leve-dura, leve) produzidas no processo de cuidado. Tem início na entrada do usuário "em qualquer ponto do sistema" que opere a assistência, seja na atenção domiciliar, unidade de saúde da família, unidade de urgência/emergência. A partir do local de entrada, vai sendo aberto o percurso do usuário na rede (Malta, Merhy, 2010; Malta et al., 2004; Merhy, Cecílio, 2003). Para tanto, busca-se integrar (1) o processo de trabalho em saúde, (2) demandas de organização do sistema de saúde e suas interfaces. É justamente nessas disputas desses diferentes planos que devem se voltar as diversas partes envolvidas na operação do desenho de determinada linha de cuidado.

A Linha de cuidado é uma aposta na transversalização de planos horizontais e verticais da assistência, é uma tentativa de articular tecnologias duras, leve-duras e leves para construir um cuidado integral. $\mathrm{E}$ ao trazer esses diferentes planos molar e molecular em disputa no processo de cuidado também se conforma complexa em sua expressão. Possivelmente essa dificuldade esteja na necessidade de considerar diferentes planos na produção do cuidado, que atravessam diferentes serviços e as inter-relações 
entre as pessoas que compõem o cuidado. A governabilidade da linha de cuidado está na composição das diferentes forças presentes no cuidado.

Um texto de Deleuze e Guattarri (2012) traz um debate que pode ajudar a entender a potencia dessas linhas de cuidado que busquem a integralidade na perspectuva de micropolitica, para além do modelo, mas na abertura de desenhos: o liso e o estriado. Trata-se de um texto filosófico rebuscado mas capaz de abrir outras possibilidades de pensar desenhos tecnoassistenciais. Os autores trazem o debate de modelos de diferentes concepções: modelo tecnológico, modelo musical, modelo marítimo, modelo matemático, modelo físico, modelo estético. Não se pretende aqui discorrer sobre os detalhes desses modelos, mas atentar para a desestabilização de cada um desses modelos quando se apresenta algo novo. No caso do modelo tecnológico, quando se estudam os tecidos, a princípio há um certo número de características que definem um tecido liso ou estriado. Um é mais simples, com linhas verticais outros horizontais; uns são móveis outros fixos; a montagem das fibras também difere; há o avesso e o direito. Mas eis que dentre os produtos sólidos e persceptíveis, encontram-se o feltro, que se comporta de forma diferente, não implica nenhuma distinção entre fios, nenhum entrecruzamento, é enfim um emaranhado de fibras. $O$ feltro são microfilamentos das fibras que se emaranham, de modo que o conjunto desse emaranhado não é de modo algum homogêneo.

Enfim, nesse texto os autores provocam ao apontar para a potencia da multiplicidade que extrapola movimento de categorização estruturante de modelos nas mais diferentes áreas de conhecimento, na ciência ou na arte.

Linha de cuidado é mais uma aposta entre o movimento de captura instituída e molar de intervenções na atenção em saúde (a linha com seu direcionamento) em tensionamento com o instituinte, com o molecular do cuidar (termo de dimensão ética, cuja plasticidade está nas relações entre as pessoas). Linha de cuidado pode até considerar elementos de tecnologias duras e leve-duras para compor previamente determinada linhas, daí a importância de alguns protocolos de assistência para planejar serviços, mas o prosseguir do usuário é único e processual e os diferentes serviços da rede vão se articulando a depender das necessidades de cada usuário. Linha de Cuidado como dispositivo ou agenciamento de redes vivas em saúde do modo a articular ações 
em serviços, mesmo se considerando que no cotidiano há disputas entre diferentes desenhos através das forças que atravessam o cotidiano dos serviços e ações em saúde.

Resta ponderar que essas escolhas são atravessadas por disputas de diferentes poderes e os envolvidos nessa trama podem agir de modo a produzir encontro em diferentes caminhos a serem percorridos em busca de um cuidado integral, "imagemobjetivo" por um plano ético-estético-político.

O desenho de rede, na trama das possíveis linhas, é como uma aranha que vai tecendo os caminhos conforme as pactuacoes construídas no cotidiano dos serviços de saúde, nas disputas micropolíticas. Não dá para fazer desenho simétrico na trama da rede que a aranha produz, depende do cenário e das necessidades da aranha em determinado cenário. Nesse caso, a aranha não é uma estrutura de um ente que existe em si, mas é uma composição de olhares, de multiplicidades que possam ser construídas no decorrer do trajeto do cuidado. Viver é andar a vida e por meio de linhas de cuidado pode se construir, com contribuições de diferentes perspectivas, redes vivas.

Aqui se propõe que haja a compreensão do perfil de cada serviço de uma rede de saúde, busque um dimensionamento do funcionamento desses serviços considerando elementos de territórios e intenções políticas, se pautadas ou não na integralidade do cuidado, e se apostem em linhas de cuidado mas que sejam dinâmicas. Essas linhas construídas para produção de cuidado em que várias pessoas da rede - seja gestor, trabalhador, usuário - possam construir territórios de encontros para a produção de redes vivas.

Ao iniciar o estudo de Redes em Saúde Mental considerava tal objeto articulado a organização de estrutura de serviços que deveria se articular para atuar em uma rede de assistência para atender necessidades de saúde da população. Contudo, diante de tantos processos e afetos vivenciados nessa pesquisa e também na RAC reposicionei alguns conceitos em outro plano de construção de conhecimento. Mas essa virada ocorreu diante de uma imagem: bolhas de sabão.

Um primeiro contato com a bolha de sabão e sua potência foi diante do texto “A estrutura de bolha de sabão" de Lygia Fagundes Telles. Trata-se de um conto que retrata o reencontro de uma jovem com um antigo amor que está em situação de grave 
adoecimento, à beira da morte. O tal homem é um físico e estuda a estrutura da bolha de sabão:

A estrutura da bolha de sabão, compreende? Não compreendia. Não tinha importância. Importância era o quintal de minha meninice com seus verdes canudos de mamoeiro, quando cortava os mais tenros que sopravam as bolhas maiores, mais perfeitas. Uma de cada vez. Amor calculado, porque, se me afobava, o sopro desencadeava o processo e um delírio de cachos escorriam pelo canudo e vinham rebentar na minha boca, a espuma descendo pelo queixo. Molhando o peito. Então eu jogava longe o canudo e a caneca. Pare recomeçar no outro dia, sim, as bolhas de sabão. Mas e a estrutura? $A$ estrutura - ele insistia. E seu gesto delgado de envolvimento e fuga parecia tocar mas guardava distância, cuidado, cuidadinho, ô a paciência. A paixão.

A estrutura pode ser mesmo um objeto de estudo ou mesmo um mode de organizar o pensamento. E vale a pena estudar a esrutura e ainda de uma bolha de sabão?

Pesquisando "A ciência da bolha de Sabão" na internet é possivel encontrar um vídeo do Instituto de Tecnologia Americano MIT em que uma astrofísica explica de maneira muito didática a importancia do estudo da bolha de sabão para a matemática, física e química, arquitetura e biologia. Um dos conceitos que situam a dinâmica das bolhas de sabão está no conceito de tensao superficial da água que quando misturada a substâncias presentes no sabão, desencadeiam-se o fenômeno o fenômedo da interferência presente na bolha de sabão.

$\mathrm{Na}$ água sem mistura as moléculas são iguais, a força e atraçao entre as moléculas são iguais e atravessam todas as direções. Como consequencia, a força resultante entre as moléculas de água é zero. Nada acontece. Assim, na superfície da água, há atração entre moléculas superficiais que se disponibilizam de modo a formar uma tensão superficial entre moléculas de agua em contato com o ar da atmosfera da terra, fenômeno responsável pelo não afundamento de corpos mais densos que a água. Para manter essa tensão há uma força elástica na superfície da água, formando uma espécie de "pele da água", que permite que um objeto mais pesado que a água flutue. Porém, quando se coloca detergente nessa água com um objeto flutuando, imediatamente ele afunda. Numa bolha de sabão a tensão entre molécula de água misturada a outras moléculas do sabão provocam interferencia que altera essa tensão superficial. 
As bolhas de sabão ajudaram a pensar a dinâmica de trocas gazosas que ocorrem nos pulmões, uma vez que se identificou que tensão nas paredes dos alvéolos pulmonares alterada com a presença de substâncias (sulfactantes), faz com que os alvéolos se encham e se esvaziem. $\mathrm{Na}$ arquitetura há catenóides e os helicoides, que lembram molas, também têm relacao com fenômeno das bolhas de sabão. Arquitetos ao observar experimentos com bolhas de sabão pensaram na estabilidade para alguns desenhos arquitetônicos. Todos são exmplo da potência das forças intermoleculares.

Outro fenômeno de destaque nos estudos das bolhas de sabão está o estudo das cores pela relação entre luzes e ondas. Uma onda é um aperturbação que viaja no tempo e espaço e a luz é uma onda. A depender da direção da onda assume, há uma determinada visibilidade para uma determinada cor. As cores enquanto expressão de ondas é um fenômeno de interferencia, e isso é possivel ver na dinâmica do furta-cor presente ao ocoservarmos as bolhas de sabão. E nas ondas podem acontecer interferências construtivas ou destrutivas, a depender do encontro entre diferentes ondas, aquelas na mesma direçao podem ampliar a onda e quando ondas contrárias podem anular o movimento.

Todo esse resgate rumo às bolhas foi para apontar para a importancia da interferencia para produzir movimentos, buscando relacionar tal dinâmica para a tensão micropolitica na construção de linhas de cuidado. Em outras palavras, trazer essa dimensão das interferências que atravessam a produção de redes vivas, é apontar para as disputas entre forças molar-molecular no território micropolitico. É buscar entender quais as forças atravessam o cuidado provocando determinado desenho nas relacoes micropolíticas.

Seguir usuários-guia foi se deixar atravessar pelos vários olhares buscando certa composição de forças rumo a redes vivas. Os usuários apresentados nesse estudo muito interferiram nesse processo de construção de uma linha de cuidado em que os tensionamentos de forças cfaz construir determinado caminho. E por isso a importancia de ouvir tantos e tantos pontos de vista sobre esse processo de cuidar buscando a construção para a multiplicidade da vida em seus tantos devires. Essa multiplicidade é como as cores da bolha de sabão, em tensão entre molar-molecular, no lusco-fusco, no feltro enquanto dobra entre o liso e rugoso e enquanto dobra de possibilidades do viver. 


\section{CONSIDERAÇÕES FINAIS}

A construção dessa Tese estudo foi um processo de formação ao mesmo tempo em que se construía-reconstruía o objeto estudado: redes em saúde mental. Foram muitos os atravessamentos vivenciados pela pesquisadora que deu um salto de uma visão estruturalista de modelos de saúde sobre redes de saúde para um olhar para o processual para a construção de redes vivas. E essa transformação foi no processo de encontro com tantas pessoas que se articulam em diferentes perspectivas e vão construindo redes vivas.

Esse novo olhar para redes em saúde mental, através da cartografia, foi forjando o objeto no caminhar rumo a usuários-guia. Foram tantos os afetos que construíram um outro território forjar essas visibilidades em relação a perspectivas sobre redes em saúde. A caixa de ferramentas da pesquisadora foi então ganhando outros dispositivos como caso traçador e usuário-guia, encontro enquanto método, pesquisa-interferência, redes vivas, elementos que puderam ajudar no processamento de tantos encontros e atravessamentos que esse estudo forjou ao longo do trajeto cartográfico.

Aprendi e aprendemos (sim, eu estava em multiplicidade em um grupo da Rede em avaliação Compartilhada na RAC Recife, RAC PB-PE, RAC Brasil e eu tangenciava a RAC São Paulo por também estar doutoranda da FSP/USP) que as redes vao sendo forjadas pelas pessoas no seu cotidiano. Assim como a cartografia, o processo rumo a redes vivas é atravessado por várias forças no território micropolítico no processo de saúde-doença-intervenção, entendido enquanto cuidado em saúde.

Nesse caminhar, vários conceitos ganharam outras perspectivas. A Educação Permanente em Saúde foi sendo relacionada a um "Enquadriláterio" a relação micropolitica entre diferentes pessoas que forjam a clínica do cuidado atravessada por planos da assistência, gestão, controle social e formação em saúde. Assim a Rede de Avaliação Compartilhada era como um dispositivo para estudar redes vivas foi ganhando contornos de RAC-Aranha tecendo redes vivas por interferência das várias pessoas implicadas com a produção de redes em saúde. 
Ao mesmo tempo em que se percorriam os caminhos instituídos de produção de conhecimento com diálogos de instâncias instituídas dos serviços de saúde para a realização da pesquisa, também se produziam encontros e parcerias com pessoas que estão nos serviços - profissionais residentes em saúde e profissionais gestores e trabalhadores. Os usuários-guias foram provocando nossa multiplicidade do devircuidador pois cada um dos usuários desse estudo, Pedro e Maria, foi nos ensinando a potência dos afetos para a produção de redes vivas.

Tantas vivências, atravessadas/transversalizadas por afetos, deslocou o olhar para as redes em saúde mental. São os afetos forjados no encontro, no território das disputas micropolíticas, que forjam as redes em saúde. O molar e molecular que tencionam as várias perspectivas para redes são as forças que desenham as redes, que podem estar capturados por um desenho capturado em forças de aprisionamento do "pouco mais do mesmo" ou por um devir, enquanto abertura para o novo. Foi assim que o conceito de Modelo de Atenção em Saúde foi deslocado a Desenho Tecnoassistenciais em Saúde e espera-se que esse exercício de um outro olhar para as redes provoquem os debates sobre redes em saúde no cotidiano dos serviços, promovendo diálogo entre diferentes pessoas e suas diferentes perspectivas.

Nesse estudo, o encontro foi uma aposta e o olhar cartográfico foi desarmando o olhar que se transversalizou em olho vibrátil voltado para a tensão das forças do cotidiano do cuidado em saúde. O encontro é potente para forjar tantos desenhos quanto se possa produzir para o cuidado em saúde. É no encontro que se forjam caminhos para determinada linha de cuidado e as tecnologias duras, leve-duras, leves operadas no ato de cuidar. $\mathrm{O}$ encontro forja as redes nessa disputa micropolitica de forças molares e moleculares do cuidado, tal como uma bolha de sabão, que se engendra no momento em que se inspira-expira cada ato do cuidar. 


\section{REFERÊNCIAS BIBLIOGRÁFICAS}

AMORIM, E.M. (Inter) relações entre Saúde da Família e CAPS: a perspectiva dos trabalhadores sobre cuidado a portadores de transtorno mental em Campinas-SP. S.P. [s.n.], 2008.

CECCIM, R. B; FEUERWERKER, L. C. M. O quadrilátero da Formação para a área da Saúde: ensino, gestão, atenção e controle social. Physis, Rio de Janeiro, v. 14, n.1, p. 41-65, jun. 2004.

DELEUZE, G. Espinosa: filosofia prática. São Paulo. Ed. Escuta, 2002

DELEUZE G, GUATTARI F. Mil platôs: capitalismo e esquizofrenia. Volume 1. São Paulo: Editora 34; 1995.

FEUERWERKER, L. C. M. Micropolítica e saúde: produção do cuidado, gestão e informação. Porto Alegre: Editora Rede Unida, 2014.

FRANCO, T.B; MERHY, E.E. Trabalho, Produção do Cuidado e Subjetividade em Saúde. São Paulo: Hucitec, 2013.

GOMES, M. P. C.; MERHY. E. E.(org) Pesquisadores IN-MUNDO: um estudo da produção do acesso e barreira em saúde mental. Porto Alegre: Editora Rede Unida, 2014.

LOURAU, R. Objeto e método da Análise Institucional. In: ALTOÉ, S. (Org) René Lourau: Analista institucional em tempo integral. Rio de Janeiro: Hucitec, 2004. p. 6686.

MERHY, E. E. Saúde: a cartografia do trabalho vivo. São Paulo: Hucitec, 2002.

O conhecer militante do sujeito implicado: o desafio de reconhecê-lo como saber válido. In: FRANCO, T. B. et al. (Org.) Acolher Chapecó: uma experiência de mudança do modelo assistencial, com base no processo de trabalho. São Paulo: Hucitec; Chapecó, SC: Prefeitura Municipal, 2004. p. 21-45. 
As vistas dos pontos de vista. Tensão dos programas de Saúde da Família que

pedem medidas. 2014. Disponível em:

$<$ http://189.28.128.100/dab/docs/portaldab/documentos/artigo_emerson_merhy.pdf>

Acesso em: 15 nov. 2015.

et al. Redes Vivas: multiplicidades girando as existências, sinais da rua. Implicações para a produção do cuidado e a produção do conhecimento em saúde. Divulgação em Saúde para Debate, v. 52, p. 153-164, 2014.

MOEBUS, R. L. N. Pesquisa Interferência desde Heisenberg. Diversitates International Journal, v. 7, p. 54-61, 2015.

ROLNIK, S. Cartografia sentimental: transformações contemporâneas do desejo. Porto Alegre: Sulina; Editora da UFRGS, 2006.

CATANI, J. A função do enquadre analítico no contexto hospitalar: possibilidades e limites de atuação. Revista Psicologia e Saúde, v. 5, n. 1, jan./jun., p. 25-31, 2013. ISSN: 2177-093X

ALVES, V.S. Modelo de atenção à saúde de usuários de álcool e outras drogas no contexto do Centro de Atenção Psicossocial/CAPSad. Doutorado. . Instituto de Saúde Coletiva. Universidade Federal da Bahia.

AYRES, J. R.C. M. Organizações das ações de atenção à saúde: modelos e práticas. Saúde e Sociedade. V. 18, p. 11-23. 2009.

AYRES, J.R.C.M. Epidemiologia e emancipação. São Paulo-Rio de Janeiro: HUCITEC/ABRASCO. São Paulo. 1975.

AYRES, J.R.C.M. Sujeito, subjetividade e práticas de saúde. Ciência e Saúde Coletiva. V.6, n. 1, p. 63-72, 2001.

ALTOÉ, S. História de Interseção entre Psicoterapia Institucional e Análise Institucional. In: Rodrigues, H.B.C.; Altoé, S. (org.). Saúde e Loucura. Número 8. Análise Institucional. São Pauo: HUCITEC. 2004. P. 39-64. 
AMARANTE, P.D.C. Loucos pela vida: a trajetória da reforma psiquiátrica no Brasil. 2 ed. Rio de Janeiro: Fiocruz, 1995.

AMORIM, E. M. (Inter)relações entre Saúde da Família e CAPS: a perspectiva dos trabalhadores sobre o cuidado a portadores de transtorno mental em CampinasSP. Campinas, 2008 [Mestrado - Universidade Estadual de Campinas].

BARBIER, R. Pesquisa-ação na instituição educativa. Rio de Janeiro: Zahar, 1985.

BAREMBLIT, G. Compêndio de Análise Institucional e outras correntes. Teoria e Prática. 5a Edição. Belo Horizonte: Instituto Félix Guattarri, 2002.

BARROS, R. B. Institucionalismo e dispositivo grupal. In: Rodrigues,HBC e Altoé, S. (Org.). Saúde e Loucura 8: Análise Institucional. São Paulo: Hucitec, 2004, v. 8, p. $65-78$.

BARROS, R.B. Grupo: a afirmação de um simulacro. Porto Alegre: Sulina, 2007

BATISTA E SILVA, M. B. Reforma, responsabilidade e redes: sobre o cuidado em saúde mental. Ciência e Saúde Coletiva. V. 14 , n. 1, p. 149-158, 2009.

BRAGA CAMPOS, F. C. O Modelo da Reforma Psiquiátrica Brasileira e as modelagens de São Paulo, Campinas e Santos. Campinas, 2000 [Doutorado Universidade Estadual de Campinas].

BRASIL. PORTARIA No 121, DE 25 DE JANEIRO DE 2012, que institui a Unidade de Acolhimento para pessoas com necessidades decorrentes do uso de Crack, Álcool e Outras Drogas (Unidade de Acolhimento), no componente de atenção residencial de caráter transitório da Rede de Atenção Psicossocial.2012a

BRASIL. PORTARIA No 122, DE 25 DE JANEIRO DE 2011. Define as diretrizes de organização e funcionamento das Equipes de Consultório na Rua. 2012b BRASIL. PORTARIA N 123, DE 25 DE JANEIRO DE 2012 - Define os critérios de cálculo do número máximo de equipes de Consultório na Rua por Município. 2012 c

BRASIL. PORTARIA N 130, DE 26 DE JANEIRO DE 2012. Redefine o Centro de Atenção Psicossocial de Álcool e outras Drogas 24 h (CAPS AD III) e os respectivos 
incentivos financeiros. 2012d

BRASIL. PORTARIA No 131, DE 26 DE JANEIRO DE 2012. Institui incentivo financeiro de custeio destinado aos Estados, Municípios e ao Distrito Federal para apoio ao custeio de Serviços de Atenção em Regime Residencial, incluídas as Comunidades Terapêuticas, voltados para pessoas com necessidades decorrentes do uso de álcool, crack e outras drogas, no âmbito da Rede de Atenção Psicossocial. 2012e

BRASIL. PORTARIA No 132, DE 26 DE JANEIRO DE 2012. Institui incentivo financeiro de custeio para desenvolvimento do componente Reabilitação Psicossocial da Rede de Atenção Psicossocial do Sistema Único de Saúde (SUS). 2012 f

BRASIL. Decreto $\mathbf{n}^{\mathbf{0}}$ 7.508, de 28 de junho de 2011. Regulamenta a Lei no 8.080, de 19 de setembro de 1990, para dispor sobre a organização do Sistema Único de Saúde SUS, o planejamento da saúde, a assistência à saúde e a articulação interfederativa, e dá outras providências. $2011 \mathrm{a}$

BRASIL. Portaria n. 3.088, de 23 de dezembro de 2011, republicada em 30 de dezembro de 2011. Institui e Rede de Atenção Psicossocial com a criação, ampliação e articulação de pontos de atenção à saúde para pessoas com sofrimento ou transtorno mental e com necessidades decorrentes de uso de crack, álcool e outras drogas, no âmbito do SUS. 2011b

BRASIL. Portaria, 3.089 de 23 de dezembro de 2011, republicada em 30 de dezembro de 2012. Institui o recurso financeiro fixo para os CAPS credenciados pelo Ministério da Saúde, destinado ao custeio das ações de atenção psicossocial realizadas. 2011c

BRASIL. Ministério da Saúde. Secretaria de Gestão do Trabalho e da Educação em Saúde. Departamento de Gestão da Educação na Saúde. Curso de formação de facilitadores de educação permanente em saúde: unidade de aprendizagem análise do contexto da gestão e das práticas de saúde. Rio de Janeiro: Ministério da Saúde/FIOCRUZ, 2005.

BRASIL. Ministério da Saúde. Secretaria Executiva. Secretaria de Atenção à Saúde. Legislação em Saúde Mental: 1999 - 2004. $5^{\text {a }}$ Edição ampliada. Serie E. Legislação de Saúde. Brasília/DF: Ministério da Saúde. 2004a 
BRASIL. Ministério da Saúde. Secretaria de Atenção à Saúde. Departamento de Ações Programáticas Estratégicas. Saúde Mental no SUS: os Centros de Atenção Psicossocial. Brasília: Ministério da Saúde, 2004b.

BRASIL. Lei no 10.708, de 31 de julho de 2003, que institui o auxílio-reabilitação psicossocial para pacientes acometidos de transtornos mentais egressos de internações

BRASIL. Sistema Único de Saúde. Conselho Nacional de Saúde. Comissão Organizadora da III CNSM. Relatório Final da III Conferência Nacional de Saúde Mental: Cuidar Sim, excluir não. Brasília, 11 a 15 de dezembro de 2001. Brasília: Conselho Nacional de Saúde/Ministério da Saúde, 2002.

BRASIL. PORTARIA/GM No 336 - DE 19 DE FEVEREIRO DE 2002, Estabelece CAPS I, CAPS II, CAPS III, CAPS i II e CAPS ad II.

BRASIL. Lei $\mathbf{N}^{\mathbf{0}} \mathbf{1 0 . 2 1 6}$, de 06 de abril de 2001, que dispõe sobre a proteção e os direitos das pessoas portadoras de transtornos mentais e redireciona o modelo assistencial em saúde mental.

CAMPOS, G W S; Domitti, A C; Apoio matricial e equipe de referência: metodologia para gestão do trabalho interdisciplinar em saúde. Cadernos de Saúde Pública. V. 22, n. 2, p. 399-407, fev, 2007.

CAMPOS, G. W. S. Saúde Paideia. $3^{\text {a }}$ Edição. SÃO PAULO: EDITORA HUCITEC LTDA., 2007.

CAMPOS, G. W. S.. Um método para análise e co-gestão de coletivos.. 1. ed. SÃO PAULO: EDITORA HUCITEC LTDA., 2000a. 236 p.

CAMPOS, G. W. S. Equipes de referência e apoio matricial: um ensaio sobre a organização do trabalho em saúde. Ciência e Saúde Coletiva. V. 4, n. 2, p. 393-403, 2000b.

CAMPOS, G. W. S. Considerações sobre a arte e a ciência da mudança; revolução das coisas e reforma das pessoas: o caso da saúde. In: Cecílio, L.C.O. (org) Inventando a mudança na saúde. São Paulo: HUCITEC, 1994. 
CAMPOS, G. W. S. Modelos de atenção em saúde: um modo mutante de fazer saúde. Saúde em Debate, v. 34, 1992.

CARVALHO, S.R.; FERIGATO, S.H.; BARROS, M.E.B. Conexões: Saúde Coletiva e políticas de subjetividade. São Paulo: Hucitec, 2009;

CARVAlHO, S. R.; CAMPOS, G. W. S.. Modelos de atenção à saude: a organização de Equipes de Referência na rede básica da Secretaria Municipal de Saúde de Betim, Minas Gerais. Cadernos de Saúde Pública (FIOCRUZ) ıсR, v. 16, n.2, p. 507-516, 2000.

CASTORIADIS, C. A instituição imaginária da sociedade. $2^{a}$ ed. Rio de Janeiro: Paz e Terra, 1982.

CECILIO, L.C. O. Modelos tecno-assistenciais em saúde: da pirâmide ao círculo, uma possibilidade a ser explorada. Cad. Saúde Públ., Rio de Janeiro, 13(3):469-478, jul-set, 1997.

CECÍLIO, L.C.O. (org) Inventando a mudança na saúde. São Paulo: HUCITEC, 1994.

CECCIM, R.B.; FEUERWERKER, L.C.M. Mudança na graduação das profissões de saúde sob o eixo da integralidade. Cad. Saúde Publica, v.20, n.5, p.1400-10, 2004.

DELEUZE, G.; GUATTARI, F. Mil platôs: Capitalismo e Esquizofrenia. São Paulo: Editora 34, 2000 (5 volumes).

DO EIRADO, A. Sentido e experiência no âmbito da atividade cognitiva. Rev. Psicol. (UFF), v.17, n.2, p.35-43, 2005.

DIMENSTEIN, M; ET AL. O Apoio Matricial em Unidades de Saúde da Família: experimentando inovações em saúde mental. Saúde e Sociedade. V.18, n.1, p.63-74, 2009.

FERIGATO, S.H.; CARVALHO, S. R. Pesquisa qualitativa, cartografia e saúde: conexões. Interface - Comunicação, Saúde e Educação. V.15, N o 38, p. 663-75, jul/set. 2011. 
FEUERWERKER, L. M.; MERHY, E.E. Como temos armado e efetivado nossos estudos, que fundamentalmente investigam políticas e práticas sociais de gestão e de saúde? In: Mattos, R. A.; Baptista, T.W.F. Caminhos para análise das políticas de saúde, 2011. P. 290-305. Disponível em: www.ims.uerj.br/ccaps.

FEUERWERKER, L. M.; MERHY, E.E. A contribuição da atenção domiciliar para a configuração de redes substitutivas de saúde: desinstitucionalização e transformação de práticas. Revista Panamericana de Salud Pública / Pan American Journal of Public Health, v. 24, p. 180-188, 2008.

FEUERWERKER, L. M. Modelos tecnoassistenciais, gestão e organização do trabalho em saúde: nada é indiferente no processo de luta para a consolidação do SUS. Interface: Comunicação, Saúde, Educação, v.9, n.18, p.489-506, set/dez 2005.

FIGUEIREDO, M D; ONOCKO CAMPOS, R. Saúde Mental na atenção básica de Campinas, SP: uma rede ou emaranhado? Ciência e Saúde Coletiva, V. 14, n. 1, p. 129-138, 2009.

FONSECA, T.M.G. Cartografias da arteloucura: a insurgência de um outro espaço. In: FONSECA, T.M.G.; ENGELMAN, S.; PERRONE, C.M. (Orgs.). Rizomas da reforma psiquiátrica: a difícil reconciliação. Porto Alegre: Sulina, 2007. p.141-52.

FOUCAULT, M. Problematização do sujeito: psicologia, psiquiatria, psicanálise. $3^{\mathrm{a}}$ edição. Rio de Janeiro: Forense Universitária, 2010.

FOUCAULT, M.. História da Loucura: na Idade clássica. São Paulo: perspectiva, 2009.

FOUCAULT, M. O poder psiquiátrico: curso dado no Collège de France (1973-1974. São Paulo: Martins Fontes, 2006.

FRANCISCO, GENIVALDO; ESPÍNDOLA, LUCIANA. Consultório na Rua do Recife: uma experiência de atenção ao uso abusivo de álcool e outras drogas com população em situação de rua. In: Teixeira, Mirna; Fonseca, Zilma. Saberes e práticas na atenção primária à saúde : cuidado à população em situação de rua e usuários de álcool, crack e outras drogas / organização - 1. ed. - São Paulo : Hucitec, 2015.137-146 
FRANCO, T.B. et al. (Orgs.). A produção subjetiva do cuidado: cartografias da Estratégia Saúde da Família. São Paulo: Hucitec, 2009.

FURTADO, J P; ONOCKO CAMPOS, R. Participação, produção de conhecimento e pesquisa avaliativa: a inserção de diferentes atores em uma investigação em saúde mental. Caderno de Saúde Pública. V. 24, n. 11, p. 2671-2680, Nov, 2008.

GUATTARI, F. A transversalidade In: GUATTARI, F. Revolução Molecular: Pulsações políticas do desejo. São Paulo: Brasiliense, 1987: 88-105.

HEGEL, G.W.F. A fenomenologia do espírito. In: Hegel, G.W.F. Fenomenologia do espírito; Estética: a ideia e o ideal; Estética: o belo artístico e o ideal; Introdução à História da Filosofia. São Paulo: Abril Cultural, 1980: 2-75.

HESS, R. Uma técnica de formação e intervenção: o diário institucional. In HESS, R.; SAVOYE, A. (coord.). Perspectives de I’Analyse Institutionalle. Paris: Méridiens Klincksieck. 1998. p. 119-138. (Tradução: Ana Lúcia A. Da Silva e Lucia C. Mourão. Revisão: Solange L’Abbate).

LOURAU, R. Implicação: um novo paradigma? In: ALTOÉ, S. (org). René Lourau: analista institucional em tempo integral. São Paulo: Hucitec, 2004a: 246-258.

LOURAU, R. Objeto e método da Análise Institucional. In: ALTOÉ, S. (org). René Lourau: analista institucional em tempo integral. São Paulo: Hucitec, 2004b, p. 66- 86.

LOURAU, R. Análise Institucional. Petrópolis: Vozes, 1975.

L'ABBATE; S. Análise Institucional e Intervenção: breve referência à gênese social e histórica de sua articulação na Saúde Coletiva. Mnemonise. V.8, nº1, p. 194-219, 2012.

L'ABBATE; S.O analisador dinheiro em um trabalho de grupo realizado num hospital Universitário em Campinas/São Paulo: revelando e desvelando as contradições institucionais. In: Rodrigues, H.B.C; Altoé, S. (org.). Saúde e Loucura. Volume 8. Análise Institucional. São Paulo: Hucitec, 2004, 35-57.

LUZIO, C. A; L'ABBATE, S . Atenção em Saúde Mental em municípios de pequeno e médio portes: ressonâncias da reforma psiquiátrica. Ciência e Saúde Coletiva, V 14, p. 
105-116, 2009.

LUZIO, C. A; L'ABBATE, S. A reforma psiquiátrica brasileira: aspectos históricos e técnico-assistenciais das experiências de São Paulo, Santos e Campinas. Interface: Comunicação, Saúde, Educação. V.10, n.20, p.281-98, jul/dez., 2006.

MACHADO, $\underline{\mathrm{R}}$. Foucault, a ciência e o saber. Rio de Janeiro: Jorge Zahar Editor Ltda, 2006. 202 pág.

MENDES, E. V.. As redes de atenção à saúde. Brasília: Organização Pan-Americana da Saúde, 2011. 549 p.

MERHY, E E. Um dos grandes desafios para os gestores do SUS: apostar em novos modos de fabricar os modelos de atenção. In: MERHY, E E et al. O trabalho em Saúde: olhando as experiências do SUS no cotidiano. $4^{\mathrm{a}}$ ed. São Paulo: HUCITEC. 2007. P $15^{\mathrm{a}} 36$.

MERHY, E E . Saúde: a cartografia do trabalho vivo. 1. ed. São Paulo: Editora Hucitec, 2002. v. 1. 189 p

MERHY, E E. Saúde Pública como política. 1. ed. São Paulo: Hucitec, 1992. v. 1. 220p. Disponível em: http://www.uff.br/saudecoletiva/professores/merhy/livros-03.pdf.

MONCEAU, G. Implicação, sobreimplicação e implicação profissional. Fractal Revista de Psicologia, v.20, № 1, p. 19-26, Jan/Jun. 2008.

MOURA, A.H. A Psicoterapia Institucional e o Clube dos Saberes. São Paulo: Hucitec, 2003.

MOURA, A.H. Breves Notas sobre os antecedentes da Análise Institucional. In: Boletim da novidade. São Paulo: Pulsional. Fev, p. 37-48.

MOTA, VIVIAN LEMOS. Representação social da redução de danos para profissionais que atuam pelo Programa Mais Vida da cidade do Recife. Dissertação de Mestrado. Recife, 2012.

NUNES, M; JUCÁ, V.J; VALENTIM, C.P.B. Ações de saúde mental no Programa 
Saúde da Família: confluências e dissonâncias das práticas com os princípios das reformas psiquiátrica e sanitária. Cadernos de Saúde Pública. V.23, n.10, 2375-2384.

ONOCKO-CAMPOS; R. T.; FURTADO; J. P. Entre a saúde coletiva e a saúde mental: um instrumental para avaliação da rede de Centros de Atenção Psicossocial (CAPS) do Sistema Único de Saúde. Cadernos de Saúde Pública. V 22, n. 5: 1053-1062, maio, 2006.

PAIM, J. S. Modelos de Atenção e Vigilância da Saúde. In: ROUQUAROL, M.Z. E ALMEIDA FILHO. IN: Epidemiologia e Saúde. Rio de Janeiro: MEDSI, 2003. P.567586.

PAIM, J.S. Modelos de atenção à saúde no Brasil. In: GIOVANELLA, L.; ESCOREL, S.;LOBATO, L.V.C.; NORONHA, J.C.; CARVALHO, A.I. (orgs.). Políticas e sistema de saúde no Brasil. Rio de Janeiro: Fiocruz, 2008. P.547-573.

PASSOS, E.; KASTRUP, V.; ESCÓSSIA, L. (Orgs.). Pistas do método da cartografia: pesquisa-intervenção e produção de subjetividade. Porto Alegre: Sulina, 2009.

PEZZATO, L; L'ABBATE, S. O uso de diários como ferramenta de intervenção da Análise Institucional: potencializando reflexões no cotidiano da Saúde Bucal Coletiva. Physis. Revista de Saúde Coletiva. 21(4), 2011: 1297-1314.

RECIFE. PLANO MUNICIPAL DE SAÚDE de Recife/PE 2006-2009. Recife Saudável: Inclusão Social e Qualidade no SUS (APROVADO NA 7ª CONFERÊNCIA MUNICIPAL DE SAÚDE). Aprovado na Plenária Final dessa Conferência em 16 de outubro de 2005.2 Disponível em: http://www.recife.pe.gov.br/noticias/arquivos/227.pdf. Acesso em 01 de dezembro de 2012.

RECIFE. PLANO MUNICIPAL DE SAÚDE de Recife/PE 2010-2013. Disponível em: http://www.recife.pe.gov.br/noticias/arquivos/5916.pdf. Acesso em 01 de dezembro de 2012. 
RECIFE. Secretaria de Saúde. Gerência de Atenção Básica/Gerência de Saúde Mental, Álcool e Outras Drogas. Projeto de implantação do Consultório na Rua do Município de Recife. Projeto de Fortalecimento do Componente Atenção Estratégica da Rede de Atenção Psicossocial (RAPS). 2014.

ROLNIK, S. Cartografia sentimental: transformações contemporâneas do desejo. São Paulo: Estação Liberdade, 1989.

ROLNICK, S. Cartografia sentimental. Porto Alegre: Sulina, 2007.

SILVA, SILVIO FERNANDES. (org). Redes de atenção à saúde no SUS: o pacto pela saúde e redes regionalizadas de ações e serviços de saúde. Campinas/SP: IDISA: CONASEMS, 2008.

SILVA JR, A. Modelos tecno-assistenciais em saúde. O debate no campo da Saúde Coletiva. São Paulo: HUCITEC, 1998, 13p.

TARJA Branca: a revolução que faltava. Direção: Cacau Rhoden. Produção: Estela a Renner, Marcos Nisti e Luana Lobo. Maria Farinha Filmes. 2013. (90 min). Disponível em: <https://www.youtube.com/watch?v=-xRt_7A8Jgc>.

TEIXEIRA, C.F.; SOLLA, J.P. Modelo de Atenção à saúde: promoção, vigilância e saúde da família. Salvador: Edufba, 2006.

TEIXEIRA, C.F.A mudança do modelo de atenção à saúde no SUS: desatando nós, criando laços...In: TEIXEIRA, C.F.; SOLLA, J.P. Modelo de Atenção à saúde: promoção, vigilância e saúde da família. Salvador: Edufba, 2006. P. 19 a 58.

TEIXEIRA. C.F. Modelos de Atenção voltados para a qualidade, efetividade e necessidades prioritárias de saúde. Caderno da $11^{\text {a }}$ Conferencia Nacional de Saúde. Brasília/DF, dezembro de 2000. P. 261-281. Disponível em: http://bvsms.saude.gov.br/bvs/publicacoes/11confcad.pdf. Acesso em 01 de dezembro de 2012.

TEIXEIRA, R.R. Acolhimento num serviço de saúde entendido como uma rede de conversações. In: PINHEIRO, R.; MATTOS, R.A. (Orgs.). Construção da 
integralidade: cotidiano, saberes e práticas em saúde. Rio de Janeiro: IMS-UERJAbrasco, 2003. p.89-111.

TORRE, E.H.G.; AMARANTE, P. Protagonismo e subjetividade: a construção coletiva no campo da saúde mental. Ciência e Saúde Coletiva. V.6, n.1, p.73-85, 2001. 
ANEXOS 


\section{FACULDADE DE SAÚDE PÚBLICA DA UNIVERSIDADE DE SÃO PAULO}

\section{PARECER CONSUBSTANCIADO DO CEP}

\section{DADOS DO PROJETO DE PESQUISA}

Título da Pesquisa: Rede em Saúde Mental para gestores, trabalhadores, usuários e familiares. Pesquisador: Emmanuela Mendes Amorim

Área Temática:

Versão: 1

CAAE: 49691315.6 .0000 .5421

Instituição Proponente: Faculdade de Saúde Pública da Universidade de São Paulo - FSP/USP

Patrocinador Principal: Financiamento Próprio

\section{DADOS DO PARECER}

Número do Parecer: 1.420.467

\section{Apresentação do Projeto:}

Projeto relevante e bem delineado. Caracteriza-se por metodologias qualitativas e cartografia em Unidades de Saúde da Rede de Saúde Mental no Recife.

Objetivo da Pesquisa:

Objetivo Primário: Analisar a Rede de Atenção em Saúde Mental no município de Recife na perspectiva do gestor, trabalhador, usuário e familiar.

Avaliação dos Riscos e Beneficios:

Os riscos são minimos.

Comentários e Considerações sobre a Pesquisa:

Doutorado orientado pelo Departamento de Prática

Considerações sobre os Termos de apresentação obrigatória:

TCLE adequado

Recomendações:

Conclusões ou Pendências e Lista de Inadequações:

Pela aprovação

Endereço: Av. Doutor Arnaldo, 715

Bairro: Cerqueira Cesar

CEP: $01.246-904$

UF: SP Município: SAO PAULO

Telefone: (11)3061-7779 Fax: (11)3061-7779

E-mail: coep@fsp.usp.br

Página 01 de 02 


\section{FACULDADE DE SAÚDE PÚBLICA DA UNIVERSIDADE DE SÃO PAULO}

Continuação do Parecer. 1.420.467

Considerações Finais a critério do CEP:

Este parecer foi elaborado baseado nos documentos abaixo relacionados:

\begin{tabular}{|c|c|c|c|c|}
\hline Tipo Documento & Arquivo & Postagem & Autor & Situação \\
\hline $\begin{array}{l}\text { Informações Básicas } \\
\text { do Projeto }\end{array}$ & $\begin{array}{l}\text { PB_INFORMAÇŐES_BÁSICAS_DO_P } \\
\text { ROJETO 520290.pdf }\end{array}$ & $\begin{array}{c}29 / 09 / 2015 \\
14: 31: 41\end{array}$ & & Aceito \\
\hline Folha de Rosto & Folha_CEP_FSP_Redes.docx & $\begin{array}{c}29 / 09 / 2015 \\
14: 30: 11\end{array}$ & $\begin{array}{l}\text { Emmanuela Mendes } \\
\text { Amorim }\end{array}$ & Aceito \\
\hline $\begin{array}{l}\text { Projeto Detalhado / } \\
\text { Brochura } \\
\text { Investigador }\end{array}$ & PROJETO.pdf & $\begin{array}{c}17 / 09 / 2015 \\
14: 06: 52\end{array}$ & $\begin{array}{l}\text { Emmanuela Mendes } \\
\text { Amorim }\end{array}$ & Aceito \\
\hline $\begin{array}{l}\text { TCLE / Termos de } \\
\text { Assentimento / } \\
\text { Justificativa de } \\
\text { Ausência }\end{array}$ & TCLE_doutorado_manu.docx & $\begin{array}{c}17 / 09 / 2015 \\
14: 04: 50\end{array}$ & $\begin{array}{l}\text { Emmanuela Mendes } \\
\text { Amorim }\end{array}$ & Aceito \\
\hline
\end{tabular}

Situação do Parecer:

Aprovado

Necessita Apreciação da CONEP:

Não

SAO PAULO, 23 de Fevereiro de 2016

Assinado por:

Maria Regina Alves Cardoso

(Coordenador)

Endereço: Av. Doutor Arnaldo, 715

Bairro: Cerqueira Cesar

UF: SP

Município: SAO PAULO

CEP: $01.246-904$

Telefone: (11)3061-7779

Fax: (11)3061-7779

E-mail: coep@fsp.usp.br 